Pedro de Figueiredo Ferraz Pereira Leite

\title{
Contribuição crítica à teoria da motivação das decisões judiciais
}

\author{
Dissertação de mestrado \\ Área de concentração: Direito Processual \\ Professor Orientador: Paulo Henrique dos Santos Lucon
}

Faculdade de Direito da Universidade de São Paulo

São Paulo

2014 
TERMO DE APROVAÇÃo

Pedro de Figueiredo Ferraz Pereira Leite

\section{Contribuição crítica à teoria da motivação das decisões judiciais}

Dissertação de mestrado aprovada como requisito parcial para a obtenção do grau de Mestre em Direito Processual Civil no Programa de Pós-Graduação stricto sensu da Faculdade de Direito da Universidade de São Paulo, pela seguinte banca examinadora:

Orientador: $\quad$ Professor Doutor Paulo Henrique dos Santos Lucon

Membros: $\quad$ Professor

Professor

São Paulo, de de 2014 


\section{RESUMO}

Pereira LeITe, Pedro de Figueiredo Ferraz, Contribuição crítica à teoria da motivação da decisão judicial, Dissertação (Mestrado) - Faculdade de Direito da Universidade de São Paulo, 2014.

O presente trabalho se estrutura em torno da resposta a duas questões: "O que é uma decisão motivada?" e "Quais as consequências de uma decisão imotivada?". Nesta perspectiva, partese da definição da motivação como um discurso cuja função é a de justificar racionalmente a decisão judicial. Esta justificativa racional tem funções endoprocessuais e extraprocessuais. Dentre as funções extraprocessuais, destaca-se a de conferir legitimidade à atuação jurisdicional no Estado Democrático de Direito. Ainda no âmbito da norma constitucional que impõe ao juiz o dever de fundamentar suas decisões, demonstra-se que ela se estrutura sob a forma de regra, nos termos da teoria dos princípios de ALEXY, com a consequência de que os limites para a caracterização de uma decisão como motivada são rígidos. Passa-se, então, à construção de um modelo teórico de estrutura da motivação sob a ótica funcional. $\mathrm{Na}$ construção desse modelo, demonstra-se que a estrutura e conteúdo da motivação no caso concreto dependem da interação de um modelo mínimo de justificação adequada, um modelo intermediário delimitado pelo contraditório e um limite máximo delimitado pela linguagem. A partir desse modelo interativo exploram-se as consequências dos vícios de motivação segundo uma teoria das nulidades dos atos processuais e, assim, conclui-se que a motivação só será considerada inexistente em caso de omissão gráfica e que qualquer vício de fundamentação é uma atipicidade relevante que deve ser nulificada. 


\begin{abstract}
The present work is structured around answering two questions: "What is a motivated decision?" and "What are the consequences of an unjustified decision?". In this perspective, we start from the definition of motivation as a speech whose function is to rationally justify the decision. This rational justification has legal and constitutional functions. Among the constitutional functions one that stands out is to legitimate the courts' role under in the rule of law. Also as part of the constitutional rule determining courts to motivate their decisions, it is shown that it is structured in the form of a rule in accordance with the principles theory of ALEXY, resulting that the limits for the characterization of a motivated decision are rigid. Then it is possible to create a theoretical model of the structure of motivation from a functional perspective. When building this model, we demonstrate that the structure and content of motivation depends on the interaction of a minimal model of proper justification, an intermediate model bounded by the adversarial principle, and another model, bigger than the others, defined by the language. From this interactive model it becomes possible to explore he consequences of the defects of motivation according to a nullity of procedural acts theory and thus it is concluded that motivation won't be considered existent only in case of graphical omission and that any defective reasoning must be nullified .
\end{abstract}




\section{Agradecimentos}

Ao meu orientador, Professor Paulo Henrique dos Santos Lucon, acima de tudo pela oportunidade que me deu ao acreditar naquele jovem recém-saído da graduação, mas também pelas lições sobre Processo Civil desde a Graduação; pela oportunidade que tive de auxiliá-lo nas atividades docentes; pela oportunidade profissional que me deu; e pela orientação que me deu ao longo dos últimos três anos.

Ao mencionar a oportunidade que tive de auxiliar em atividades docentes, não posso me esquecer do Professor Carlos Alberto Carmona, a quem também auxiliei e de quem tive o prazer de ser aluno por quatro anos durante a Graduação e orientando no Trabalho de Conclusão de Curso.

Aos colegas nas atividades de monitoria, Ricardo de CARvalho Aprigliano, Carlos Eduardo Stefen Elias, mateus Aimoré Carreteiro, lilian Patrus Marques e FERNANDA DE GOUVÊA LEÃO, que fizeram daquelas manhãs momentos de alegria e companheirismo.

Aos Professores Heitor Vitor Mendonça Sica e Maurício Zanoide de Moraes pelas valiosíssimas contribuições que fizeram durante a Banca de Qualificação.

Além do Professor LuCon, agradeço também aos seus sócios, JoÃo PAUlo HeCKER DA SiLVA e RONALDO VASCONCELOS pela oportunidade trabalhar no LUCON ADVOGADOS, onde evolui muito como advogado devido a confiança que em mim depositaram e onde fiz grandes amigos. Dentre esses amigos, não posso deixar de mencionar os companheiros de sala, Marcos Vinícius Pinto, Rafael Alfredi de Matos e Édson Alves da Silva, pelas discussões jurídicas sempre de alto nível, mas acima de tudo pela intensa amizade. Agradeço ainda ao amigo sem o qual eu não teria entregado essa dissertação, RODRIGO CABRAL FRANCO. 
Dentre os colegas da época de LUCON ADVOGAdos, dois merecem um agradecimento especial. O primeiro, Marcel CARvalho Engholm CARdoso, pela amizade e companheirismo que continuarão na nova etapa de nossas carreiras profissionais, recéminiciada. O segundo, GuILHERME RECENA COSTA, pela amizade e pelas intensas e constantes contribuições à minha dissertação.

Aos meus pais, Leandro Pereira leite e Lúcia Maria de Figueiredo Ferraz Pereira LEITE por todo o carinho, atenção e amor que sempre me dedicaram, por todas as oportunidades que me propiciaram, inclusive a de me apaixonar pelo Direito, mas acima de tudo pela paciência que tiveram e ajuda que deram nesses anos dedicados ao Mestrado.

Às minhas avós, Maria Lúcia de Souza Ferraz e Maria Madalena Bassanta Pereira LEITE que, como todas as avós, se orgulhariam de tudo que eu fizesse, na esperança de lhes dar um bom motivo para se orgulhar.

Ao meu grande amor, companheira para toda a vida, NAJLA MARIA LOUREIRO DIB por todo o amor, carinho, ajuda e compreensão nesses últimos três anos.

Acima de tudo, ao meu irmão, Paulo de Figueiredo Ferraz Pereira Leite. Sou dos poucos sortudos que podem dizer que seu irmão é seu melhor amigo. Não existem palavras para descrever o tanto que ele me ajudou na realização desta dissertação, seja no constante e enriquecedor debate de ideias, seja nas diversas revisões. $O$ principal motivo do agradecimento, no entanto, não é a contribuição absolutamente essencial e necessária para a realização deste trabalho, mas o fato de estar ao meu lado toda a vida. 
"Soube, ou meramente sentiu, que retomava por fim seu destino e que seu destino estava se cumprindo. Também isso o conformou. Não só viu sua coragem, que refletia com a luz no punhalzinho sereno; viu o grande final, a morte esplendorosa. Já em 27 Gauna entrevira o outro lado. Recordou-o fantasticamente: só assim é possível recordar a própria morte. Encontrou-se de novo no sonho dos heróis, que começou na noite anterior, no depósito do Manco Araujo. Compreendeu para quem estava estendido o caminho de tapete vermelho e avançou resolutamente". (ADOLFO BIOY CASARES, O sonho dos heróis) 


\section{ÍNDICE}

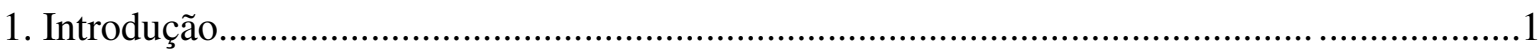

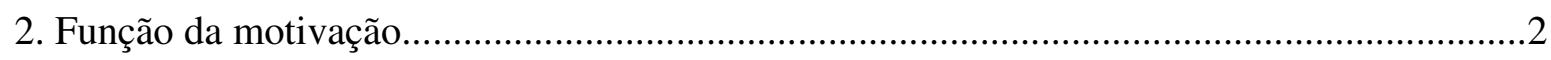

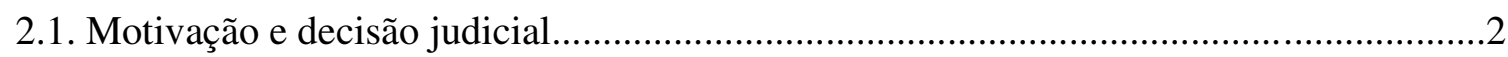

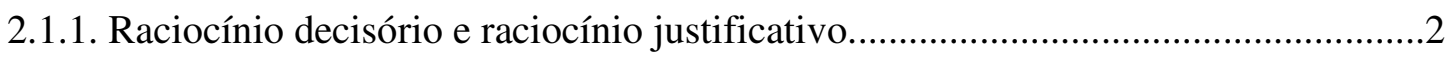

2.1.1.1. Motivação e decisão como signos.................................................................

2.1.1.2. Motivação como signo natural capaz de fornecer indícios das "razões reais"

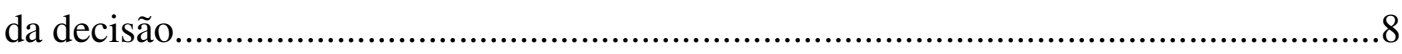

2.1.1.3. Discurso demonstrativo $\mathrm{X}$ discurso justificativo..............................................

2.1.1.4. Significado da motivação.................................................................................. 10

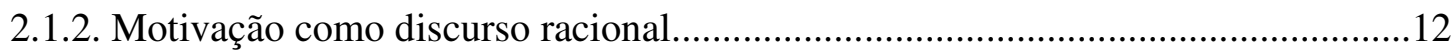

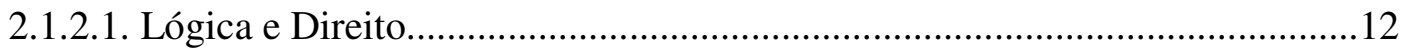

2.1.2.2. Críticas ao caráter lógico e racional da decisão judicial e da motivação e

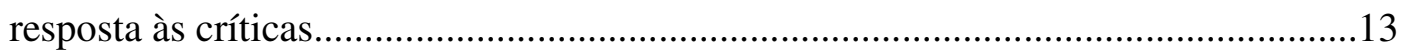

2.1.2.3. Uso da lógica no raciocínio decisório e no raciocínio justificativo.................15

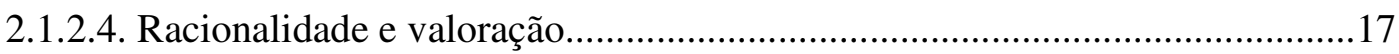

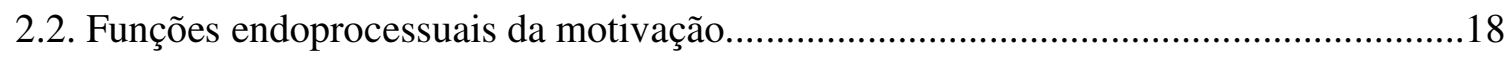

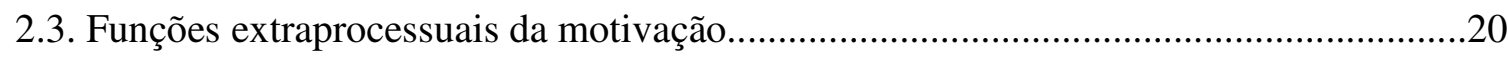

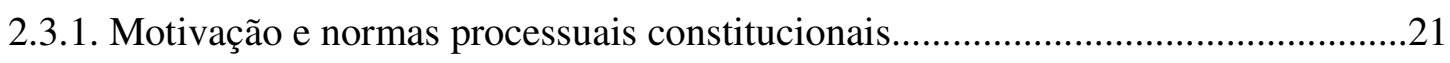

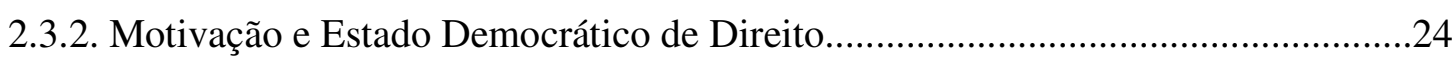

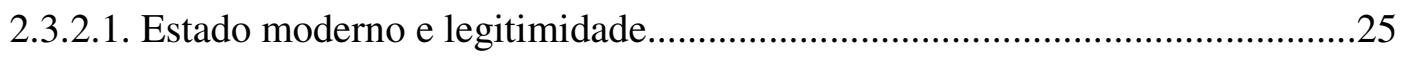

2.3.2.2. Desconcentração do núcleo de tomada de decisões políticas.........................27

2.3.2.3. Motivação e democracia deliberativa...........................................................29

2.3.2.4. Motivação e controle democrático da decisão................................................30

2.3.2.5. Controle democrático da decisão e conteúdo da motivação.............................32

2.3.3. Dever de motivação como regra constitucional......................................................33

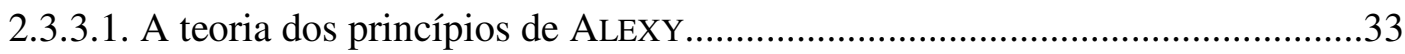

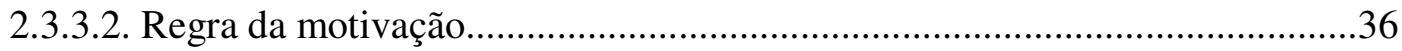

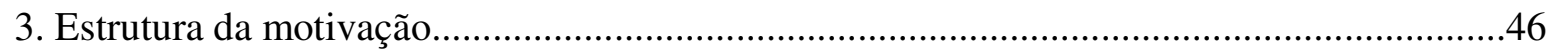


3.1. Estrutura e função da motivação .46

3.2. Teorias sobre a estrutura do raciocínio decisório e raciocínio justificativo.....................48

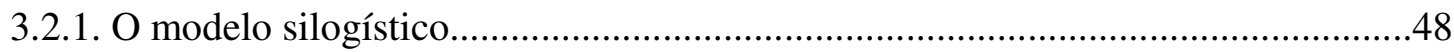

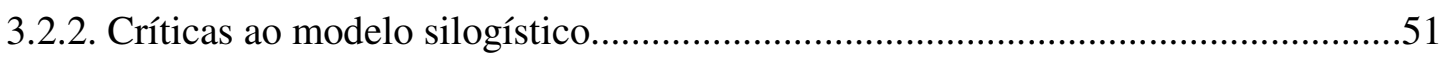

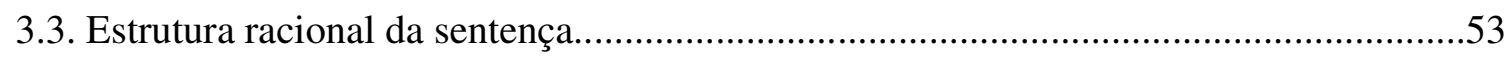

3.4. Raciocínio do juiz como um conjunto estruturado de escolhas.....................................54

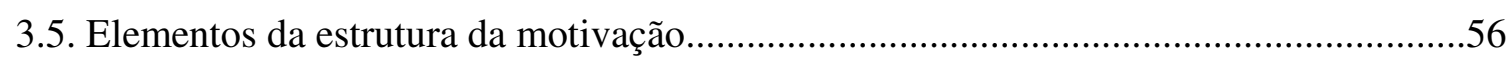

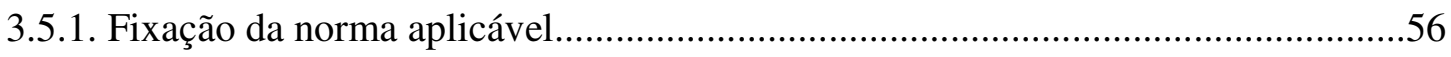

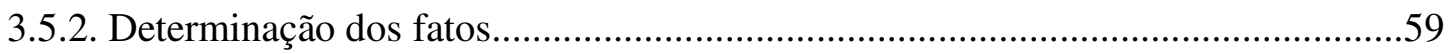

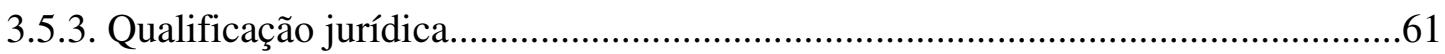

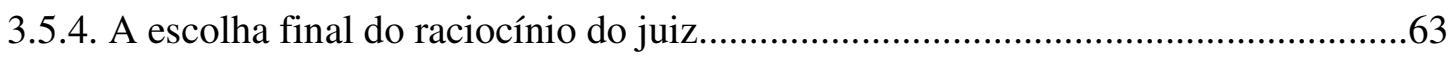

3.6. Estrutura da motivação conforme sua função justificativa.............................................65

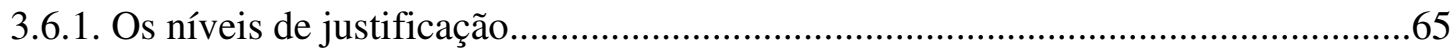

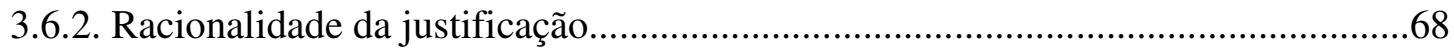

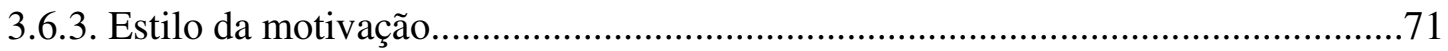

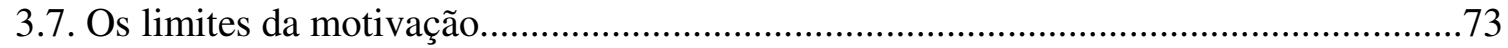

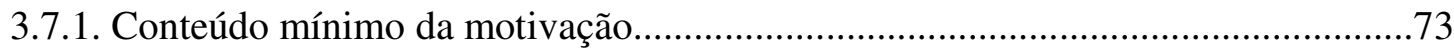

3.7.2. Conteúdo da motivação definido pelo contraditório...............................................74

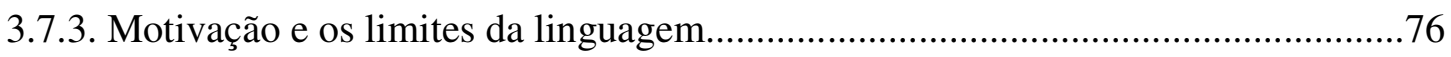

3.7.4. Critério interativo de suficiência da motivação......................................................77

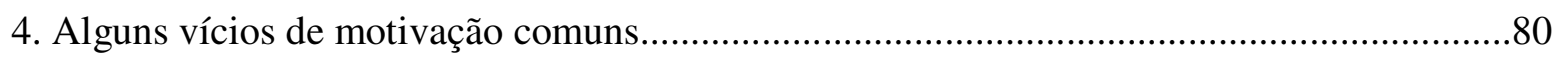

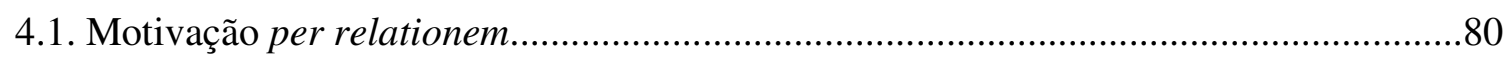

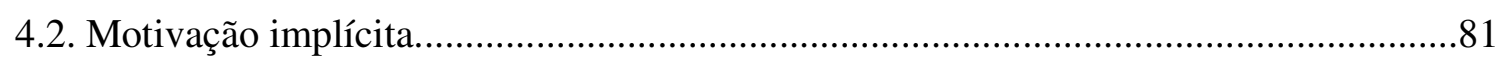

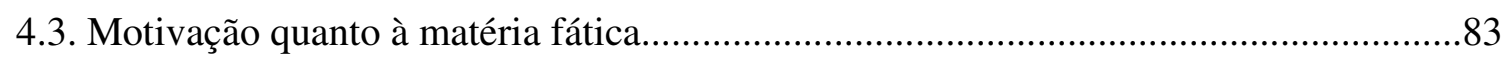

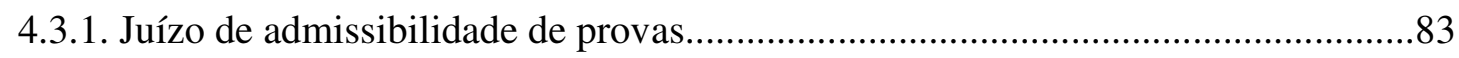

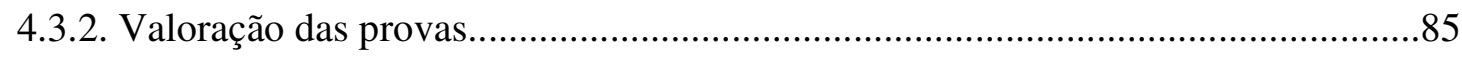

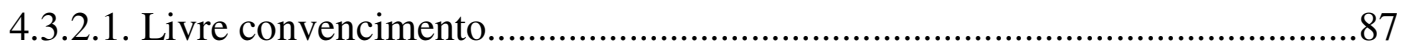

4.3.2.1.1. Prevalência do livre convencimento racional.........................................90

4.3.2.1.2. Teoria das "ilhas" de valoração legal da prova dentro de um "mar" de

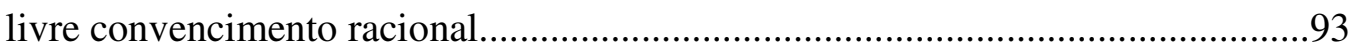

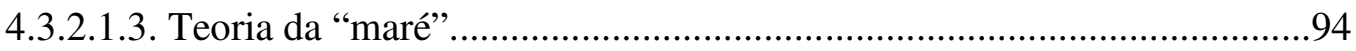




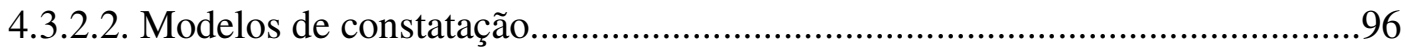

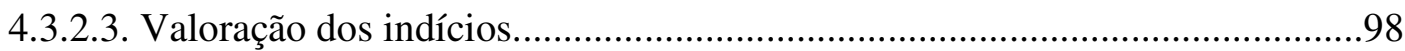

4.3.2.3.1. Qual espécie de inferência?...................................................................100

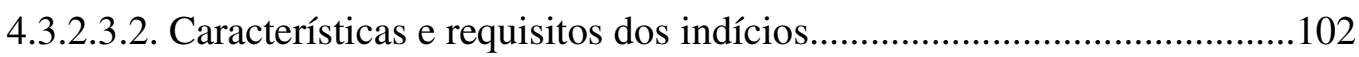

4.3.2.3.3. Fato indiciante como fato certo............................................................ 102

4.3.2.3.4. Conceituação da gravidade, precisão e concordância............................103

4.3.2.3.5. Interação de gravidade, precisão e concordância...................................105

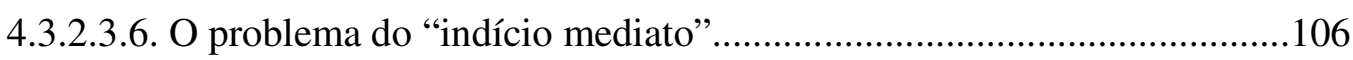

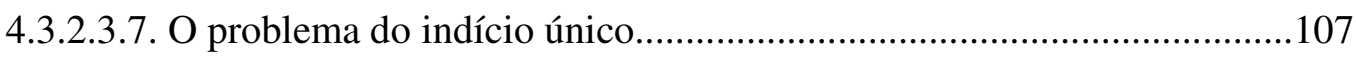

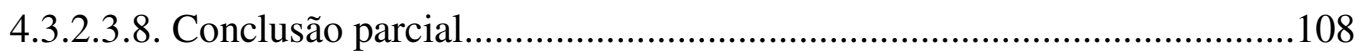

4.3.2.4. Valoração da "nova" prova pericial.................................................................. 108

4.3.2.4.1. Valoração da perícia e valoração dos resultados da perícia científica..111

4.3.2.4.2. Objeto da perícia e objeto da prova...................................................115

4.3.2.4.3. Perícia e modelos de constatação............................................................116

4.3.2.4.4. Conclusão parcial................................................................................117

5. A motivação na teoria das nulidades dos atos processuais.................................................118

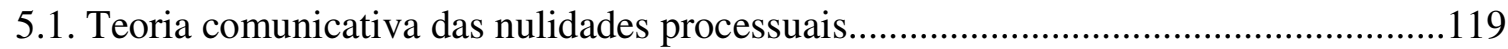

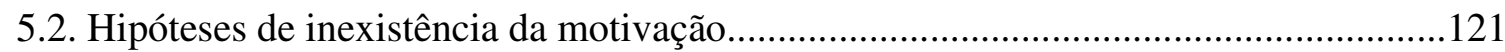

5.3. Configuração e consequências da motivação nula........................................................122

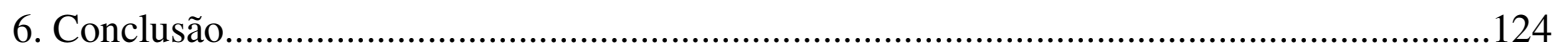

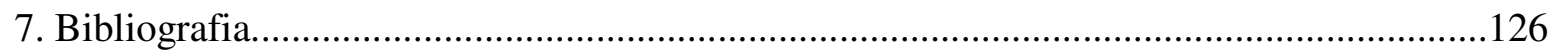




\section{INTRODUÇ̃̃̃o}

Esta dissertação se propõe a responder duas grandes perguntas que, por sua vez, desdobram-se em diversas outras questões logicamente subordinadas. A primeira pergunta é: “O que é uma decisão motivada?”, ou seja, quais são os requisitos para que se possa caracterizar uma decisão como motivada. A segunda pergunta é: "Quais as consequências de uma decisão imotivada?", ou seja, como enquadrar a decisão jurisdicional imotivada dentro de uma teoria do ato jurídico - e, mais especificamente, dentro de uma teoria das nulidades dos atos processuais.

Para responder à primeira pergunta, será necessário analisar: (i) a função da motivação o que será abordado no Capítulo 2. A partir da função da motivação, será possível definir sua estrutrura e os critérios para que se possa considerar adequada a motivação — objeto do Capítulo 3. Com base nesses critérios, analisar-se-á, no Capítulo 4 algumas situações comuns na jurisprudência em que é possível cogitar de defeitos na motivação, a fim de demonstrar e testar o modelo contruído no Capítulo anterior.

Determinados os critérios capazes de diferenciar uma decisão motivada de uma decisão imotivada torna-se necessário determinar as consequências jurídicas da ausência ou do defeito de motivação. Esse exame será feito de acordo com a teoria das nulidades dos atos processuais no Capítulo 5. Por fim, com base nas conclusões dessa teoria será possível determinar os efeitos jurídicos da ausência ou insuficiência de motivação da decisão judicial. 


\section{FUNÇÃO DA MOTIVAÇÃo}

Para determinar o conteúdo da motivação é necessário entender que papel a fundamentação das decisões exerce em três contextos distintos. O primeiro desses contextos é o da própria decisão da qual faz parte e será objeto de análise do item 2.1. Definido o papel da motivação nesse contexto, é necessário entender a função endoprocessual da motivação, analisada no item 2.2. Não é possível, no entanto, considerar esgotada a análise da função da motivação sem que se entenda as funções que ela desempenha fora do processo, que decorrem da Constituição e de considerações sobre a organização do Estado. Essas considerações serão objeto do item 2.3

\subsection{Motivação e decisão judicial}

Para entender a relação entre motivação e decisão judicial é necessário, em um primeiro momento, distinguir dois raciocínios, nomeadamente decisório e justificativo. A análise dessa distinção será objeto do item 2.1.1. Com base nessa distinção, será possível definir a motivação como a justificação racional da decisão. Os motivos e consequências dessa definição serão objeto do item 2.1.2.

\subsubsection{Raciocínio decisório e raciocínio justificativo}

Uma das primeiras premissas necessárias para entender adequadamente a motivação é distinguir o raciocínio decisório do raciocínio justificativo. Essa distinção não significa, no entanto, que é possível compreender a motivação sem qualquer referência à decisão judicial. Para compreender a estrutura da motivação, é necessário entender a estrutura do raciocínio decisório. ${ }^{1}$

A diferenciação entre raciocínio decisório e raciocímio justificativo começa da comprensão da decisão e da motivação como signos (item 2.1.1.1), de onde se extrai a possibilidade de interpretar a motivação como "sintoma" das "razões reais da decisão" (item 2.1.1.2). Da caracterização da decisão e da motivação como signos, é possível estabelecer claramente a

\footnotetext{
${ }^{1}$ TARUFFO, Michele, La motivazione della sentenza civile, Padova, CEDAM, 1975, p. 13.
} 
distinção entre raciocínio decisório e raciocínio justificativo (item 2.1.1.3) e o significado da motivação como signo (item 2.1.1.4).

\subsubsection{Motivação e decisão como signos}

A distinção entre motivação e decisão - mais precisamente, a rejeição da ideia de que a motivação deve refletir o processo decisório ${ }^{2}$ - começa a ser delineada da definição segundo a qual a motivação, como a sentença, é um discurso ${ }^{3}$, assim entendido como um conjunto de proposições ligadas umas às outras e inseridas em um contexto - discursivo — identificável autonomamente ${ }^{4}$. Sendo discursos, a decisão judicial e sua motivação devem ser entendidas como fenômenos linguísticos, compostos de proposições, que no caso da decisão e da motivação, exprimem juízos sobre algo — ou seja, estabelecem uma conexão entre um sujeito e um predicado.

Uma vez que a motivação é um conjunto de entidades linguísticas, ela pode e deve ser analisada sob o ponto de vista da semiologia ${ }^{5}$, o que faz com que se tornem necessárias algumas definições. Segundo a teoria semiótica estrutural ${ }^{6}$ signo é a união entre significante - entidade linguística que constitui o elemento material do processo de comunicação - e significado - o conteúdo da significação. O signo é, portanto, o meio pelo qual ocorre o processo de significação.

A sentença - e, portanto, a motivação e as proposições que a compõem - exerce uma função comunicativa e, por isso, é apta a ser caracterizada como signo. Para que a sentença possa ser considerada um signo, é necessário que haja um sujeito que interpreta um objeto — o significante —, atribuindo-lhe significado, e esse signo seja decodificado de acordo com critérios de interpretação, individuando esse significado. A sentença, como signo, comunica a decisão, ao passo que a motivação, como signo, comunica as razões da decisão. ${ }^{7}$

\footnotetext{
${ }^{2}$ Defendida, por exemplo em Botelho De Mesquista, José Ignacio, Autoridade da coisa julgada e a imutabilidade da motivação da sentença, São Paulo, Salesianas, 1963, p. 45

${ }^{3}$ TUCCI, José Rogério Cruz e, A motivação da sentença no processo civil, São Paulo, Saraiva, 1987, p. 13.

${ }^{4}$ TARUFFO considera, convencionalmente, que a proposição é o elemento atômico (isto é, que não pode ser dividido) da sentença, embora saiba que, linguisticamente, a proposição também é um conjunto de outros elementos. La motivazione della sentenza civile, cit. n. 1, p. 34.

${ }^{5}$ TARUFFO, Michele, La motivazione della sentenza civile, cit. $n$. 1, pp. 30, 33, 35-36, 38.

${ }^{6}$ DE SAUSSURE, Ferdinand, Cours de linguistique générale, $3^{\mathrm{a}}$ ed., Paris, Payot, 1964, passim.

${ }^{7}$ TARUFFO, Michele, La motivazione della sentenza civile, cit. $n$. 1, pp. 40-42.
} 
A sentença pode ser considerada signo em quatro situações: a) quando as partes interpretam a sentença; b), quando o juiz a quem se dirige o recurso a interpreta; c) quando o público em geral a interpreta; e d) quando um jurista a interpreta.

Quando as partes interpretam a sentença, tomam como ponto de comparação os pedidos por elas realizados e podem utilizar um ou mais entre vários códigos, entre os quais pode se destacar: o código léxico utilizado para decifrar a linguagem comum; o código léxico utilizado para decifrar a linguagem técnica jurídica; o código de decifração conceitual — conjunto de normas, dogmas, noções e conceitos jurídicos —; o código de decifração fático - alegações de fato, inferências probatórias e resultado de prova —; o código de decifração jurídico - pedidos, exceções e objeções, nexo de prejudicialidade ou conexão entre as questões jurídicas e causa de pedir; e o código misto parcial - que permite a interpretação do dispositivo de acordo com a motivação.

O juiz a quem se dirige o recurso interpreta a sentença utilizando-se dos mesmos códigos mas toma como ponto de comparação as alegações realizadas em sede de recurso.

O público em geral não tem acesso aos mesmos códigos utilizados pelas partes ou pelo juiz para interpretar a sentença, não só porque não sabe utilizar esses códigos, mas também porque vê a sentença como algo mais do que uma solução jurídica para a lide. O público em geral vê a sentença como escolha ético-política, que deve ser interpretada de acordo com os valores prevalentes em determinada comunidade sócio-política localizada temporal e geograficamente. ${ }^{8}$

O jurista pode, a seu arbítrio e de acordo com a função do estudo que conduz, interpretar a sentença de maneira análoga às partes ou ao juiz (isto é, de maneira técnico-jurídica) ou de

\footnotetext{
${ }^{8} \mathrm{O}$ fato de o público em geral não ser capaz de decodificar a sentença com base em códigos que exigem conhecimento técnico faz com que muitas vezes o público tenha acesso a uma versão já decodificada muitas vezes de maneira incompleta ou tendenciosa - da sentença. É o que ocorre toda vez que os meios de comunicação de grande impacto noticiam sobre decisões jurídicas (veja-se, no Brasil o caso Mensalão Ação Penal no 470 - ou o caso Isabela Nardoni). A impossibilidade de o público em geral ser capaz de decodificar a sentença, por sua vez, decorre da utilização de linguagem técnico-jurídica na sentença. Essa utilização é, de um lado, uma necessidade operacional, porque essa linguagem facilita a compreensão da sentença pelas partes e, consequentemente, sua eventual impugnação e/ou execução, duas das funções da motivação (infra 2.2). De outro lado, a utilização de linguagem técnico-jurídica acaba por dificultar o atingimento de outra das funções da motivação que é justificação da atuação estatal para o povo.
} 
maneira análoga ao público em geral (nesse caso, pode recorrer a outras ciências diferentes da jurídica).

Para compreender a sentença como signo é necessário mais um esclarecimento. Os signos dividem-se em signos em sentido próprio e sintomas — ou, na terminologia de Santo Agostinho, signos naturais e signos institucionais. O critério dessa distinção é a presença, somente nos signos institucionais, da vontade de significar algo. $\mathrm{O}$ signo natural transforma-se, ex post, em signo, no momento em que um observador atribui-lhe um significado utilizando de critérios interpretativos adequados.

Assim, por exemplo, um rastro é um signo natural, que significa que alguém ou algum animal passou por aquele lugar recentemente. No momento em que um observador atribui a esse rastro o significado da passagem de alguém ou algo pelo lugar, o signo natural se transforma em signo. Uma palavra, por sua vez, é um signo institucional, que foi criado com a intenção de significar algo. Por mais que um observador não atribua significado a palavra, ela já foi criada para significar, ao contrário do que ocorre com o rastro.

Os signos institucionais resultam de convenções sociais e, por isso, ao interpretar um signo, ou um conjunto deles, devem ser levados em conta os cânones convencionais empregados pelo emitente do discurso. No caso da sentença, isso significa que o intérprete deve levar em conta as regras do discurso comum e do discurso técnico-jurídico, além de outros fatores, como os pedidos das partes. ${ }^{9}$

Pode ser que o significado que se quis exprimir não coincida com o significado convencionalmente construído a partir ao signo, seja por um uso incorreto das regras linguísticas, seja por conta da polivalência e da vaguidade ${ }^{10}$ típicas da linguagem humana. ${ }^{11}$ Nesse caso, considerando a irrelevância da vontade do juiz na interpretação da sentença, deve ser interpretado o significado convencional, não aquele que se quis exprimir.

\footnotetext{
${ }^{9}$ TARUFFO, Michele, La motivazione della sentenza civile, cit. $n$. 1, pp. 42-46, 49, 51.

${ }^{10}$ GENARO CARRIÓ afirma que a vaguidade, imprecisão do significado de uma expressão, atinge a todos os termos linguísticos, no que denomina a vagueza potencial dos termos, decorrente da textura aberta da linguagem, conforme CARRIÓ, Genaro, Notas sobre Derecho y Lenguaje, Buenos Aires, Abeledo-Perrot, 1990 , p. 35.

${ }^{11}$ PORSCHER, Ralf, Ambiguity and Vagueness in Legal Interpretation in Oxford Handbook on Language and Law, SOlAN, Lawrence e TIERSMA, Peter (orgs.), Oxford, Oxford University Press, 2011, passim.
} 
Pode ocorrer, também, que existam diferenças entre o significado expresso na sentença e aquele resultante da interpretação por um determinado sujeito, em virtude das diferentes possibilidades interpretativas (que, por sua vez, decorrem dos diferentes cânones interpretativos que podem ser utilizados). A adequação do critério interpretativo utilizado para descobrir o significado de um signo natural é avaliada a posteriori, já que depende da eficácia da interpretação segundo esse critério.

A utilização dos critérios interpretativos, por sua vez depende da maneira como se atribui significado à sentença — isto é, se essa é tomada como signo natural ou institucional. Quando as partes ou juiz de instância superior interpretam a sentença, interpretam-na como signo em sentido próprio, ao passo que, quando o público a interpreta, interpreta-a como signo natural, (e.g. como indício das orientações político-ideológicas do juiz). A interpretação da sentença pelos juristas pode tomá-la seja como signo institucional, seja como signo natural, a depender da intenção do intérprete. ${ }^{12}$

Ao interpretar a motivação da sentença como signo institucional adquire extrema importância a utilização de cânones interpretativos adequados o que, nesse caso específico, implica a necessidade de interpretar a motivação de acordo com a sua função no discurso no qual se insere, a sentença. Essa função é fornecer uma justificação racional da decisão ${ }^{13}$. A necessidade de levar em conta a função da motivação ao interpretá-la como signo institucional decorre do fato de que a função de um discurso influencia no estilo, na estrutura lógica e no próprio conteúdo do discurso, que se orienta de acordo com essa função ${ }^{14}$ (como se verá no Capítulo 3).

É possível criticar-se uma abordagem exclusivamente linguística e semiológica em um estudo sobre a motivação da sentença, já que esse é um fenômeno jurídico. Essa crítica estaria correta até o ponto no qual aponta a necessidade de encarar o fenômeno também sobre a ótica jurídica. Além desse ponto - isto é, se essa crítica significar que a motivação da sentença só pode ser estudada sob a ótica jurídica —, a crítica deve ser rejeitada porque a análise exclusivamente jurídica sobre o fenômeno da motivação só resulta em definições

\footnotetext{
${ }^{12}$ TARUFFO, Michele, La motivazione della sentenza civile, cit. $n .1$, pp. 50-51, 54.

${ }^{13}$ TARUFFo, Michele, La motivazione della sentenza civile, cit. $n$. 1 , p. 55; TUCCI, José Rogério Cruz e, $A$ motivação da sentença no processo civil, cit. n. 3, p. 15.

${ }^{14}$ TARUFFo, Michele, La motivazione della sentenza civile, cit. n. 1, pp. 55-56.
} 
insuficientes ou tautológicas (e.g. a motivação deve ser suficiente; a motivação reflete o iter lógico do raciocínio judicial).

A motivação, assim deve ser encarada tanto como fenômeno linguístico quanto como fenômeno jurídico. Isso significa que deve se levar em conta que a motivação é um discurso cujo emitente é o juiz e que tem um papel definido na função que cabe ao juiz a prolação de uma decisão em uma lide. Esse contexto no qual se insere a motivação demanda a atenção às normas que determinam as características da motivação como fenômeno processual.

A importância de encarar a motivação sob o ângulo do Direito não abre uma terceira possibilidade de interpretação do signo motivação, mas orienta a escolha de qual deve ser a perspectiva correta sob a qual deve ser encarada a motivação. Isso não significa rejeitar todas as perspectivas que não sejam jurídicas, mas rejeitar aquelas que não sirvam para resolver esse problema, que é jurídico.

A dificuldade de encarar a motivação sob uma perspectiva exclusivamente jurídica decorre do fato de que as normas que atinem à motivação são incapazes de definir suas caraterísticas mais importantes de maneira satisfatória. Dentre essas características destacam-se o conteúdo mínimo necessário para ser possível dizer que uma sentença é motivada e a estrutura lógica desse conteúdo para que se possa dizer que a sentença foi justificada racionalmente.

Para definir o papel que a escolha valorativa entre diversas possibilidades desempenha na motivação, é necessário encará-la como signo natural e para definir a estrutura lógica da motivação, é necessário encará-la como signo institucional — isto é, com referência à sua função no discurso sentença. ${ }^{15}$ Uma maneira de encarar a motivação — ou um dos juízos que a compõem - como signo natural é partir do pressuposto de que não há coincidência entre as razões que levaram o juiz a tomar a decisão e as razões expressas na motivação. Partindo desse pressuposto, é possível interpretar a motivação como signo natural em busca dos verdadeiros motivos que levaram à tomada de decisão. ${ }^{16}$

\footnotetext{
${ }^{15}$ Idem, pp. 59-61.

${ }^{16}$ Idem, p. 75.
} 


\subsubsection{Motivação como signo natural capaz de fornecer indício das "razões reais" da decisão}

A busca pelas "razões reais" da decisão leva a dois caminhos. O primeiro deles busca identificar as escolhas práticas ou ético-políticas que o juiz fez, mas que não necessariamente foram expressas na motivação. Outro caminho é a identificação dos fatores de caráter psicológico, social e cultural que condicionam essas escolhas ${ }^{17} \mathrm{e}$, portanto, determinam a decisão. Esses dois caminhos não se excluem mutuamente e podem mesmo ajudar na significação um do outro, até porque a identificação das escolhas práticas ou ético-políticas que o juiz faz não pressupõe que essas escolhas sejam conscientes ou racionais, mas que possam sê-lo.

As escolhas (racionais) práticas e os condicionantes (irracionais) do juiz muitas vezes se confundem e se transformam uns nos outros. Por vezes, fatores psicológicos, sociais e culturais deixam de agir como condicionantes da decisão porque o juiz toma consciência desses fatores e os racionaliza. Após a racionalização, esses fatores passam atuar como valores capazes de ser critérios em juízos de valor.

Escolhas práticas, ético-políticas ou mesmo jurídicas tomadas pelo juiz podem, depois de muitas repetições, perder seu caráter consciente. Essas escolhas, assim, passam a ser tomadas de maneira automática. ${ }^{18}$ Esse processo, de transformações de decisões deliberadas em decisões intuitivas é descrito por GLADWELL ${ }^{19}$ e decorre da repetição exaustiva do mesmo processo de tomada de decisão. Esse fenômeno acontece, por exemplo, com enxadristas profissionais. ${ }^{20}$

\footnotetext{
${ }^{17}$ V., nesse sentido: DAMASIO, Antonio Rosa, Descartes' Error: Emotion, Reason, and the Human Brain, New York, Putnam, 1994, trad. port. de Vicente, Dora; Segurado, Georgina, O erro de Descartes: emoção, razão e o cérebro humano, São Paulo, Companhia das Letras 2006.

${ }^{18}$ TARUFFO, Michele, La motivazione della sentenza civile, cit. $n$. 1, pp. 76-79.

${ }^{19}$ Blink, New York, Back Bay Books, 2005, passim.

${ }^{20} \mathrm{http}: / / \mathrm{scienceblogs.com/cortex/2010/01/18/chess-intuition/,} \mathrm{acessado} \mathrm{em} \mathrm{8.1.2014.}$
} 


\subsubsection{Discurso demonstrativo $\mathrm{X}$ discurso justificativo}

A principal razão pela qual se pode dizer que a motivação é um discurso justificativo e não demonstrativo $^{21}$ é o fato de não ter só componentes lógicos, mas também retóricoargumentativos. Esses componentes são instrumentais à função justificativa que a motivação exerce no contexto do discurso sentença. ${ }^{22}$ Nesse sentido, a motivação é um discurso justificativo e argumentativo ${ }^{23}$, que deve convencer determinado auditório, que varia de acordo com cada ordenamento jurídico geográfica e cronologicamente localizado. $^{24}$

Os componentes lógicos e retórico-argumentativos da motivação se misturam e se confundem de tal modo que é impossível distingui-los topograficamente no âmbito da motivação. Por conta disso, a interpretação dos signos torna-se mais difícil, uma vez que pode ser difícil saber se um signo deve ser interpretado de acordo com seu contexto lógico ou fora dele. É possível, ainda, que uma proposição tenha, ao mesmo tempo, valor lógico e retórico $^{25}$ e que uma proposição retórica seja capaz de influir na interpretação de uma proposição lógica.

A presença de componentes retórico-argumentativos amplia o número de critérios de interpretação do significado da motivação, já que o significado de cada proposição depende do contexto no qual a proposição se insere. Assim, uma proposição que se insira apenas nesse contexto - ou não só nesse contexto - deverá ser interpretada - e adquirirá significado distinto — de maneira diferente de uma proposição que se insira exclusivamente no contexto lógico da motivação.

Alguns fenômenos típicos do discurso argumentativo influenciam a significação das proposições inseridas no contexto retórico-argumentativo da motivação. Dentre eles

\footnotetext{
${ }^{21}$ Gomes FILHO, Antonio Magalhães, A garantia da motivação das decisões judiciais na Constituição de 1988 in Processo penal e democracia: estudos em homenagem aos 20 anos da Constituição da República de 1988, Rio de Janeiro, Lumen Juris, 2009, p. 65; BADARó, Gustavo Henrique Righi Ivahy, Vícios de motivação da sentença penal: ausência de motivação, motivação contraditória, motivação implícita e motivação per relationem in Revista Brasileira de Ciências Criminais, v. 9, n. 38, 2002, p. 124.

${ }^{22}$ TARUFFO, Michele, La motivazione della sentenza civile, cit. $n .1$, p. 114.

${ }^{23}$ TuCCI, José Rogério Cruz e, A motivação da sentença no processo civil, cit. n. 3, pp. 21-22.

${ }^{24}$ GoMEs FILHO, Antonio Magalhães, A motivação das decisões penais, São Paulo, RT, 2001, pp. 13, 116117; A garantia da motivação das decisões judiciais na Constituição de 1988, cit. n. 21, p. 68.

${ }^{25} \mathrm{Na}$ hipótese de uma proposição se inserir tanto no contexto quanto no contexto retórico-argumentativo, seu significado é determinado por ambos os contextos.
} 
destacam-se a repetição, acumulação, redundância e aumento recíproco de significados entre essas proposições. O significado das proposições depende também de sua função no contexto retórico-argumentativo (e.g. se é premissa ou conclusão).

Uma das principais diferenças entre a intepretação de uma proposição no contexto retóricoargumentativo e no contexto lógico é no primeiro a ambiguidade e variabilidade de significado de uma proposição são mais evidentes e intencionais. Isso porque a ambiguidade e a variabilidade de significado são instrumentais à persuasão, já que evitam que as proposições sejam vistas como categóricas ou radicais. ${ }^{26}$

\subsubsection{Significado da motivação}

A definição do significado da motivação depende antes de uma definição do que não é seu significado. Nesse ponto, é importante esclarecer porque o significado da motivação não são as "razões reais" da sentença.

Em primeiro lugar, porque a motivação não exprime somente as razões que levaram à sentença. A estrutura do raciocínio que leva a sentença é heurística, hipotética e avaliativa, diferente da estrutura do raciocínio que justifica racionalmente a sentença. O raciocínio da decisão passa pela intuição, pela assunção de hipóteses de trabalho e por escolhas valorativas realizadas imediatamente. No raciocínio de justificação, a intuição deve ser argumentada, as hipóteses de trabalho devem ser confirmadas e as escolhas valorativas devem ser convalidadas racionalmente. O conteúdo do raciocínio de justificação, portanto, é analisado com maior profundidade que o conteúdo do raciocínio decisório. Outra diferença entre essas duas espécies de raciocínio diz respeito à presença mais frequente de deduções no raciocínio justificativo - embora o recurso exclusivo ao esquema dedutivo seja falha por ser incapaz de demonstrar as premissas na base da dedução. Também estão presentes somente no raciocínio justificativo a argumentação retórica, os obiter dicta e o cúmulo de rationes decidendi no mesmo sentido.

Em segundo lugar, a motivação não representa a totalidade do raciocínio decisório. Mesmo que o juiz quisesse descrever todo o processo psicológico que o levou à tomada de decisão,

${ }^{26}$ TARUFFO, Michele, La motivazione della sentenza civile, cit. $n .1$, pp. $115-117$ e n. 9. 
essa descrição seria impossível por conta do caráter inconsciente de algumas escolhas que levaram à decisão, bem como de condicionamentos ignorados ou desconhecidos pelo juiz. Mesmo que a motivação refletisse fielmente o raciocínio decisório do juiz, essa estaria incompleta, pois não cumpriria sua função no discurso sentença, que é de justificar a decisão e não somente explicá-la. Mesmo as etapas mais lógicas do raciocínio decisório formulação e adaptação das hipóteses de fato e de direito; formulação e controle das hipóteses de trabalho utilizadas no plano da cognição — não são refletidas na motivação. Isso porque não só essas etapas são muitas vezes contraditórias como também não interessam à justificação racional da decisão, que se interessa só pelas razões finais da decisão. O mesmo ocorre quanto aos juízos valorativos. Não é necessário que da motivação conste todo o complexo processo de valoração do juiz, mas é necessário que dela conste uma justificação válida para o resultado dessa valoração (infra, 3.5.4).

A distinção entre iter decisório e motivação decorre de alguns conceitos básicos de semiologia. Um signo (e.g. a palavra "gato") denota um referente externo (e.g. um gato que existe fisicamente) e designa um significado (e.g. felino doméstico de pequeno porte). Desse conceito é possível perquirir se a motivação (signo) designa ou denota o raciocínio do juiz.

A motivação não designa o raciocínio do juiz porque o que determina seu significado são sua estrutura e função. Assim, se a motivação tem função justificativa, não pode designar o raciocínio do juiz, que tem caráter heurístico, valorativo e deliberativo. A motivação designa - ou seja, significa — um conjunto orgânico de significados das proposições que a compõem mediante o qual o juiz justifica — ou seja, torna-a racionalmente válida, legítima e aceitável - argumentativamente sua decisão. A motivação também não denota o raciocínio decisório porque não o explica, justifica-o. O que a motivação denota - ou seja, se refere a - é o conjunto de razões que o juiz considerou aptas a justificar sua decisão. $^{27}$

${ }^{27}$ Idem, pp. 119-123, 125-126. 


\subsubsection{Motivação como discurso racional}

Feita a distinção entre motivação e decisão, e caracterizada a motivação como justificação da decisão, é necessário acrescentar que se trata da justificação racional da decisão. Para entender essa afirmação, é necessário entender a relação entre Lógica e Direito (item 2.1.2.1). Com base nos esclarecimentos desse item, será possível enfrentar as críticas que se fazem ao caráter lógico e racional da decisão judicial e da motivação (item 2.1.2.2) e demonstrar qual a função da lógica na motivação (item 2.1.2.3). Por fim, será enfrentado um dos pontos sensíveis na relação entre Lógica e Direito, nomeadamente a possibilidade de uso da lógica nos momentos valorativos ínsitos à decisão judicial (item 2.1.2.4).

\subsubsection{Lógica e Direito}

Para discorrer sobre o possível caráter racional da motivação ou do raciocínio decisório é necessário, antes, precisar qual o papel da lógica no raciocínio jurídico. A Lógica é a ciência do raciocínio e, como designa um objeto bem definido, é necessário ter atenção quando se utiliza expressões como "lógica argumentativa" ou "lógica do juízo".

A expressão "lógica do direito" tem como significado "racionalidade do conjunto de normas que compõem o ordenamento", o que não interessa diretamente às questões relativas à motivação, mas, de qualquer maneira, influenciaram o conceito de "juízo". Nesse contexto, a decisão é encarada como operação puramente dedutiva e cognitiva, em harmonia com a estrutura lógica do ordenamento.

A expressão "Lógica" também é utilizada no contexto do Direito para designar o estudo de normas com métodos da Lógica (ciência) ou o conjunto de instrumentos conceituais que o intérprete utiliza para determinar o significado de um texto normativo. Quando se fala na lógica do juiz, por vezes se refere a uma manifestação particular da Lógica no raciocínio jurídico, em outras à racionalidade considerada indispensável ao exercício da jurisdição, por vezes ao silogismo judicial e, por fim, à lógica dedutiva aplicada à norma. ${ }^{28}$

${ }^{28}$ Idem, pp. $126-130$ e n. 33. 


\subsubsection{Críticas ao caráter lógico e racional da decisão judicial e da motivação e resposta às críticas}

Segundo a concepção positivista clássica, o emprego de categorias lógicas é a característica prevalente do raciocínio judicial. Nos sistemas de common law, essa concepção resultou no modelo segundo o qual, por meio de um raciocínio indutivo, extraía-se a norma geral do caso particular e, por meio de um raciocínio dedutivo, aplicava-se essa norma a um caso particular. Nos sistemas de civil law, a decisão era visto como uma dedução (necessária) das normas gerais e abstratas. ${ }^{29}$

Várias correntes e teorias criticaram o positivismo e suas premissas e, embora todas tenham abordagens e consequências diferentes, é constante a recusa à configuração lógica da atividade do juiz e a visão de que essa atividade tem natureza criativa. Dentre essas correntes, destaca-se o realismo norte-americano, ${ }^{30}$ que criticou tanto a subsunção (rule skepticism) quanto a natureza racional da determinação dos fatos (fact skepticism). Esses ataques tinham como fundamento uma concepção da decisão judicial como processo irracional e levaram à radicalização da distinção entre "motivos reais" e motivação expressa. Nessa perspectiva, a motivação é encarada como algo inútil para revelar os motivos da decisão judicial e alguns autores chegam a afirmar que, mesmo que a decisão judicial seja irracional, a motivação deve refletir fielmente esse processo de tomada de decisão. $^{31,32}$

Esses ataques ao caráter lógico do juízo, no entanto, decorrem de equívocos na compreensão dos problemas enfrentados. O conservadorismo da jurisprudência norteamericana e inglesa, alvo de ataques dos realistas, tinha raízes sociopolíticas e não na lógica. Outros ataques à lógica na realidade não se direcionavam ao uso de instrumentos lógicos, mas ao mal uso da lógica pelos juízes. Por fim, a antítese que os realistas enxergavam entre lógica e experiência é falsa, pois deriva de uma visão reducionista da lógica, que só abrangeria a lógica dedutiva.

\footnotetext{
${ }^{29}$ Idem, 1975, pp. 132-133.

${ }^{30}$ Ver, e.g., RUMBLE, Wilfrid, American Legal Realism; Skepticism, Reform, and the Judicial Process, New York, Cornell University Press, 1968; PosneR, Richard A., How judges think, Cambridge, Harvard University Press, 2008.

${ }^{31}$ Uma motivação dessa natureza seria impossível, até por conta do caráter irracional e intuitivo da decisão que os realistas pressupõem

32 TARUFFO, Michele, La motivazione della sentenza civile, cit. n. 1, pp. 94-100.
} 
No direito continental, as correntes antipositivistas e antiformalistas focavam seus ataques na interpretação e aplicação da norma. Esses ataques, no entanto eram focados menos na atividade do juiz e mais nas técnicas e cânones interpretativos e na relação entre normas e interesses sociais.

Antes de analisar a possibilidade de racionalidade e logicidade no raciocínio decisório e na motivação, é necessário rejeitar dois sofismas. O primeiro desses sofismas postula que a atividade do juiz compreende tão-somente raciocínios dedutivos. Esse sofisma ignora a complexidade da Lógica, reduzindo-a ao raciocínio indutivo, e também os limites do raciocínio dedutivo, de pouca utilidade nos momentos valorativos e criativos do raciocínio decisório.

O segundo sofisma postula que toda concepção racional do raciocínio decisório e da motivação equivale ao primeiro sofisma e, existindo momentos do raciocínio decisório que não se estruturam sob a forma da dedução, não existe espaço para a Lógica no raciocínio do juiz. Esse sofisma é criticável não só porque procura negar a validade a toda a Lógica no raciocínio judicial ao expor a insuficiência de um de seus instrumentos (a dedução), mas também porque ignora que dizer que o raciocínio do juiz é indutivo significa a incapacidade de analisá-lo, o que impede a possibilidade de construir um modelo do raciocínio decisório. ${ }^{33}$

Mesmo que se entenda que o raciocínio decisório é irracional, ainda assim seria possível caracterizar a motivação como justificativa racional da decisão. A motivação funciona como um (auto-)controle ex post da decisão judicial e mesmo sendo a motivação (necessariamente) racional e a decisão (potencialmente) irracional, esse controle pode, ainda assim, ser efetivo.

Na maioria dos casos, quando o juiz motiva sua decisão, fá-lo após tomar, mesmo que intuitivamente, sua decisão e vai sempre tentar encontrar motivos para justificar a decisão que já tomou. Ocorre que, se encarada como justificação racional (e completa) da decisão, a exigência de motivação pode fazer com que o juiz seja forçado a abandonar a decisão que

${ }^{33}$ Idem, pp. 134-136, 138-139. 
havia tomado intuitivamente, por ser impossível de justificá-la racionalmente. É dessa maneira que a motivação é capaz de influir e até mesmo condicionar o processo decisório, ${ }^{34}$ mesmo que se considere que esse processo é irracional. Essa possibilidade, ${ }^{35}$ por si só fundamenta a função da motivação como justificação racional da decisão.

Um paralelo interessante entre a necessidade de justificação racional de uma decisão (potencialmente) irracional é a justificativa de DwORKIN para a responsabilidade sobre as ações humanas. ${ }^{36}$ No campo da Ética e da Moral, a responsabilidade existe na ação humana mesmo que a decisão não seja racional, pelo simples fato de que é uma decisão. Isso porque, o fato de ser uma decisão implica que havia a possibilidade de outro modo de ação e, mesmo considerando que não existe, de fato, livre arbítrio, ${ }^{37}$ o ser humano tem a faculdade de pensar nas possibilidades de ação que pode tomar. Da mesma forma, mesmo que o juiz tome sua decisão intuitivamente ou irracionalmente, ${ }^{38}$ existe a possibilidade de tomar a decisão de forma racional. Essa possibilidade de tomada racional da decisão implica a possibilidade de justificação racional da decisão.

\subsubsection{Uso da lógica no raciocínio decisório e no raciocínio justificativo}

Ao encarar a Lógica como algo além da lógica formal dedutiva, abre-se a possibilidade de diversos instrumentos lógicos distintos, seja no raciocínio decisório, seja em sua justificação. O caráter instrumental desses recursos que a Lógica põe ao dispor do juiz significa que são desvinculados dos conteúdos do raciocínio. Assim, o juiz pode escolher livremente o instrumento lógico mais adequado para cada etapa de seu raciocínio, sem acrescentar nenhum conteúdo ao objeto ao qual é aplicada, mas fazendo desse objeto surgir uma estrutura racional.

Existem, no entanto, alguns limites à utilização da Lógica pelo juiz. O primeiro desses limites diz respeito à seleção do instrumento lógico mais adequado ao material conceitual

\footnotetext{
${ }^{34}$ Gomes FILHO, Antonio Magalhães, A motivação das decisões penais, cit. n. 24, pp. 113-115.

${ }^{35}$ Confirmada por estudos empíricos, GuTHRIE, Chris; RACHLINSKI, Jeffrey J.; WistRICH, Andrew J., Blinking on the Bench: How Judges Decide Cases in Cornell Law Review, v. 93, n. 1, 2007, pp. 36-37.

${ }^{36}$ Justice for hedgehogs, Cambridge, Harvard University, 2011, pp. 219-225.

${ }^{37} \mathrm{O}$ que ocorreria por que todas as nossas decisões seriam condicionadas por fatores externos. V. WATSON, Gary (org.), Free Will, Oxford, Oxford University Press, 2003; KANE, Robert, The Oxford Handbook on Free Will, Oxford, Oxford University Press, 2005.

${ }^{38}$ Esses dois modos de tomada de decisão podem ser sinônimos mas não necessariamente o são. V. GLADWELL, Malcolm, Blink, cit. n. 19.
} 
no qual se aplica. Desse modo, é inadequado recorrer a um raciocínio dedutivo se não houver uma premissa maior aplicável.

O segundo desses limites é a necessidade de respeitar a estrutura e as possibilidades do instrumento lógico escolhido. Assim, de um raciocínio indutivo-dedutivo (semelhante ao que se utiliza na interpretação dos indícios como fonte de prova — ver infra 4.3.2.3) não se chegará a uma consequência lógica necessária, mas a um resultado probabilístico.

O terceiro desses limites é o fato de que o recurso a um instrumento lógico não altera o conteúdo do objeto sobre o qual é aplicado. Assim, por exemplo, a utilização do raciocínio dedutivo não é capaz de transformar em certa ou verdadeira uma premissa que não o é nem é possível, por meio da Lógica, extrair conclusões axiológicas de premissas de fato. ${ }^{39,40}$

A possibilidade de utilização de todos esses instrumentos da Lógica não significa que nela se esgote o raciocínio do juiz, mas esses instrumentos são essenciais tanto para o raciocínio decisório quanto para sua justificação e controle racional de suas premissas e procedimento. $^{41}$

O juiz pode utilizar instrumentos da Lógica tanto no raciocínio decisório quanto no justificativo, mas isso não significa que os raciocínios sejam iguais nem que haja uma correspondência entre eles quanto aos momentos nos quais é possível o recurso à Lógica. Essa conclusão não se altera pelo fato de existirem entre os dois raciocínios nexos de fato. Nesse sentido, o dever de motivar a decisão induz o juiz a racionalizar o processo decisório $^{42}$ ao passo que o raciocínio decisório influencia o modo como ele é justificado. ${ }^{43}$

A necessidade de motivação das decisões judiciais condiciona o conteúdo dessas decisões ao exigir que o discurso judicial na fundamentação seja racional e coerente. Assim, o

\footnotetext{
${ }^{39}$ TARUFFO, Michele, La motivazione della sentenza civile, cit. $n$. 1, pp. 140-143.

${ }^{40}$ A impossibilidade de extrair conclusões axiológicas diretamente de premissas de fato é de enorme importância na ética e moral e corresponde ao princípio de Hume que fundamenta, por exemplo, grande parte das conclusões de DWORKIN em Justice for Hedgehogs. Segundo esse postulado, as ciências valorativas (ética, moral, direito) estruturam-se de maneira autônoma e sobre seus próprios fundamentos, que são valorativos e não de fato.

${ }^{41}$ TARUFFO, Michele, La motivazione della sentenza civile, cit. $n$. 1, p. 143.

${ }^{42}$ Guthrie, Chris; RACHLInski, Jeffrey J.; Wistrich, Andrew J., Blinking on the Bench: How Judges Decide Cases, cit. n. 35, pp. 36-37.

${ }^{43}$ TARUFFO, Michele, La motivazione della sentenza civile, cit. $n .1$, pp. 144-145.
} 
raciocínio decisório levará em conta somente razões confessáveis. ${ }^{44}$ A motivação da decisão judicial seria uma racionalização ex post de uma decisão que não é necessariamente racional ${ }^{45}$. No entanto, ao impor a necessidade de fundamentação das decisões judiciais, a intenção do legislador é exatamente a de assegurar que o raciocínio decisório seja racional. Isso porque, tendo o julgador que expor os motivos de sua decisão, o campo para a tomada de decisões arbitrárias e injustificáveis objetivamente diminui muito. 46

\subsubsection{Racionalidade e valoração}

Um dos problemas que se coloca ao discutir sobre a racionalidade, seja do raciocínio decisório, seja do raciocínio justificativo, surge ao se cogitar da racionalidade no momento valorativo desses discursos. É importante ter a consciência do papel decisivo que a atividade valorativa desempenha no raciocínio decisório, embora os modos, características e consequências dessa atividade não tenham sido completamente esclarecidos. Essa atividade valorativa, no entanto, não compõe a totalidade do raciocínio decisório, que apresenta momentos lógico-racionais.

O problema da valoração no raciocínio decisório e no raciocínio justificativo diz respeito a como e com qual fim o juiz realiza essas valorações axiológicas, de modo a permitir o controle externo - jurídico e político-social - dessa valoração. Quanto ao raciocínio decisório, é importante analisar a valoração sob o ponto de vista da escolha do valor como critério para a valoração, da formulação do juízo de valor e da inserção do juízo de valor no raciocínio decisório.

Quanto ao raciocínio justificativo, é importante analisar a justificação da escolha do valor como critério para a valoração, a justificação do juízo de valor e a justificação das consequências que o juiz extrai do juízo de valor para a decisão. ${ }^{47}$ A escolha do valor pode ser justificada de acordo com a sua posição em determinado sistema de valores, mas ainda

\footnotetext{
${ }^{44}$ Gomes FILHO, Antonio Magalhães, A garantia da motivação das decisões judiciais na Constituição de 1988, cit. n. 21 , pp. 60; 69.

${ }^{45}$ GOMES FilHo, Antonio Magalhães, A motivação das decisões penais, cit. n. 24, pp. 111-112.

${ }^{46}$ Gomes FILHO, Antonio Magalhães, A garantia da motivação das decisões judiciais na Constituição de 1988, cit. n. 21 , pp. 66-67.

${ }^{47}$ TARUFFO, Michele, La motivazione della sentenza civile, cit. n. 1, pp. 145-147.
} 
assim, a escolha do sistema de valores será retórico-argumentativa ${ }^{48}$. A justificação do juízo de valor, por sua vez, deve ser feita de acordo com critérios lógicos — isto é, deve ser demonstrado que a utilização de determinado valor como critério leva logicamente a determinada consequência.

\subsection{Funções endoprocessuais da motivação}

Uma vez estabelecido que a motivação é a justificação racional da decisão judicial, é necessário analisar qual a função da motivação dentro do ordenamento. Nesse sentido, nem todas as manifestações do dever de fundamentação das decisões têm o mesmo significado jurídico e político. A principal diferença entre o significado que assume o dever de fundamentar as decisões diz respeito ao fato de ser encarada como instrumento técnicoprocessual - decorrente da legislação infraconstitucional - ou como garantia políticoconstitucional. $^{49}$

A função da motivação, segundo a legislação infraconstitucional, é endoprocessual — isto é, de racionalização do sistema processual. Nessa perspectiva, ela tem a função de convencer as partes da "justiça" da decisão, desencorajando a impugnação da mesma. ${ }^{50} \mathrm{~A}$ função de desencorajar a impugnação, no entanto, resulta em uma configuração muito restrita do dever de motivação, que só se aplicaria às decisões impugnáveis.

Também sob a ótica endoprocessual, entende-se que a motivação tem o objetivo de permitir que as partes impugnem a decisão, ${ }^{51}$ facilitando a identificação de seus vícios e permitindo que se atenda ao requisito da impugnação específica dos recursos. ${ }^{52}$ Além de

\footnotetext{
${ }^{48}$ Gomes FILHO, Antonio Magalhães, A motivação das decisões penais, cit. $n$. 24, pp. 182-185.

49 TARUFFO, Michele, La motivazione della sentenza civile, cit. $n .1$, pp. 370-374.

${ }^{50}$ GOMES FILHO, Antonio Magalhães, A motivação das decisões penais, cit. n. 24, p. 96.

${ }^{51}$ Garcia, André Almeida, Prova Civil, São Paulo, Saraiva, 2009, p. 81; CADIET, Loïc; MeKKI, Soraya Amrani; e NoRMAND, Jacques, Théorie générale du procès, Paris, PUF, 2010, p. 680-681; GUINCHARD, Serge et al, Droit processuel: droits fondamentaux du procès, $6^{\mathrm{a}}$ ed. Paris, Dalloz, 2011, p. 1007; SoUZA, Wilson Alves de, Sentença civil imotivada: caracterização da sentença civil imotivada no direito brasileiro, Salvador, Juspodivm, 2008, p. 194; CinTrA, Antônio Carlos de Araújo; Grinover, Ada Pelegrini; DinAmarco, Cândido Rangel, Teoria Geral do Processo, $23^{\mathrm{a}}$ ed., São Paulo, Malheiros, 2007, p. 74; BUENO, Cássio Scarpinella, Curso sistematizado de direito processual civil, v. 1, São Paulo, Saraiva, 2007, p. 132; FRANCO, Fernão Borba, Aproximação entre processo judicial e administrativo: um enfoque sobre o procedimento e a motivação, Tese (Doutorado) - Faculdade de Direito de USP, São Paulo, 2006, p. 182; BADARÓ, Gustavo Henrique Righi Ivahy, Vícios de motivação da sentença penal: ausência de motivação, motivação contraditória, motivação implícita e motivação per relationem, cit. n. 21, p. 124; GOMES FILHO, Antonio Magalhães, A motivação das decisões penais, cit. n. 24, p. 103.

${ }^{52}$ Ex arts. 514 II; 515 caput; 524, I e II; 530; 536; e 541, I e III, todos do CPC.
} 
permitir que as partes impugnem a decisão, o dever de motivação permite o controle das decisões pelo Juízo a quo na impugnação. Também essa função da motivação só permite entender que o dever de fundamentar só se estenda às decisões impugnáveis.

Ainda sob essa ótica, a motivação tem a função de definir precisamente o conteúdo da decisão, de modo a permitir, por exemplo, a determinação dos limites objetivos da coisa julgada. $^{53}$

A função endoprocessual da motivação de permitir o controle das decisões pelo Juízo $a$ quo na impugnação sequer justifica a necessidade de publicidade da decisão motivada. Isso porque é possível imaginar um sistema no qual as partes sequer tenham conhecimento dos motivos da decisão e, mesmo assim a decisão sobre as impugnações seria possível. Nessa situação hipotética, os motivos da decisão precisariam ser revelados somente ao juízo competente para julgar a impugnação. ${ }^{54}$

O dever de motivação das decisões judiciais pode ser encarado como um modo de permitir que os tribunais de superposição cumpram sua função nomofilática e de unificação da jurisprudência. ${ }^{55}$ A função nomofilática e de unificação de jurisprudência dos tribunais de superposição só pode ser exercida se a sentença sobre a qual se operará o controle de legalidade ou constitucionalidade houver fundamentado o raciocínio de interpretação da norma.

Nesse ponto vale notar que o controle de legalidade sobre uma decisão não significa um juízo sobre a decisão, mas sobre a premissa normativa que o juiz afirme ter utilizado na decisão. A função de unificação de jurisprudência exercida pelos tribunais de superposição, especificamente, é capaz de justificar que o dever de fundamentação das decisões judiciais estenda-se também às decisões não impugnáveis. Assim, as decisões dos tribunais de superposição só poderão cumprir sua função de unificação da jurisprudência,

\footnotetext{
${ }^{53}$ TARUFFO, Michele, La motivazione della sentenza civile, cit. n. 1, pp. 374-382; GOMES FILHO, Antonio Magalhães, A motivação das decisões penais, cit. n. 24, p. 95; A motivação das decisões judiciais na Constituição de 1988: funções políticas e processuais in Revista do Advogado v. 28, n. 99, 2008, p. 17; A garantia da motivação das decisões judiciais na Constituição de 1988, cit. n. 21 , p. 62; TUCCI, José Rogério Cruz e, A motivação da sentença no processo civil, cit. n. 3, p. 134.

54 TARUFFO, Michele, La motivazione della sentenza civile, cit. $n$. 1, pp. 380-384.

55 RECENA COSTA, Guilherme, Superior Tribunal de Justiça e recurso especial: análise da função e reconstrução dogmática, Dissertação (Mestrado) - Faculdade de Direito de USP, São Paulo, 2011, pp. 98135; GoMES FILHO, Antonio Magalhães, A motivação das decisões penais, cit. n. 24, p. 88.
} 
se forem motivadas, isto é, se justificarem a solução interpretativa que entendem ser a mais correta. Ainda assim, mesmo com a extensão do dever de fundamentação às decisões não impugnáveis, o perfil que se traça desse dever com fundamento nas normas infraconstitucionais ainda é reduzido e incompleto. ${ }^{56}$

\subsection{Funções extraprocessuais da motivação}

Além das funções que a motivação exerce dentro do processo, cuja análise se desenvolveu no item 2.2, ela exerce funções extraprocessuais, decorrentes da previsão constitucional do dever de fundamentar as decisões judiciais. Essas funções extraprocessuais da motivação, assim como sua função linguístico-pragmática e suas funções endoprocessuais, determinam sua estrutura e conteúdo. A influência das funções extraprocessuais na determinação da estrutura e conteúdo da motivação decorre da aplicação das normas constituconais na construção do processo civil, segundo o modelo constitucional do direito processual civil ${ }^{57}$.

A primeira maneira de encarar a norma constitucional que impõe ao juiz o dever de fundamentação das suas decisões é como uma "norma sobre normas", que altera os efeitos das normas infraconstitucionais. Sob esse prisma, norma constitucional impede a edição de normas tendentes a limitar ou eliminar o dever de fundamentação das decisões judiciais e realiza uma função de integração interpretativa de modo que se entenda que todo ato com conteúdo decisório emanado do Poder Judiciário deve ser motivado. ${ }^{58}$

A previsão constitucional do dever de fundamentação das decisões judiciais também pode ser vista sob a ótica do caráter instrumental da motivação em relação a outras normas processuais de matriz constitucional — objeto de análise do item 2.3.1. As funções extraprocessuais da motivação não se esgotam, no entanto, em seu caráter instrumental e, nessa perspectiva, decorrem também do significado do dever constitucional, imposto ao juiz, de fundamentar suas decisões. Para determinar esse significado, é necessário entender a relação entre motivação e Estado Democrático de Direito (item 2.3.2) e a forma como se estrutura a norma que veicula esse dever (item 2.3.3)

\footnotetext{
56 TARUFFO, Michele, La motivazione della sentenza civile, cit. $n$. 1, pp. 384-392.

${ }^{57}$ BuEno, Cássio Scarpinella, O modelo constitucional do direito processual civil: um paradigma necessário ao estudo do direito processual civil e suas aplicações in Revista de Processo, v. 33, n. 161, 2008, p. 262.

${ }^{58}$ TARUFFO, Michele, La motivazione della sentenza civile, cit. $n .1$, pp. 393-398.
} 


\subsubsection{Motivação e normas processuais constitucionais}

O dever de fundamentação das decisões judiciais pode ser encarado como uma das garantias que a Constituição confere ao indivíduo em face do Estado. Visto dessa maneira, o dever de fundamentação tem uma função instrumental em relação às demais garantias que o cidadão tem em face do Poder Judiciário.

Dentre essas garantias do cidadão, destaca-se a de imparcialidade do juiz, que decorre da garantia de independência do próprio juiz. ${ }^{59}$ Ora, a imparcialidade do juiz só pode ser aferida concretamente quando analisada a motivação da decisão, de modo que a decisão só poderá ser considerada tomada por juiz imparcial se este demonstrar sê-lo. ${ }^{60}$

A relação entre motivação e imparcialidade é mais clara quando se encara a motivação como signo natural. Não se interpreta a motivação como signo institucional, já que não há intenção de descobrir o que o juiz tentou comunicar. Interpreta-se a motivação como indicativo de que o juiz favoreceu uma das partes, ou seja, como signo natural. ${ }^{61}$

A motivação também assume caráter instrumental em relação à garantia de sujeição do juiz à lei ${ }^{62,63}$ - que também pode ser vista como garantia de legalidade da decisão judicial.

\footnotetext{
${ }^{59}$ Ex art. 95, CF.

${ }^{60}$ CADIET, Loïc; MeKKI, Soraya Amrani; e Normand, Jacques, Théorie générale du procès, cit. $n$. 51 , p. 684; SouZA, Wilson Alves de, Sentença civil imotivada: caracterização da sentença civil imotivada no direito brasileiro, cit. n. 51, pp. 193-194; CARMONA, Carlos Alberto, Arbitragem e Processo: um comentário à Lei $n^{o}$ 9.307/96, $3^{\mathrm{a}}$ ed., São Paulo, Atlas, 2009, p. 476; OliveIRA, Pedro Miranda de, Princípios constitucionais do processo civil no âmbito recursal in Processo e Constituição: estudos em homenagem ao professor José Carlos Barbosa Moreira, coord. FuX, Luiz; NERY JUNIOR, Nelson; e WAMBIER, Teresa Arruda Alvim, São Paulo, RT, 2006, p. 565; GoMES FILHO, Antonio Magalhães, A motivação das decisões judiciais na Constituição de 1988: funções políticas e processuais, cit. n. 53, p. 18; A garantia da motivação das decisões judiciais na Constituição de 1988, cit. n. 21, pp. 63-64; TuCCI, José Rogério Cruz e, A motivação da sentença no processo civil, cit. n. 3, p. 23; Garantias constitucionais da publicidade dos atos processuais e da motivação das decisões no Projeto de CPC in Revista do Advogado, v. 32, n. 117, 2012, p. 116; BADARÓ, Gustavo Henrique Righi Ivahy, Vícios de motivação da sentença penal: ausência de motivação, motivação contraditória, motivação implícita e motivação per relationem, cit. n. 21, p. 126.

${ }^{61}$ Gomes FILHO, Antonio Magalhães, A motivação das decisões penais, cit. n. 24, pp. 99; A garantia da motivação das decisões judiciais na Constituição de 1988, cit. n. 21 , p. 63.

${ }^{62}$ Que decorre do artigo $5^{\circ}$, II, CF.

${ }^{63}$ A sujeição do juiz à lei ganha contornos mais dramáticos na esfera penal, em virtude do postulado "nulla poena sine lege", conforme GOMES FILHO, Antonio Magalhães, A motivação das decisões penais, cit. n. 24 , pp. 85-86.
} 
Isso por que só é possível aferir a legalidade da decisão quando sua motivação for capaz de demonstrar a legalidade. ${ }^{64}$

GOMES FILHO sustenta que a motivação da decisão possibilita a efetivação do duplo grau de jurisdição, pois a impugnação da decisão pela parte, bem como sua análise e eventual reforma pelo órgão superior só serão possíveis se conhecidas todas as razões que efetivamente levaram à decisão. ${ }^{65}$ Quanto a esse ponto, um esclarecimento é necessário. De fato, a motivação é instrumental ao duplo grau de jurisdição e possibilita sua efetivação. No entanto, a possibilidade de reanálise das decisões por um órgão hierarquicamente superior não depende necesariamente da fundamentação dessas decisões.

Isso porque, em primeiro lugar, é possível imaginar um sistema de "justiça de cádi”"66 no qual tanto o juiz hierarquicamente inferior quanto o órgão revisor profiram suas decisões com base na convicção íntima e sem qualquer fundamentação. Além disso, o Tribunal pode, mesmo no nosso atual sistema processual, dar provimento a um recurso sem ler a motivação da decisão recorrida. É o que ocorre quando a sentença é anulada por vícios formais.

Especificamente quanto à sentença penal, o fato de a Constituição trazer disposições semelhantes quanto à necessidade de fundamentação das decisões restritivas de liberdade em seus artigos $5^{\circ}$, LXI e 93, IX não deve ser interpretado como redundância. Nesses casos, há um reforço da necessidade de fundamentação das decisões judiciais em virtude de essas restringirem o direito fundamental à liberdade. ${ }^{67}$

\footnotetext{
${ }^{64}$ MotUlSKY, Henri, Écrits: études et notes de procédure civile, 1973, $2^{\mathrm{a}}$ ed. Paris, Dalloz, 2010, pp. 33, 42; GUINCHARD, Serge et al, Droit processuel: droits fondamentaux du procès, cit. n. 51, pp. 1006-1007; SouZA, Wilson Alves de, Sentença civil imotivada: caracterização da sentença civil imotivada no direito brasileiro, cit. n. 51, p. 195; MENEZES DIREITO, Carlos Alberto, A decisão judicial in Revista da EMERJ, v. 3, n. 11, Rio de Janeiro, 2000, p. 47; GOMES FILHO, Antonio Magalhães, A motivação das decisões penais, cit. $n$. 24, pp. 84-86; A motivação das decisões judiciais na Constituição de 1988: funções políticas e processuais, cit. n. 53, p. 16; A garantia da motivação das decisões judiciais na Constituição de 1988, cit. n. 21 , p. 61; TUCCI, José Rogério Cruz e, A motivação da sentença no processo civil, cit. n. 3, p. 100.

${ }^{65}$ Gomes Filho, Antonio Magalhães, A garantia da motivação das decisões judiciais na Constituição de 1988, cit. n. 21, p. 64.

${ }^{66}$ WeBER, Max, Wirtschaft und Gesellschaft: Grundiss der versteheden Soziologie, trad. port. de Barbosa, Regis e Barbosa, Karen Elsabe, Economia e sociedade: fundamentos da sociologia compreensiva, v. 2, UnB, Brasília, 1999, p. 518.

${ }^{67}$ GOMES FILHO, Antonio Magalhães, A garantia da motivação das decisões judiciais na Constituição de 1988, cit. n. 21, p. 59.
} 
Na realidade, o dever de fundamentação das decisões judiciais se afigura como garantia secundária dos direitos fundamentais, pois permite que se controle se a restrição a um direito fundamental seriaera permitida no caso concreto. ${ }^{68}$ Isso porque a restrição a direitos fundamentais impõe ao juiz um ônus argumentativo e somente a motivação permite a verificação do desincumbimento desse ônus.

Por fim, o dever de fundamentação das decisões judiciais é instrumental ao contraditório e à ampla defesa. Aqui, a motivação não só permite verificar que as partes puderam expor suas razões, como também, mais importante do que isso, verificar se o juiz levou em conta as razões das partes, mesmo que não adote essas razões. ${ }^{69}$.

Ao se falar em contraditório, é necessário entendê-lo não só como o direito a expor seus argumentos, mas entender o contraditório como influência. Assim, não basta garantir às partes o direito de expor seus argumentos; é necessário garantir que suas alegações serão capazes de influenciar o comportamento dos demais sujeitos processuais. ${ }^{70}$ No que se refere mais especificamente à motivação da decisão - a questão será mais bem explorada nos itens 2.3.2.3 e 5.1 —, o direito ao contraditório significa o direito a influenciar a tomada de decisão. ${ }^{71}$

Entendido o contraditório como direito a influir na formação da decisão judicial, deixa de fazer sentido afirmar que o juiz não tem que analisar e motivar o acolhimento ou rejeição de todas as alegações das partes. ${ }^{72}$ Nessa perspectiva, mesmo as alegações ou requerimentos de produção de prova que o juiz entenda serem absurdas deverão ser

\footnotetext{
${ }^{68}$ Gomes FILHO, Antonio Magalhães, A motivação das decisões penais, cit. n. 24, p. 48, 91-94; A motivação das decisões judiciais na Constituição de 1988: funções políticas e processuais, cit. n. 53, p. 17; A garantia da motivação das decisões judiciais na Constituição de 1988, cit. n. 21, pp. 61-62;

${ }^{69}$ TARUFFO, Michele, La motivazione della sentenza civile, cit. $n$. 1, pp. 398-403; GuINCHARD, Serge et al, Droit processuel: droits fondamentaux du procès, cit.n. 51, p. 1134; GRECO, Leonardo, Garantias fundamentais do processo: o processo justo in Novos Estudos Jurídicos, v. 7, n. 14, Itajaí, 2002, p. 32; SouZA, Wilson Alves de, Sentença civil imotivada: caracterização da sentença civil imotivada no direito brasileiro, cit.n. 51, p. 195; LACERDA, Maria Francisca dos Santos e ZAGANELLI, Margareth Vetis, Livre apreciação da prova, ciência e raciocínio judicial: considerações sobre a 'cientifização' da prova no processo in Processo, verdade e justiça: estudos sobre a prova judicial, Rio de Janeiro, Lumen Juris, 2009, p. 167.

${ }^{70}$ CABRAL, Antonio do Passo, Nulidades no processo moderno: contraditório, proteção da confiança e validade prima facie dos atos processuais, processuais, $2^{\mathrm{a}}$ ed., Rio de Janeiro, Forense, 2010, pp. 112-158; GOMES FILHO, Antonio Magalhães, A motivação das decisões penais, cit. n. 24, p. 100.

${ }^{71}$ Gomes FILHO, Antonio Magalhães, A garantia da motivação das decisões judiciais na Constituição de 1988, cit. n. 21 , pp. 63-64.

${ }^{72}$ TARUFFO, Michele, La motivazione della sentenza civile, cit. $n .1$, p. 404.
} 
rejeitadas fundamentadamente, mesmo que a fundamentação se limite a declarar que carecem de sentido a alegação ou os requerimentos de produção de prova. $^{73}$

O abuso do direito ao contraditório não pode ser sancionado com a diminuição do dever de fundamentação, até porque o juiz já dispõe de mecanismos aptos a sancionar esse abuso. Na esfera civil, pode impor a multa por litigância de má-fé prevista no artigo 17 do Código de Processo Civil. Na esfera penal, embora não exista previsão de multa por litigância de má-fé, isso não significa que esta não possa ser sancionada. O Superior Tribunal de Justiça vêm decidindo ${ }^{74}$ que a interposição de recurso com caráter protelatório é capaz de afastar a necessidade de aguardar o trânsito em julgado para que se inicie o cumprimento da pena. Por fim, em ambas as esferas, a violação ao dever de boa-fé na esfera profissional pode dar origem à nulificação do ato ${ }^{75}$.

O dever constitucional de fundamentação das decisões judiciais tembém tem relação íntima com o princípio da publicidade dessas decisões. No entanto, para que a exposição fique mais clara, lógica e coerente, essa relação seré melhor explicada no item 2.3.2.4.

\subsubsection{Motivação e Estado Democrático de Direito}

Mais do que permitir o controle da decisão judicial pelo Poder Judiciário, a motivação permite o controle da decisão judicial por toda a população. ${ }^{76}$ É certo que esse controle não abre as portas para a impugnação dessa decisão, mas permite aos jurisdicionados verificar como o Poder Judiciário aplica o Direito. Isso lhes permite, por exemplo, eleger membros do Poder Legislativo que se disponham a mudar uma lei caso os jurisdicionados discordem

\footnotetext{
${ }^{73}$ Bueno, Cássio Scarpinella, Curso sistematizado de direito processual civil, v. 1, cit. n. 51, p. 135; Comentário ao artigo 458 in Código de Processo Civil Interpretado, MARCATO, Antonio Carlos (org.), São Paulo, Atlas, 2005, p. 1430.

${ }^{74} 5^{\text {a }}$ Turma, AgRg nos EDcl no AgRg no AREsp n. 222493, Rel. Min. Jorge Mussi, j. 20.6.2013, DJe 1.8.2013; $5^{\mathrm{a}}$ Turma, AgRg nos EDcl nos EDcl no AgRg no Ag n. 1020286, Rel. Min. CAMPOS MARQUES

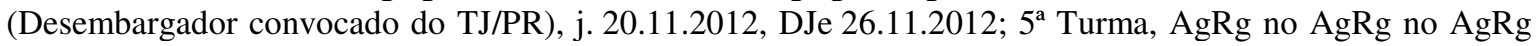
no Ag n. 1425288, Rel. Min. MARCo AurÉLIo BEllizZE, j. 25.9.2012, DJe 2.10.2012.

${ }^{75}$ CABRAl, Antonio do Passo, Nulidades no processo moderno: contraditório, proteção da confiança e validade prima facie dos atos processuais, cit. $n$. 70, pp. 234-235.

${ }^{76}$ BARbosa MOREIRA, José Carlos, A motivação das decisões judiciais como garantia inerente ao Estado de Direito, A motivação das decisões judiciais como garantia inerente ao Estado de Direito in Revista Brasileira de Direito Processual, v. 16, Rio de Janeiro, Forense, 1978, pp. 117-119; GARCIA, André Almeida, Prova Civil, cit. n. 51, p. 81; CADIET, Loïc; MEKKI, Soraya Amrani; e NoRMAND, Jacques, Théorie générale du procès, cit. n. 51, p. 679; SouZA, Wilson Alves de, Sentença civil imotivada: caracterização da sentença civil imotivada no direito brasileiro, cit. n. 51, p. 198; GRECO, Leonardo, Garantias fundamentais do processo: o processo justo, cit. $n .69$, p. 32.
} 
da aplicação que os juízes dão à lei. Há, assim, um controle da legitimidade do Poder Judiciário. Finalmente, a motivação permite orientar a ação futura das partes e dos jurisdicionados, pois mostra à sociedade como é aplicado o direito. ${ }^{77}$

Para entender melhor a função da motivação no Estado Democrático de Direito, são necessários alguns esclarecimentos iniciais sobre a legitimidade da ação estatal (item 2.3.2.1). A partir dos conceitos expostos nesse item, serão analisados dois fenômenos da organização e atuação estatal relevantes para a configuração do dever de fundamentação das decisões judiciais: a desconcentração do núcleo de tomada de decisões políticas (item 2.3.2.2) e o surgimento da democracia deliberativa (item 2.3.2.3). Com base nesses dois fenômenos será possível explicar o dever de fundamentação como instrumento para o controle democrático da decisão judicial (item 2.3.2.4) e, por fim, as consequências dessa última concepção (item 2.3.2.5)

\subsubsection{Estado moderno e legitimidade}

Antes de analisar a questão da legitimidade no Estado Democrático de Direito cabem algumas considerações quanto ao surgimento e evolução do Estado moderno, classe dentro da qual se insere o Estado Democrático de Direito. WEBER associa o surgimento do capitalismo moderno ao surgimento do Estado nacional fechado ao dizer que a disputa pelo capital entre os Estados nacionais fechados no Ocidente refletiu a disputa pelo poder entre esses Estados. Como esse capital podia estabelecer-se onde quisesse, podia determinar as condições para escolher entre Estados. Sob essas condições nasce a classe burguesa nacional e, como consequência, o capitalismo moderno. ${ }^{78}$

Após essas considerações, WEBER retoma alguns conceitos já estabelecidos por ele em Economia e sociedade. O Estado é, assim, definido como a comunidade humana que, dentro de determinado território, exerce monopolisticamente a coação física legítima. Quanto à legitimidade, lembra que existem três tipos ideais de dominação legítima, a dominação tradicional, que se exerce com base em algum costume (no sentido jurídico)

\footnotetext{
${ }^{77}$ CADIET, Loïc; MEKKI, Soraya Amrani; e NoRMAND, Jacques, Théorie générale du procès, cit. n. 51, p. 679; GUINCHARD, Serge et al, Droit processuel: droits fondamentaux du procès, cit. $n .51$, p. 1007; SoUZA, Wilson Alves de, Sentença civil imotivada: caracterização da sentença civil imotivada no direito brasileiro, cit. n. 51, p. 198.

${ }^{78}$ Wirtschaft und Gesellschaft: Grundiss der versteheden Soziologie, cit. n. 66, p. 517.
} 
sagrado; a dominação carismática, que se exerce com base na admiração ou confiança dos dominados em um líder em virtude de algum dom de graça pessoal e excepcional (e.g. representante eleito por meio de sufrágio); e a dominação racional, que se exerce com base na crença na validade de regras racionalmente criadas.

Após essa retomada, são feitas algumas considerações quanto às manifestações externas de uma organização de dominação política. Toda organização de dominação política que se protraia no tempo requer a obediência de pessoas diante daqueles que reclamam para si o poder legítimo (o quadro administrativo pessoal) e, mediante essa obediência, a disposição sobre os bens materiais que serão necessários para a aplicação da coação física toda vez que essa se fizer necessária (os recursos administrativos materiais). Vale notar que o quadro administrativo não obedece a quem detém o poder em virtude de sua legitimidade, mas em virtude de interesses pessoais, que se traduzem em recompensa material e honra social.

Os bens materiais de uma organização de dominação política podem pertencer total ou parcialmente aos membros do quadro administrativo, caso no qual essa associação é organizada estamentalmente. Nessa organização estamental, o detentor do poder político tem que dividi-lo com o quadro administrativo. Quando os bens materiais de uma organização política pertencem unicamente a essa organização política, ela detém monopolisticamente o poder político. É o que ocorre na ordem estatal burocrática do Estado moderno, no qual o domínio efetivo é exercido pelos funcionários burocráticos. Assim, o Estado moderno comporta-se de maneira análoga à moderna empresa capitalista ao separar o quadro administrativo de recursos administrativos, da mesma maneira que a empresa separa o trabalhador dos bens materiais do empreendimento.

Caracterizado o Estado moderno, WEBER passa a tecer algumas considerações tais como a que o Estado evolui inevitavelmente em direção ao funcionalismo burocrático, que tem como características: "contrato, salário, pensão, carreira, treinamento especializado e divisão do trabalho, competências fixas, documentação e ordem hierárquica”. Essa evolução do Estado em direção ao Estado burocrático favorece o desenvolvimento capitalista moderno que requer previsibilidade da atividade estatal, administrativa ou judiciária. Essa previsibilidade num sistema de "civil law", por sua vez, depende de 
motivação convincente nas decisões do quadro administrativo, ${ }^{79}$ com base no direito racional, que também é previsível. ${ }^{80}$

\subsubsection{Desconcentração do núcleo de tomada de decisões políticas}

O subsequente desenrolar da História demonstrou a acuidade da construção sociológica de WEBER. O Estado moderno realmente evoluiu no sentido de o funcionalismo burocrático ganhar cada vez mais poder. ${ }^{81}$ A própria evolução do Estado moderno para o Estado Social fez com que o juiz passasse a ter que fazer mais escolhas. ${ }^{82}$ Isso porque, diante de situações mais complexas e objetivos concorrentes, passou a ser necessário o recurso cada vez mais frequente a conceitos jurídicos abstratos e cláusulas abertas, como solução de compromisso do legislador, ${ }^{83}$ que trasferiu a decisão e seus custos políticos ao Judiciário. ${ }^{84}$ Consequência lógica necessária dessa necessidade de o Judiciário realizar escolhas é a necessidade de justificá-las, ${ }^{85}$ uma vez que, legitimando-se pela racionalidade, deve justificar racionalmente suas escolhas. ${ }^{86}$

Isso se vê nos dias atuais no fato de cada vez mais as grandes decisões que afetam os rumos da sociedade serem tomadas por funcionários burocráticos, sejam eles membros da Administração (e.g. decisão dos membros do COPOM quanto à taxa SELIC) ou membros do Judiciário (e.g. as decisões nos casos do abortamento de anencéfalos, ${ }^{87}$ utilização de células tronco embrionárias ${ }^{88}$ e união estável homoafetiva). ${ }^{89}$

\footnotetext{
${ }^{79}$ Idem, pp. 525-531.

${ }^{80}$ Idem, pp. 518-519.

${ }^{81}$ Idem, p. 531.

82 DutRA, Carlos Roberto de Alckmin, O controle abstrato de constitucionalidade sob o enfoque dos princípios processuais, Dissertação (Mestrado) - Faculdade de Direito de USP, São Paulo, 2010, pp. 209217; GoMES FILHO, Antonio Magalhães, A motivação das decisões penais, cit. n. 24, p. 11.

${ }^{83}$ O legislador, para evitar os custos políticos da decisão, passa a realizar, com cada vez mais frequência, compromissos formais dilatórios. Assim, em vez de decidir de forma definitiva sobre o conflito entre dois objetivos do Estado, utiliza-se de termos vagos para transferir a decisão ao Judiciário, conforme PORSCHER, Ralf, Ambiguity and Vagueness in Legal Interpretation cit. n. 11, pp. 34-36.

${ }^{84}$ GOMES FILHO, Antonio Magalhães, A garantia da motivação das decisões judiciais na Constituição de 1988, cit. n. 21, pp. 59-60.

${ }^{85}$ Mahmoud, Mohamad Ale Hasan e MourA, Maria Thereza Rocha de Assis, Motivação da sentença condenatória e o habeas corpus perante o Superior Tribunal de Justiça in A renovação processual penal após a Constituição de 1988, Lumen Juris, Rio de Janeiro, 2009, p. 218; CoMOGLIO, Luigi Paulo, Lezione sul processo civile, Bologna, Il Mulino, 1995, pp. 81-82

${ }^{86}$ GOMES FILHO, Antonio Magalhães, A motivação das decisões penais, cit. $n$. 24, p. 14.

${ }^{87}$ ADPF 54.

${ }^{88}$ ADI 3510.

${ }^{89}$ ADI 4277 e ADPF 132.
} 
Desses casos o que mais demonstra a deslocação do poder daqueles que detêm o poder legítimo através do carisma (os mandatários eleitos em um Estado moderno) para aqueles que detêm o poder legítimo através da racionalidade (os funcionários burocráticos em um Estado moderno) talvez seja o da ADPF 132. Essa Arguição de Descumprimento de Preceito Fundamental foi ajuizada pelo Governador do Estado do Rio de Janeiro para que fossem equiparadas as uniões homoafetivas às uniões estáveis para efeitos de aplicação de normas do Estatuto dos Servidores Públicos do Estado do Rio de Janeiro. ${ }^{90}$ Ora, tratandose do Estatuto dos Servidores Públicos do Estado do Rio de Janeiro, o Governador poderia utilizar-se de sua base política na Assembleia Legislativa para alterá-lo. Não o fez porque se trata de questão extremamente polêmica na sociedade brasileira e, a exemplo de outras questões polêmicas, deixou-se que o funcionalismo burocrático sobre ela decidisse.

A transferência das decisões políticas para o Poder Judiciário não decorre somente da inércia ou adoção de soluções de compromisso pelo legislador. O controle de constitucionalidade já transferiu parcela importante das decisões políticas ao Poder Judiciário. Nessas ações de controle de constitucionalidade, a importância do dever de fundamentar as decisões amplia-se, e deve permitir o controle da decisão pela população de tal maneira que seja tão legítima quanto a lei que se pretende declarar inconstitucional. Isso porque a decisão que declara inconstitucional uma lei é contramajoritária e, por isso, só poderá se legitimar por meio de fundamentação lógico-racional. ${ }^{91}$

Dentro desse quadro de transferência das mais importantes decisões de uma comunidade política para o funcionalismo burocrático é necessário que esse funcionalismo aja legitimamente. Ora, se a burocracia se legitima através da racionalidade é necessário que demonstre essa racionalidade, o que leva ao dever de fundamentar as decisões judiciais. ${ }^{92}$

Na realidade, tamanha é a relevância da legitimidade racional no Estado contemporâneo que até os membros do Legislativo, que já são legitimados carismaticamente por meio do

\footnotetext{
${ }^{90}$ Decreto-Lei no $220 / 75$.

${ }^{91}$ DUTRA, Carlos Roberto de Alckmin, O controle abstrato de constitucionalidade sob o enfoque dos princípios processuais, cit. $n$. 82 , pp. 218-219. Nesse sentido a afirmação de que "O parlamento representa o povo politicamente, o tribunal argumentativamente", ALEXY, Robert, Direitos fundamentais no Estado constitucional democrático. Para a relação entre direitos do homem, direitos fundamentais, democracia e jurisdição constitucional, trad. port. de Heck, Luís Afonso in Revista Direito Administrativo, n. 217, Rio de Janeiro, 1999, pp. 55-56. A Corte Constitucional é bem sucedida ao representar argumentativamente o povo quando é capaz de convencê-lo com seus argumentos

92 Nessa perspectiva, existiria também o dever de fundamentação dos atos administrativos, tema relevante, mas que foge do escopo deste trabalho. Para uma abordagem aprofundada sobre o tema, CINTRA, Antônio Carlos de Araújo, Motivo e motivação do ato administrativo, São Paulo, RT, 1979.
} 
sufrágio, buscam a legitimação racional. É o que acontece toda vez que justificam a opção legislativa realizada por meio da exposição de motivos $^{93}$.

Além de legitimar a atuação estatal por meio do Poder Judiciário, a motivação permite controlar essa desconcentração do núcleo de tomada de decisões políticas para que esta não se degenere em usurpação de competências. Nesse sentido, ela garante a separação dos poderes. $^{94}$

\subsubsection{Motivação e democracia deliberativa}

O dever de fundamentação das decisões judiciais deve ser entendido não só sob a ótica da desconcentração dos centros de decisão no Estado moderno, mas também sob a ótica da transformação da democracia participativa em democracia deliberativa. ${ }^{95}$ Nesse sentido, a democracia não se esgota com a participação do povo na eleição de seus representantes, mas deve garantir a possibilidade de o povo deliberar diretamente na tomada de decisões pelo Estado. ${ }^{96}$

Ao possibilitar que se afira se foi garantido às partes o direito de valer suas razões em juízo, a motivação legitima o exercício do poder pelo Poder Judiciário em um Estado Democrático de Direito. O direito de valer suas razões em juízo, no entanto decorre não só do direito de ação, mas do próprio princípio democrático.

Só é legítima, em uma democracia, uma decisão participada. Nos Poderes Executivo e Legislativo, essa participação se dá por meio do voto. Assim, todas as decisões tomadas pelos governantes que fazem parte desses Poderes legitimam-se porque foram tomadas por aqueles a quem o povo democraticamente deu poderes de representá-lo. A participação, portanto, é indireta.

\footnotetext{
${ }^{93}$ GoMEs FILHO, Antonio Magalhães, A motivação das decisões penais, cit. n. 24, pp. 77-78.

${ }^{94}$ Idem, pp. $90-91$.

${ }^{95}$ LeITE, Lúcia Maria de Figueiredo Ferraz, A participação do cidadão na Administração Pública no direito brasileiro. O papel do Ministério Público, Dissertação - Mestrado, Faculdade de Direito da Universidade de Lisboa, Lisboa, 2005, p. 43.

${ }^{96}$ CABRAL, Antonio do Passo, Nulidades no processo moderno: contraditório, proteção da confiança e validade prima facie dos atos processuais, cit. n. 70, pp. 106-111; GOMES FILHO, Antonio Magalhães, A motivação das decisões penais, cit. n. 24, pp. 39; 41.
} 
A situação do Poder Judiciário é diferente dos demais e, de certa maneira, paradoxal. De um lado, os membros do Poder Judiciário não são eleitos democraticamente, ou seja, o povo não lhes deu poderes para representá-lo. De outro lado, o Poder Judiciário é o único que, por sua própria função, está diariamente em contato com o povo, que permite que a participação seja direta.

Para que essa participação ocorra, no entanto, ela deve ser efetiva e não fictícia. Ou seja, deve ser garantido às partes que, toda vez que uma decisão do Poder Judiciário possa afetar sua esfera privada de interesses, sua vontade seja efetivamente levada em conta na decisão, que, assim, torna-se uma decisão participada e, portanto legítima. ${ }^{97}$ Só é possível, no entanto, dizer que a vontade da parte foi levada em conta na tomada de decisão se o conteúdo da motivação for condicionado pelo contraditório ${ }^{98}$ - que é visto, portanto, como direito de influência.

\subsubsection{Motivação e controle democrático da decisão}

Ou, seja, em um Estado Democrático de Direito com tendências cada vez mais burocráticas, a motivação deixa de refletir somente a preocupação de racionalizar a atividade jurisdicional. ${ }^{99}$ Passa a abranger também a necessidade de demonstração e controle de todos os atos dos poderes constituídos, que devem, por isso ter premissas de índole cognitiva, não de índole potestativa. ${ }^{100}$

Nessa perspecitva, os detentores do poder têm o obrigação de prestar contas do exercício desse poder, que lhes é delegado pelo povo. ${ }^{101}$ No Estado Democrático de Direito, qualquer intromissão estatal na esfera jurídica dos indivíduos - inclusive a jurisdicional -

\footnotetext{
${ }^{97}$ Gomes FILHO, Antonio Magalhães, A garantia da motivação das decisões judiciais na Constituição de 1988, cit. n. 21 , p. 60.

${ }^{98}$ GoMes FILHO, Antonio Magalhães, A motivação das decisões judiciais na Constituição de 1988: funções políticas e processuais, cit. n. 53, p. 19; Provas in As Reformas no processo penal, MouRA, Maria Thereza Rocha de Assis (org.), São Paulo, RT, 2008, p. 250; A garantia da motivação das decisões judiciais na Constituição de 1988, cit. n. 21, p. 60; TUCCI, José Rogério Cruz e, Garantias constitucionais da publicidade dos atos processuais e da motivação das decisões no Projeto de CPC, cit n. 60, pp. 17-18.

${ }_{99}$ BARBosa MoreIRA, José Carlos, A motivação das decisões judiciais como garantia inerente ao Estado de Direito, cit. n. 76, p. 114.

${ }^{100}$ Almada, Roberto José Ferreira de, A garantia processual da publicidade, São Paulo, RT, 2006, p. 16.

${ }^{101}$ DuTRA, Carlos Roberto de Alckmin, $O$ controle abstrato de constitucionalidade sob o enfoque dos princípios processuais, cit. $n .82$, p. 206.
} 
deve ser justificada material - existe fundamento para a intromissão - e formalmente - o fundamento é declarado. ${ }^{102}$

Há, no dever de fundamentação das decisões judiciais e no princípio da publicidade ${ }^{103}$ das mesmas uma dupla legitimação da atuação jurisdicional. ${ }^{104} \mathrm{~A}$ publicidade legitima, pelo procedimento, as decisões tomadas pelo Poder Judiciário, uma vez que permite possibilita a participação do Povo, ${ }^{105}$ ao passo que a fundamentação legitima essa decisão pela demonstração de sua racionalidade.

No Estado Democrático de Direito, o dever de fundamentação das decisões judiciais, passa a ser visto sob a ótica da disciplina da atividade estatal como garantia fundamental dos indivíduos. ${ }^{106}$ Está, portanto, ligado à ideia de que as decisões judiciais devem ser controladas não só por outros magistrados — através dos mecanismos endoprocessuais — mas por toda a sociedade. ${ }^{107}$ Esse controle extraprocessual das decisões judiciais pelos jurisdicionados ${ }^{108}$ fortalece a confiança da sociedade na tutela jurisdicional.

\footnotetext{
${ }^{102}$ BARbOSA Moreira, José Carlos, A motivação das decisões judiciais como garantia inerente ao Estado de Direito, cit. n. 76, p. 117; GOMES FILHO, Antonio Magalhães, A motivação das decisões penais, cit. $n$. 24, pp. 75-76; A motivação das decisões judiciais na Constituição de 1988: funções políticas e processuais, cit. n. 53, p. 16; A garantia da motivação das decisões judiciais na Constituição de 1988, cit. n. 21, p. 60.

${ }^{103} \mathrm{O}$ mesmo texto normativo (art. 93, IX, CF) traz a garantia de fundamentação e a garantia de publicidade das decisões judiciais.

${ }^{104}$ GOMES FILHO, Antonio Magalhães, A motivação das decisões penais, cit. $n$. 24, pp. 104-105.

${ }^{105}$ LUHMAN, Niklas, Legitimação pelo procedimento, trad. port. Côrte-Real, Maria da Conceição, Brasília, UnB, 1980, p. 105 apud DuTRA, Carlos Roberto de Alckmin, O controle abstrato de constitucionalidade sob o enfoque dos princípios processuais, cit. $n .82$, p. 217.

${ }^{106}$ Barbosa MoreIRA, José Carlos, A motivação das decisões judiciais como garantia inerente ao Estado de Direito, cit. n. 76, pp. 115-116.

${ }^{107}$ BARBOSA MOREIRA, José Carlos, A motivação das decisões judiciais como garantia inerente ao Estado de Direito, cit. n. 76, p. 118; GRECO, Leonardo, Garantias fundamentais do processo: o processo justo, cit.n. 69, p. 32; GARCIA, André Almeida, Prova Civil, cit. n. 51, p. 81; CADIET, Loïc; MeKKI, Soraya Amrani; e NoRMAND, Jacques, Théorie générale du procès, cit. n. 51, p. 679; SouZA, Wilson Alves de, Sentença civil imotivada: caracterização da sentença civil imotivada no direito brasileiro, cit. $n$. 51 , p. 198; FRANCO, Fernão Borba, Aproximação entre processo judicial e administrativo: um enfoque sobre o procedimento e a motivação, cit. $n .51$, p. 182; TARUFFO, Michele, La motivazione della sentenza civile, cit. n. 1, pp. 405-407; TuCCI, José Rogério Cruz e, A motivação da sentença no processo civil, cit. n. 3, pp. 2324; Garantias constitucionais da publicidade dos atos processuais e da motivação das decisões no Projeto de CPC, cit n. 60, p. 117; BADARÓ, Gustavo Henrique Righi Ivahy, Vícios de motivação da sentença penal: ausência de motivação, motivação contraditória, motivação implícita e motivação per relationem, cit. $n$. 21 , pp. 125-126; GOMES FILHO, Antonio Magalhães, A motivação das decisões penais, cit. n. 24, pp. 48-49; 80; A garantia da motivação das decisões judiciais na Constituição de 1988, cit. n. 21 , p. 68.

${ }^{108}$ Esse controle das decisões judiciais pelos jurisdicionados não significa que o Poder Judiciário deva decidir conforme a vontade da opinião pública, mas tão-somente que esta deve ser enxergada como destinatária da motivação das decisões judiciais.
} 
Ao se colocar a justificativa do dever de motivar as decisões judiciais não só sob a ótica de racionalização da atividade jurisdicional, mas também sob a ótica de garantia individual, fica evidente a necessidade de motivação também das decisões não impugnáveis. Isso por que, sendo essas decisões destinadas a prevalecer definitivamente, maior a intromissão que representam na esfera jurídica dos indivíduos e, portanto maior a importância da justificação da intromissão estatal. ${ }^{109}$

\subsubsection{Controle democrático da decisão e conteúdo da motivação}

O controle democrático das decisões judiciais possibilitado por sua justificação e publicidade significa a participação popular na administração da justiça em seu momento culminante, a decisão. $\mathrm{O}$ fato de o controle democrático das decisões judiciais só ser exercido em pouco casos (no caso brasileiro, imagine-se o julgamento do Mensalão ou o julgamento sobre o aborto de fetos anencéfalos) não diminui a importância dessa configuração do dever de fundamentação. Isso porque o que importa é que a fundamentação possibilita o controle democrático das decisões judiciais, não que esse controle efetive-se na prática. ${ }^{110}$

Essa concepção do dever de fundamentação das decisões judiciais influencia o conteúdo necessário dessa fundamentação. Para ser possível o controle democrático das decisões estatais, o conteúdo da motivação deve ser completo, no sentido de que os todos os elementos que racionalizem a decisão devem ser expressos e justificados. Assim, as escolhas que levaram à decisão final devem ser expressas e os critérios que levaram a essas escolhas devem poder ser determinados.

A definição do significado da motivação deve integrar a definição estrutural do conceito (Capítulo 3) com o significado que assume em sua relevância constitucional. Dessa maneira, o conteúdo mínimo da motivação - suficiente para que esta possa ser considerada válida - deve também ser extraído de sua estrutura e da sua função constitucional, bem como de sua função endoprocessual. ${ }^{111}$

\footnotetext{
${ }^{109}$ BARbOSA MoreIRA, José Carlos, A motivação das decisões judiciais como garantia inerente ao Estado de Direito, cit. n. 76, p. 118-120.

${ }^{110}$ TARUFFO, Michele, La motivazione della sentenza civile, cit. n. 1, pp. 407-409; GOMES FILHO, Antonio Magalhães, A garantia da motivação das decisões judiciais na Constituição de 1988, cit. n. 21, p. 60

${ }^{111}$ TARUFFO, Michele, La motivazione della sentenza civile, cit. $n$. 1, pp. 412-416.
} 


\subsubsection{Dever de motivação como regra constitucional}

Nos itens anteriores desta dissertação, utilizou-se a expressão "dever de fundamentação das decisões judiciais" ou outras semelhantes para se referir ao objeto desta análise. A utilização dessa expressão foi consciente, para evitar a utilização da expressão "princípio da motivação", mais comum na doutrina.

A expressão "princípio da motivação" foi até agora evitada porque é uma expressão carregada de sentido, mesmo que não se perceba. Assim, ao se caracterizar a motivação como princípio, remete-se à extensa doutrina sobre teoria dos princípios, ${ }^{112}$ que se insere na ainda mais extensa doutrina sobre a teoria das normas. ${ }^{113}$

A justificação da superioridade de uma teoria normativa sobre as demais é atividade extremamente complexa, digna de um estudo que se dedique exclusivamente a ela. Por esse motivo, e para não perder o escopo desta dissertação, a adoção da teoria dos princípios de AleXy é uma premissa que não será discutida. Assim, será apresentada a teoria dos princípios de ALEXY (item 2.3.3.1) e serão discutidas as consequências da adoção dessa teoria para a definição da estrutura da norma que veicula o dever de fundamentação das decisões judiciais (item 2.3.3.2).

\subsubsection{A teoria dos princípios de AlEXY}

A teoria de ALEXY se funda na distinção entre regras e princípios que são, ambos, normas, porque dizem o que deve ser. ${ }^{114}$ São, no entanto normas qualitativamente (ontologicamente) diferentes, pois existe um critério ${ }^{115}$ que as distingue com precisão.

\footnotetext{
${ }^{112}$ Ver, por exemplo, LARENZ, Karl, Methodenlehre der rechtswissenschaft, Berlin, Springer, 1960, trad. port. de Lamego, José, Metodologia da ciência do direito, $3^{\mathrm{a}}$ ed., Lisboa, Fundação Calouste Gulbenkian, 1997; ÁvILA, Humberto, Teoria dos princípios: da definição à aplicação dos princípios jurídicos, São Paulo, Malheiros, 2010; DwORKIN, Ronald, Taking rights seriously, Cambridge, Harvard University, 1977, trad. port. de Boeira, Nelson, Levando os direitos a sério, São Paulo, Martins Fontes, 2002.

${ }^{113}$ Como a paradigmática concepção kelseniana que não distingue regras de princípio, KELSEN, Hans, Reine rechtslehre, Franz Deuticke, Wien, 1960, trad. port. de Machado, João Baptista, Teoria Pura do Direito, São Paulo, Martins Fontes, 2003.

${ }^{114}$ ALEXY, Robert, Theorie der Grundrecht, $5^{\mathrm{a}}$ ed., Berlim, Suhrkamp, 2006, trad. port. de Silva, Virgílio Afonso da, Teoria dos direitos fundamentais, São Paulo, Malheiros, 2008, pp. 86-87.

${ }^{115}$ A generalidade, conteúdo axiológico ou importância para o ordenamento não são critérios para diferenciar regras de princípios, Idem, pp. 108-109.
} 
Os princípios são conceituados como "normas que ordenam que algo seja realizado na maior medida possível dentro das possibilidades jurídicas e fáticas existentes". ${ }^{116}$ Quando se fala nas possibilidades jurídicas de realização de um princípio a referência são as regras e princípios colidentes. ${ }^{117}$ Regras "são normas que sempre são satisfeitas ou não satisfeitas. Se uma regra vale, então, deve se fazer exatamente aquilo que ela exige; nem mais, nem menos. Regras contêm, portanto, determinações no âmbito daquilo que é fático e juridicamente possível". ${ }^{118}$

Outra distinção entre essas classes de norma se deve ao fato de conflitos entre regras e colisões entre princípios solucionarem-se de forma distinta. No caso do conflito entre regras, ou se introduz uma cláusula de exceção em uma das regras ou se declara inválida uma das regras ${ }^{119}$. No caso da colisão entre princípios, um dos princípios prevalece sobre o outro sob determinadas condições. Assim, a solução da colisão não se opera somente no campo da validade como também no campo do "peso"120 que varia - para cada princípio caso a caso. ${ }^{121}$

De maneira mais precisa, a solução para a colisão entre princípios "consiste no estabelecimento de uma relação de precedência condicionada entre os princípios, com base nas circunstâncias do caso concreto". ${ }^{122}$ As condições de precedência de um princípio sobre o outro são também o suporte fático da regra que tem como consequência jurídica aquela do princípio prevalecente sob essas condições. ${ }^{123}$

Estabelecido como se solucionam os conflitos entre regras e colisões entre princípios, passa-se a explicar como se resolvem as colisões entre regras e princípios. Nessas colisões, para que o princípio prevaleça é necessário que prepondere não só sobre o princípio que materialmente sustenta a regra, mas também sobre o princípio segundo o qual as regras devem ser cumpridas, que sustenta formalmente essa regra (e todas as regras). ${ }^{124}$

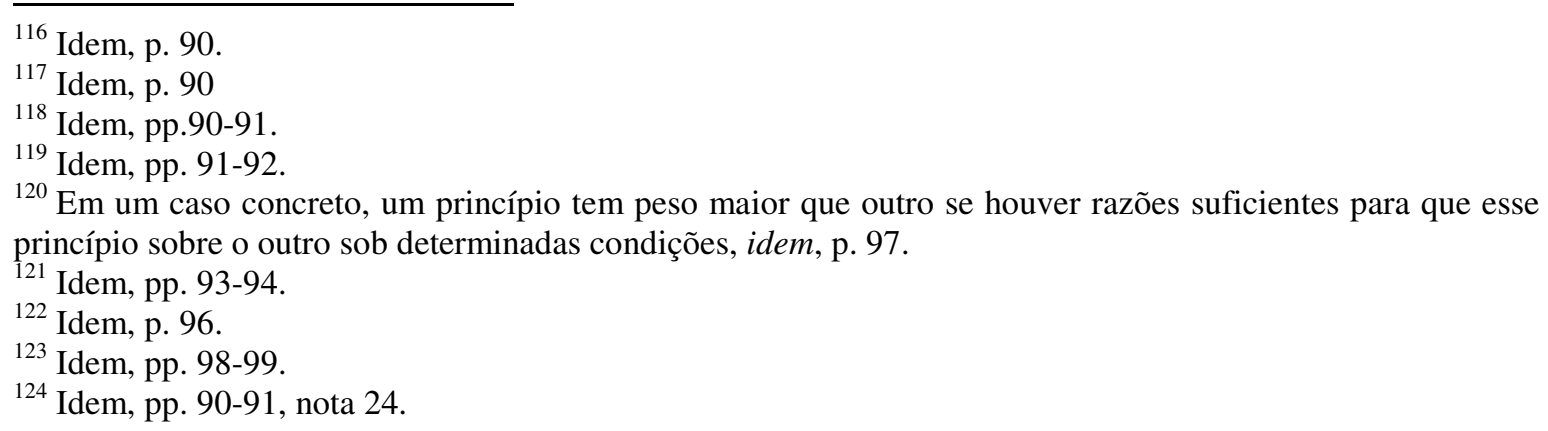


Quanto ao conteúdo dessas classes de norma, regras, ao contrário de princípios, determinam a extensão de seu conteúdo no âmbito das possibilidades fáticas e jurídicas. Isso significa, por um lado, que princípios não contêm mandamentos definitivos, mas prima facie. Por outro lado, disso não se pode inferir que regras têm um caráter estritamente definitivo, uma vez que podem ser introduzidas cláusulas de exceção - em número que não se pode previamente determinar - em virtude do conflito com outras normas - regras ou princípios. Isso significa que regras também contêm mandamentos prima facie, embora seu caráter prima facie seja diferente daquele dos princípios, em virtude das diferenças entre a colisão entre princípios e a colisão entre regras e princípios. $^{125}$

Quando da descrição da solução para a colisão entre princípios mencionou-se o peso dessas normas, devendo haver um sopesamento para solucionar essa colisão. Esse sopesamento é, como se pode ver, uma das máximas parciais que compõem a máxima da proporcionalidade, consequência da natureza dos princípios e vice-versa.

A máxima da proporcionalidade é dividida em três máximas parciais, da adequação, da necessidade e da proporcionalidade em sentido estrito. A máxima da proporcionalidade em sentido estrito decorre da limitação dos princípios em face das possibilidades jurídicas, uma vez que é necessário o sopesamento dos princípios colidentes. As máximas da necessidade e da adequação decorrem da limitação dos princípios em face das possibilidades fáticas. ${ }^{126}$

A máxima da proporcionalidade em sentido estrito, expressa por meio do sopesamento, dispõe que “(q)uanto maior for o grau de não-satisfação ou de afetação de um princípio, tanto maior terá que ser a importância da satisfação do outro". ${ }^{127}$ Segundo a máxima da necessidade, caso duas medidas sejam igualmente adequadas para promover um princípio e uma delas prejudique menos a promoção de outro princípio é essa medida que deve ser

\footnotetext{
${ }^{125}$ Idem, pp. 104-105.

${ }^{126}$ Idem, pp. 116-118.

${ }^{127}$ Idem, p. 167.
} 
escolhida. O exame da adequação verifica se determinada medida fomenta a realização de determinado princípio. $^{128}$

Finalmente, quanto à diferença entre princípios e valores, essa se deve ao fato de serem os princípios conceitos deontológicos e os valores, conceitos axiológicos. Apesar dessa diferença fundamental, tanto princípios como valores podem ser sopesados porque têm estrutura semelhante. ${ }^{129}$

\subsubsection{Regra da motivação}

Explicada a teoria normativa de ALEXY, cumpre analisar a norma contida no artigo 93, IX, ${ }^{130}$ da Constituição Federal sob essa ótica. Não serão analisadas concepções que se referem ao dever de motivar as decisões jurisdicionais como princípio da motivação sem que partam da teoria normativa de ALEXY ${ }^{131}$, uma vez que já partimos dessa premissa neste trabalho. Isso remete à construção de GUERRA, que também adota como pressuposto a teoria normativa de ALEXY. GUERRA se propõe a reconstruir o princípio da motivação a partir da ideia de que para compreender uma norma é necessário identificar a exata conduta comandada por ela. ${ }^{132}$ Para o autor, o sentido de uma norma estrutura-se em duas partes: a representação de uma conduta - componente representacional ${ }^{133}$ - e sua qualificação deôntica como devida - força ilocucionária.

\footnotetext{
${ }^{128}$ Idem, pp. 119-120.

${ }^{129}$ Idem, pp. 144-145, 147-151.

130 “Todos os julgamentos dos órgãos do Poder Judiciário serão públicos, e fundamentadas todas as decisões, sob pena de nulidade, podendo a lei limitar a presença, em determinados atos, às próprias partes e a seus advogados, ou somente a estes, em casos nos quais a preservação do direito à intimidade do interessado no sigilo não prejudique o interesse público à informação".

${ }^{131}$ V. Cintra, Antônio Carlos de Araújo; Grinover, Ada Pelegrini; DinAmarco, Cândido Rangel, Teoria Geral do Processo, cit. n. 51, p. 74; BUENO, Cássio Scarpinella, Curso sistematizado de direito processual civil, v. 1, cit. n. 51, p. 132; CARMONA, Carlos Alberto, Arbitragem e Processo: um comentário à Lei $n^{o}$ 9.307/96, cit. n. 60, p. 476; OlIVEIRA, Pedro Miranda de, Princípios constitucionais do processo civil no âmbito recursal, cit. n. 60, p. 565; DIAS, Ronaldo Brêtas de Carvalho, A fundamentação das decisões jurisdicionais no Estado Democrático de Direito in Processo e Constituição: estudos em homenagem ao professor José Carlos Barbosa Moreira, coordenação FUX, Luiz; NERY JUNIOR, Nelson; e WAMBIER, Teresa Arruda Alvim, São Paulo, RT, 2006, p. 568; TUCCI, José Rogério Cruz e, A motivação da sentença no processo civil, cit. n. 3; WAMBIER, Teresa Arruda Alvim, Omissão judicial e embargos de declaração, São Paulo, RT, 2005, pp. 293-350; BARBosA MoreIRA, José Carlos, A motivação das decisões judiciais como garantia inerente ao Estado de Direito, cit. n. 76.

${ }^{132}$ GUERRA, Marcelo Lima, Notas sobre o dever constitucional de fundamentar as decisões judiciais (CF, art. 93, IX) in Processo e Constituição: estudos em homenagem ao professor José Carlos Barbosa Moreira, coordenação FuX, Luiz; NERY JUNIOR, Nelson; e WAMBIER, Teresa Arruda Alvim, São Paulo, RT, 2006, p. 518.

${ }^{133} \mathrm{O}$ autor considera que o componente representacional fixa as condições de satisfação da norma, Idem, p. 518 .
} 
Como o autor busca um modelo normativo de decisão fundamentada relativizado ao ordenamento brasileiro, ele busca nesse ordenamento - em virtude do postulado de racionalidade do legislador - os dados necessários à elaboração do modelo, uma vez que não é possível fixar a conduta tida como devida pelo artigo 93, IX, da Constituição Federal pelo próprio texto legal. É possível, no entanto, inferir desde já que são os juízes os destinatários na norma prevista no artigo 93, IX, da Constituição Federal. ${ }^{134}$

Com base em análise lógica das possibilidades semânticas, chega-se à conclusão de que a decisão fundamentada almejada pelo constituinte é o resultado do ato de decidir acompanhada das razões que o qualifiquem como correto, sendo a decisão ontologicamente diferente de seu fundamento, em virtude do artigo 458 do Código de Processo Civil, que os qualifica como (diferentes) elementos da sentença. Esse mesmo dispositivo prevê que nos fundamentos o juiz analisa e no dispositivo resolve questões não necessariamente coincidentes.

A análise da questão, que corresponde à fundamentação da decisão, deve ser entendida como a determinação intelectiva da solução mais correta entre as possíveis para a questão em apreço, enquanto no dispositivo da sentença ocorre a adoção dessa solução. A correção de uma decisão, por sua vez depende de sua conformidade a certos critérios de correção.

$\mathrm{O}$ autor, então, determina quais são as questões que o juiz está autorizado a resolver e conclui - com base no artigo $5^{\circ}$, XXXV da Constituição Federal c/c artigos $4^{\circ}$ e 459 , ambos do Código de Processo Civil — que são as que digam respeito à declaração de existência ou de inexistência de direito subjetivo do qual o autor alegue ser titular. Isso leva à conclusão de que nos fundamentos o juiz deve determinar cognitivamente se a solução correta é a declaração de existência ou de inexistência do direito subjetivo do qual o autor alegue ser titular. Em virtude disso, os critérios de correção, que determinam a correção de uma decisão dependem das condições de existência do direito subjetivo pleiteado.

As condições de existência de um direito subjetivo, por sua vez, são a existência de uma norma que descreva um fato como condição de sua incidência - e de existência do direito

${ }^{134}$ Idem, pp. 518-521. 
subjetivo - e a ocorrência do fato descrito. Daí que é correta a declaração de existência de um direito subjetivo se forem corretas a declaração de existência dessa norma e a declaração de ocorrência desse fato. Essas declarações podem, elas próprias, ser corretas ou incorretas e, por isso, dependem de fundamentação, o que significa que têm seus próprios critérios de correção.

Os critérios de correção das declarações de existência de norma são a declaração de que a norma em questão é o sentido veiculado pelo texto legislativo trazido à análise e a declaração de que o ato legislativo que produziu esse texto é válido. Essas declarações, de maneira similar ao exposto no parágrafo anterior, podem ser corretas ou incorretas e por isso devem observar seus próprios critérios de correção, sem que seja possível visualizar o ponto no qual os critérios de correção não precisem, eles próprios, observar critérios de correção ${ }^{135}$

Para chegar aos critérios de correção ${ }^{136}$ das declarações de ocorrência de fatos, o autor percorre caminho um pouco mais longo. Preliminarmente, adota uma concepção semântico-pragmática da verdade, segundo a qual uma declaração é verdadeira quando a descrição nela contida corresponda ao que ocorreu. Constata, então, que a ocorrência de um fato é confirmada ao juiz mediante a representação de sua ocorrência por meio de provas, que devem ser usadas como critério de correção do juiz para que valham como razão que qualifica como correta a declaração de ocorrência do fato.

A representação de ocorrência de um fato através de um meio de prova não pode - por si própria e por seus próprios atributos - ser considerada como bastante para demonstrar a ocorrência do fato. É necessário também que o meio de prova seja confiável, o que leva à conclusão de que os critérios de correção da declaração de ocorrência de um fato são sua representação em determinado meio de prova e a confiabilidade desse meio de prova. Esses critérios de correção - da mesma maneira que os critérios de correção da declaração de existência de uma norma - são afirmações que podem ser corretas ou incorretas e que por isso devem observar seus próprios critérios de correção, não sendo possível visualizar

\footnotetext{
${ }^{135}$ Idem, pp. 521-528.

${ }^{136}$ A observância desses critérios de correção é necessária em virtude do fato de o juiz não costumar presenciar a ocorrência dos fatos alegados pelas partes, idem, p.528.
} 
o ponto no qual os critérios de correção não precisem, eles próprios, observar critérios de correção.

Diante do modelo apresentado, constata-se que existe a possibilidade de existirem infinitos níveis de fundamentação, o que leva ao problema do regresso ao infinito que, por sua vez, leva ao paradoxo de a norma veiculada pelo artigo 93, IX da Constituição Federal exigir conduta impossível de ser realizada. Para evitar esse paradoxo, são propostas duas soluções.

A primeira solução é interpretar a norma em questão não como um comando (ao juiz) a proferir decisões corretamente fundamentadas, mas como um comando a não proferir decisões equivocadamente fundamentadas, uma vez que é possível demonstrar que uma decisão é incorreta com um número finito de passos. ${ }^{137}$

Para demonstrar a incorreção dessa solução, basta imaginar a seguinte situação: desenvolveu-se perante o juiz um processo extremamente complexo, no qual são expostas teorias refinadas por ambas as partes, cada uma justificando a aplicação de uma norma e no qual foram realizadas diversas perícias de alta complexidade contraditórias entre si, divergindo as partes sobre qual perícia deve prevalecer. Caso seja adotada essa teoria, haveria decisão motivada caso o juiz dissesse simplesmente: "Ocorreu o fato $x$, que é previsto na norma $y$ e, por isso julgo procedente o pedido" (desde que efetivamente tenha ocorrido esse fato, ele seja a hipótese de incidência dessa norma e essa norma exista). Ora, apesar de ser possível imaginar que os tribunais nacionais aceitem tal sentença, é inaceitável que em um Estado Democrático de Direito as partes tenham que se contentar com essa sentença.

A segunda solução proposta por GUERRA para o (aparente) problema do regresso ao infinito da norma prevista pelo artigo 93, IX, da Constituição Federal consiste em considerar essa norma como um princípio no sentido que ALEXY dá ao termo. ${ }^{138} \mathrm{O}$

\footnotetext{
${ }^{137}$ Idem, pp. 528-533.

${ }^{138}$ Idem, p. 538.
} 
problema dessa solução nasce de uma leitura incorreta ${ }^{139}$ da obra de ALEXY e de uma utilização incorreta da linguagem.

Quanto à utilização incorreta da linguagem, o problema do regresso ao infinito, imaginado por GUERRA ${ }^{140}$ na realidade não existe. A ideia de que existem níveis infinitos de fundamentação, na verdade, contraria uma das premissas básicas da linguagem, segundo WITTGENSTEIN:

“6.5 Se uma resposta não pode ser posta em palavras, também não pode a pergunta. $\mathrm{O}$ enigma não existe. Se se pode de todo fazer uma pergunta então também se pode respondê-la.

6.5.1 O ceticismo não é irrefutável, mas obviamente falho de sentido por pretender por em dúvida o que não pode ser perguntado. E isto porque só pode haver dúvida onde pode haver pergunta, e uma pergunta só onde pode haver uma resposta, e esta só onde algo pode ser dito". ${ }^{141}$

Assim, se a motivação é um discurso (item 2.1.1.1) deve obedecer às regras da linguagem, que determinam que, em certo nível de abstração, o que se entende por "pergunta" deixa de sê-lo, isto é, deixa de fazer sentido como pergunta. Assim, não existe o problema do regresso ao infinito, o que permite considerar a motivação como um discurso finito e, mais do que isso descarta a necessidade de considerar que a norma veiculada pelo art. 93, IX, da Constituição Federal estrutura-se sob a forma de princípio.

Isso não significa, no entanto, que o dever de fundamentação das decisões judiciais estruture-se, necessariamente, sob a forma de regra. A estruturação desse dever como regra constitucional deve ser justificada argumentativamente. Para tal, será necessário o recurso a alguns exemplos.

Imagine-se que, primeiramente, uma comarca muito pequena e com pouco movimento judiciário, na qual um juiz se depare com a seguinte situação: só existe um processo em trâmite perante a vara de sua responsabilidade. Trata-se de ação de reconhecimento de

${ }^{139}$ GUERRA infere relações entre princípios e valores; afirma que normas de direitos fundamentais são, todas, princípios; e caracteriza os princípios como normas que veiculam comandos impossíveis de serem cumpridos integralmente, Idem, p. 534.

${ }^{140}$ Notas sobre o dever constitucional de fundamentar as decisões judiciais (CF, art. 93, IX) cit. n. 132, São Paulo, RT, 2006, pp. 531, 532.

${ }^{141}$ Tractatus logico-philosophicus, Routledge, London, 1922, trad. port. de Lourenço, M.S., Tratado lógicofilosófico, $3^{a}$ ed., Fundação Calouste Gulbenkian, Lisboa, 2002, p. 141. 
paternidade, na qual o réu não nega, em sede de contestação, que tenha mantido união estável com a genitora do autor na época de sua ${ }^{142}$ concepção, mas alega que o filho não é seu, pois teria sido traído e, por isso, abandonou o lar comum. Requer então a produção de prova pericial para que, por meio da realização de exame de DNA, seja provado que o autor não é seu filho. $\mathrm{O}$ autor, então, em sede de réplica, rebate as alegações do réu, mas concorda com a produção de prova pericial. O juiz terá, então, o prazo de 10 (dez) dias para proferir decisão relativa ao pedido de produção de prova pericial, em virtude do artigo 189, II do Código de Processo Civil. ${ }^{143}$

A norma prevista no artigo 189, II, do Código Civil é uma regra, ${ }^{144}$ que poderia ser considerada inválida caso um princípio colidente superasse - no caso concreto - em peso tanto o princípio que materialmente sustenta referida regra quanto o princípio segundo o qual as regras devem ser cumpridas, que sustenta formalmente essa regra. ${ }^{145}$ Quanto aos princípios que colidem materialmente nesse caso, é possível imaginar que sejam eles o princípio da celeridade processual ${ }^{146}$ e o "princípio" ${ }^{147}$ da motivação. Ora, o prazo estabelecido na referida regra representa um equilíbrio perfeitamente aceitável entre os dois "princípios" em questão, até porque, caso a regra prevista no artigo 189, II $^{148}$ do Código de Processo Civil fosse cumprida, os processos seriam mais céleres.

Pelos mesmos motivos que se concluiu que o artigo 189, II, do Código de Processo Civil é uma regra válida, é possível concluir que é legal que o juiz profira a decisão no último dia do prazo previsto pelo referido artigo, e que não é a prolação da decisão nesse termo que causa a morosidade processual que aflige nosso país.

Se o dever de motivar as decisões judiciais for um princípio, ele deve ser realizado "na maior medida possível dentro das possibilidades jurídicas e fáticas existentes". ${ }^{149}$ No

\footnotetext{
${ }^{142}$ Do autor.

${ }^{143}$ Não se vislumbra motivo para que seja aplicado ao caso o artigo 187 do Código de Processo Civil ("Em qualquer grau de jurisdição, havendo motivo justificado, pode o juiz exceder, por igual tempo, os prazos que este Código Ihe assina").

${ }^{144}$ Apesar de ser pouquíssimas vezes aplicada no dia-a-dia do foro.

${ }^{145}$ ALEXY, Robert, Theorie der Grundrecht, cit. n. 114, p. 90, pp. 90-91, nota 24

${ }^{146}$ Decorrente do artigo $5^{\circ}$, LXXVIII, da Constituição Federal.

${ }^{147}$ Por não termos ainda demonstrado que exigência de motivação das decisões judiciais é uma regra, ainda nos referiremos a ela como princípio. Caso tratásse-mo-la, desde já, como regra, o "princípio" da motivação deveria ser substituído, no exemplo, pelo princípio que sustenta materialmente a regra da motivação.

${ }^{148}$ Bem como os demais "prazos impróprios" previstos na legislação.

${ }^{149}$ ALEXY, Robert, Theorie der Grundrecht, cit. n. 114, p. 90.
} 
exemplo dado, as possibilidades jurídicas e fáticas existentes implicam que o juiz deve decidir em 10 dias (possibilidades jurídicas) sobre a realização de prova pericial em ação de reconhecimento de paternidade, que é a única em trâmite perante sua comarca (possibilidades fáticas).

Considerando o preparo que se exige de um juiz para que este ingresse na carreira, é de se supor que, em 10 dias, o juiz seja capaz de escrever um verdadeiro tratado versando a necessidade de produção de prova pericial em ação de reconhecimento de paternidade. Caso o dever de motivar as decisões judiciais seja um princípio, é exatamente isso que se exigiria do juiz no caso apresentado; que fundamentasse de maneira absolutamente exaustiva essa decisão.

Parece óbvio, no entanto, que não é isso que se exige do juiz. O que se exige do juiz, tanto no caso hipotético quanto em qualquer caso que possa ocorrer na prática é que a motivação das decisões judiciais seja suficiente (a suficiência da motivação será objeto do Capítulo 3).

Outro conflito de normas é apto a demonstrar que o dever, imposto ao juiz, de motivar suas decisões é veiculado por meio de uma norma que se estrutura como regra. Trata-se do conflito entre motivação e liberdade.

Primeiramente, é necessário estabelecer que a o direito à liberdade é veiculado por meio de norma que se estrutura sob a forma de princípio. Trata-se de premissa de fácil justificação: se houvesse uma regra que garantisse o direito à liberdade, todas as normas penais materiais seriam inconstitucionais, vez que preveem hipóteses de limitação da liberdade de ir e vir dos indivíduos. Ora, não parece razoável que se cogite da inconstitucionalidade de todas as normas penais, motivo pelo qual fica claro que o direito à liberdade é veiculado por meio de princípio.

O conflito entre motivação e liberdade - e suas consequências - fica claro na comparação entre a sentença penal absolutória e a sentença penal condenatória. Do ponto de vista do princípio da liberdade, é claro que entre as duas situações, a sentença penal absolutória promove na maior medida possível o princípio. 
Assim, caso a motivação fosse um princípio, seria aceitável que a sentença penal absolutória fosse menos motivada que a sentença penal condenatória ou até mesmo imotivada. Isso porque, do ponto de vista da proporcionalidade em sentido estrito, ${ }^{150}$ seria aceitável que, para promover intensamente a liberdade, se aceitasse que a sentença fosse menos motivada.

Não é, no entanto, o que ocorre. Nem o atual Código de Processo Penal ${ }^{151}$, nem o Projeto de Código de Processo Penal (Projeto de Lei do Senado n. 156/2009) ${ }^{152}$ tratam de maneira diferente o dever de motivação nas sentenças condenatórias e absolutórias, até porque não seria razoável fazê-lo. A sentença penal absolutória deve ser suficientemente motivada não só porque a motivação é regra ${ }^{153}$, mas também por conta das consequências da sentença penal no juízo cível. ${ }^{154}$ É exemplo claro da importância da motivação da sentença penal absolutória para o juízo cível o artigo 66 do Código de Processo Penal, que só impede o ajuizamento da ação civil para a reparação do dano quando a sentença tenha reconhecido a inexistência material do fato. A sentença penal absolutória também deve ser motivada para permitir que o Ministério Público possa recorrer da decisão. Por fim, a sentença penal absolutória deve ser motivada porque, como toda outra sentença - qualquer que seja sua natureza - , envolve escolhas discricionárias do juiz que, como membro do Estado, deve justificar suas ações, sob pena de minar a legitimidade do próprio Estado (supra 2.3.2).

Outra norma que possivelmente entraria em conflito com a regra da motivação é o princípio da intimidade garantido pelo artigo $5^{\circ}, X,{ }^{155}$ da Constituição Federal. Nessa perspectiva, a legislação francesa dispensa a motivação ${ }^{156}$ de decisões em processos de adoção ${ }^{157}$ ou de divórcio por culpa de um dos cônjuges ${ }^{158}$. Essas normas que preveem hipóteses de dispensa de motivação, no entanto, seriam inconstitucionais no Brasil.

\footnotetext{
${ }^{150}$ Não parece que esse conflito hipotético poderia ser resolvido segundo os critérios da necessidade ou da adequação.

${ }^{151} \mathrm{O}$ artigo 381 é aplicável tanto à sentença condenatória quanto à absolutória.

$152 \mathrm{O}$ artigo 417 é aplicável tanto à sentença condenatória quanto à absolutória.

${ }^{153} \mathrm{O}$ que não podemos tomar como premissa sob pena de tornar o raciocínio tautológico.

${ }^{154}$ GOMES FILHO, Antonio Magalhães, A motivação das decisões penais, cit. n. 24, p. 96; A motivação das decisões judiciais na Constituição de 1988: funções políticas e processuais, cit. $n .53$, p. 18.

155 "São invioláveis a intimidade, a vida privada, a honra e a imagem das pessoas, assegurado o direito a indenização pelo dano material ou moral decorrente de sua violação".

${ }^{156}$ CADIET, Loïc; MEKKI, Soraya Amrani; e NORMAND, Jacques, Théorie générale du procès, cit. $n .51, \mathrm{p}$. 687; GUINCHARD, Serge et al, Droit processuel: droits fondamentaux du procès, cit. $n .51$, p. 1010.

${ }^{157}$ Code Civil, art. 353, al. 5: "le jugement prononçant l'adoption n'est pas motivé".

${ }^{158}$ Code Civil, art. 248: "les débats sur la cause, les conséquences du divorce et les mesures provisoires ne sont pas publics" Code de Procédure Civile, art. 112: "la demande tendant à dispenser le juge aux affaires
} 
Não bastasse a própria Constituição Federal resolver o conflito entre o princípio da intimidade e a regra da motivação por meio de regras, ainda assim a regra da motivação prevaleceria sobre o princípio da intimidade em eventual conflito. Como já foi explicado, no caso de conflito entre regra e princípio, é necessário que o princípio prevaleça tanto sobre o princípio material que informa a regra quanto sobre o princípio formal segundo o qual as regras devem ser respeitadas para que a regra deixe de ser aplicada ao caso. ${ }^{159}$

No caso, o princípio material que sustenta a regra da motivação é o próprio princípio democrático (v. supra, 2.3.2). No conflito entre o princípio da intimidade e o princípio democrático, a dispensa de motivação das decisões em caso de adoção atende ao subcritério da adequação, pois fomenta a intimidade dos indivíduos. O subcritério da necessidade, no entanto, não é atendido, uma vez que existe uma maneira de preservar a intimidade do indivíduo com a mesma intimidade sem prejudicar o princípio democrático. Basta, para tanto, que se limite a publicidade do processo.

Essa é, como já se adiantou, a solução dada pelo próprio legislador constitucional para o problema. O artigo $5^{\circ}, \mathrm{LX},{ }^{160}$ e o próprio artigo $93, \mathrm{IX},{ }^{161}$ da Constituição Federal, contém normas — com a estrutura de regras — que dão a adequada solução à questão. Assim, toda vez que o princípio da intimidade puder ser atingido, permite-se a restrição à publicidade do processo, e única e exclusivamente à publicidade do processo.

O dever do juiz de motivar suas decisões, portanto, não pode ser restringido pelo princípio da intimidade, seja por expressa disposição constitucional, seja porque a interação entre a regra da motivação e o princípio da intimidade assim determina. Assim, normas que dispensassem o dever do juiz de motivar suas decisões em casos nos quais o princípio da intimidade poderia ser violado seriam inconstitucionais no Brasil.

familiales d'énoncer dans les motifs de sa décision les torts et griefs des époux doit être formulée de façon expresse et concordante dans les conclusions de l'un et l'autre époux".

${ }^{159}$ ALEXY, Robert, Theorie der Grundrecht, cit. n. 114, pp. 90-91, nota 24.

160 "A lei só poderá restringir a publicidade dos atos processuais quando a defesa da intimidade ou o interesse social o exigirem".

161 “Todos os julgamentos dos órgãos do Poder Judiciário serão públicos, e fundamentadas todas as decisões, sob pena de nulidade, podendo a lei limitar a presença, em determinados atos, às próprias partes e a seus advogados, ou somente a estes, em casos nos quais a preservação do direito à intimidade do interessado no sigilo não prejudique o interesse público à informação". 
A caracterização da norma que prevê o dever do juiz de motivar suas decisões como uma regra no sentido que lhe dá ALEXY é importante para a conclusão desta dissertação. Isso porque, determinados os contornos desse dever — tarefa que será objeto do Capítulo 3 -, não é possível flexibilizá-los. Assim, toda vez que as exigências decorrentes do dever do juiz de fundamentar suas decisões não forem observadas, as consequências descritas no Capítulo 5 deverão ocorrer automaticamente, e sem a análise de particularidades do caso concreto. 


\section{ESTRUTURA DA MOTIVAÇão}

Definida a função da motivação, é necessário analisar como ela cumpre essa função. Isso implica definir a estrutura da motivação. A reconstrução da estrutura da sentença dá-se de duas maneiras complementares. De um lado, identificam-se os tipos de proposição que compõem a sentença, de acordo com a natureza do juízo que exprimem e, de outro, identifica-se a função de cada proposição no conjunto que é a sentença.

A sentença é um conjunto de proposições estruturado de acordo com a função que deve desempenhar. Assim, a função que esse discurso (sentença) deve desempenhar determina não só os tipos de proposição que devem compô-la como também a forma que essas proposições devem interagir uma com a outra. ${ }^{162}$

\subsection{Estrutura e função da motivação}

Ao encarar a motivação como signo institucional, o que se enxerga é um instrumento de comunicação inserido em um processo comunicacional que tem o juiz como emissor e, como receptores, as partes e o público em geral. A interpretação da motivação como signo institucional distingue de sua interpretação como signo natural, entre outras coisas, por conta do objeto da interpretação.

O objeto da interpretação como signo institucional é a motivação em sua totalidade. Isso não significa, no entanto, que a motivação possa ser encarada como um signo atômico. Ela é um conjunto de signos cujo significado corresponde não só à soma dos significados dos signos que a compõem como também a um significado próprio desse conjunto, que leva em conta a função do discurso (conjunto de signos) e a influência que o contexto e a presença de outros signos têm na significação de cada signo.

O conjunto de signos que compõem a motivação organiza-se segundo um princípio ordenador de eficácia estruturante. A utilização da expressão "princípio" aqui não é acidental. Trata-se de verdadeiro princípio — isto é, um mandado de otimização —,

${ }^{162}$ TARUFFO, Michele, La motivazione della sentenza civile, cit. $n$. 1, pp. $37-38$ e n. 53. 
porque não impõe uma rígida concatenação lógica desses signos, mas que essa se dê na "maior medida possível".

O contexto é um sistema de correlações no qual um signo institucional se insere e influencia na determinação de seu significado. No caso da motivação, é importante notar o contexto no qual se insere, que é aquele da sentença. $\mathrm{O}$ contexto e, mais especificamente a correlação entre motivação e decisão determina a(s) função(ões) instrumental(is) que a motivação desempenha na sentença. Dentre essas funções destaca-se a função de justificação que a motivação tem em relação à decisão, o que determina que deva ser interpretada em atenção a essa função.

A estrutura interna da motivação deve, assim, levar em conta sua função de justificação. Isso impõe que as proposições que compõem a motivação devem se organizar de acordo com uma ordem lógica de caráter justificativo. Isso resulta na presença, na motivação, de um conjunto ordenado de correlações lógicas entre as proposições, bem como na presença na motivação de componentes que não são lógicos, mas retórico-argumentativos.

O sistema lógico do discurso motivação consiste em articulações e concatenações de natureza - na maioria das vezes - inferencial orientadas para a função justificativa que o discurso exerce. Esse modo de organização do discurso é um critério de determinação do significado da motivação encarada como conjunto de signos, bem como o paradigma para a verificação se a motivação cumpriu sua função justificativa no contexto do discurso sentença.

A estrutura lógica da motivação funciona como critério para estabelecer o significado não só da motivação globalmente considerada, mas também das proposições que a compõem. Esse critério é capaz de atribuir diferentes significados a uma proposição (signo institucional) caso ela se insira nessa estrutura lógica como premissa ou consequência, por exemplo. $^{163}$

${ }^{163}$ Idem, pp. 108-113. 


\subsection{Teorias sobre a estrutura do raciocínio decisório e raciocínio justificativo}

Antes de apresentar uma teoria "nova" sobre a estrutura do raciocínio decisório e raciocínio jusitificativo é necessário analisar as teorias já existentes. Impõe-se, portanto, a análise da teoria do silogismo como estrutura do raciocínio do juiz (item 3.2.1) e das críticas a essa estrutura (item 3.2.2)

\subsubsection{O modelo silogístico}

Existem diversas teorias que buscam explicar o raciocínio decisório e a motivação. A teoria paradigmática, ${ }^{164}$ nesse ponto, é a teoria do silogismo judicial, que sofreu diversas críticas. Algumas dessas críticas deram origem a outras teorias como a tópica e a argumentativa. ${ }^{165}$

A teoria do silogismo - assim entendido como raciocínio dedutivo — , na realidade, não postula que o raciocínio do juiz seja composto de um único silogismo, mas de um polissilogismo, no qual a conclusão de um silogismo é a premissa do seguinte, até que todo o raciocínio esteja concatenado. ${ }^{166}$

A afirmação de que o silogismo judicial não representa o raciocínio decisório é feita tanto pelas teorias antirracionalistas quanto pelas teorias que se utilizam dos instrumentos da lógica, mas não os restringem ao silogismo. Esse segundo conjunto de teorias não rejeita a utilidade nem a aptidão do silogismo para representar determinados momentos do raciocínio decisório, mas identificam a insuficiência do silogismo para representar todo o raciocínio decisório. ${ }^{167}$

A teoria do silogismo pressupõe a coincidência entre a estrutura do raciocínio decisório e a estrutura do raciocínio justificativo (motivação), o que obscurece a questão de se tratar de uma teoria do raciocínio decisório, da motivação ou de ambos. Caso a teoria do silogismo seja uma teoria do raciocínio decisório, está errada, pois o raciocínio decisório não é

\footnotetext{
${ }^{164}$ CORRÊA, Orlando de Assis, Sentença cível: elaboração e nulidades, $3^{\mathrm{a}}$ ed., Rio de Janeiro, Aide, 1985, p. 55; BuEnO, Cássio Scarpinella, Comentário ao artigo 458, cit. n. 73, p. 1430.

${ }^{165}$ TARUFFO, Michele, La motivazione della sentenza civile, cit. $n$. 1, pp. 149-150.

166 TARUFFo, Michele, La motivazione della sentenza civile, cit. n. 1, pp. 151-152; GOMES FILHO, Antonio Magalhães, A motivação das decisões penais, cit. n. 24, p. 119.

${ }^{167}$ TARUFFO, Michele, La motivazione della sentenza civile, cit. $n$. 1, pp. 152-155.
} 
lógico-dedutivo, mas heurístico, hipotético e avaliativo. Caso seja uma teoria da motivação, também está errada, pois a motivação se utiliza de outros instrumentos lógicos diferentes da dedução e, em alguns momentos (isto é, aqueles nos quais se justifica a valoração axiológica) sequer é possível recorrer a esses instrumentos. ${ }^{168}$

Para que o silogismo possa ser utilizado no raciocínio decisório, é necessário que as proposições que se pretende juntar (premissas) tenham certas características lógicas (e.g., certeza). Essas características, por sua vez, são raras tanto no juízo de fato quanto na determinação da norma aplicável. O momento mais comum em que o raciocínio silogístico é aplicável é exatamente aquele da subsunção ${ }^{169}$ — assim entendido como o momento de conexão entre fato e norma. Em outros momentos do raciocínio decisório é necessário o recurso a outros instrumentos lógicos e também de instrumentos fora da lógica. Deve ser observado que, mesmo estejam presentes as condições necessárias para a utilização do silogismo, esse pode não ser o melhor instrumento para desenvolver determinado ponto do raciocínio. Isso porque o silogismo é um instrumento muito formal e inflexível, de natureza tautológica e sem valor heurístico.

Embora o silogismo possa ser utilizado no contexto do raciocínio justificativo (fundamentação), novamente essa utilização está condicionada a presença de certos pressupostos lógicos. No caso da motivação, o caso mais comum de utilização incorreta do raciocínio silogístico é aquele no qual não existe a relação geral/particular (ou conteúdo/continente) entre as premissas. $\mathrm{O}$ uso indiscriminado do silogismo na motivação resulta em uma justificação da decisão que dá a impressão de ser inescapável, pois resulta de uma concatenação lógica fechada de raciocínios silogísticos.

Essa construção da motivação ignora a complexidade tanto do juízo fático quanto do jurídico e peca pela incompletude, uma vez que seleciona nesses juízos apenas os momentos ou aspectos capazes de atuar como premissa no raciocínio silogístico. ${ }^{170}$ A visão da motivação como um polissilogismo não é capaz de justificar as escolhas e valorações

\footnotetext{
${ }^{168}$ TARUFFO, Michele, La motivazione della sentenza civile, cit. n. 1, pp. 155-156.

${ }^{169}$ LECLERC, Olivier, Le juge et l'expert: contribution à l'étude des rapports entre le droit et la science, Paris, LGDJ, 2005, pp. 78-81; GOMES FILHO, Antonio Magalhães, A motivação das decisões penais, cit. $n$. 24, p. 170.

${ }^{170}$ TARUFFO, Michele, La motivazione della sentenza civile, cit. n. 1, pp. 157-161 e n. 21
} 
que o juiz faz durante a decisão, que vêm apresentadas como consequências lógicas necessárias de outras premissas. ${ }^{171}$

Apesar dos defeitos e incompletudes da estruturação da motivação como polissilogismo, ainda assim o recurso a ela é bastante comum. Isso se deve ao fato de que uma motivação assim estruturada é mais persuasiva, já que sua(s) conclusão(ões) parece(m) inevitável(is) ${ }^{172}$. A teoria do silogismo, seja quando aplicada ao raciocínio decisório, seja quando aplicada à fundamentação, tem uma função ideológica. Nessa perspectiva, reflete a imagem de um ordenamento completo e sistematizado, no qual a norma é um dado preexistente cuja interpretação é meramente cognoscitiva e que essas atividades sejam necessárias e suficientes para a construção da premissa maior.

Supõe, ainda, quanto ao juízo de fato, a existência de um universo governado por leis gerais de natureza causal e no qual o conhecimento indireto dos fatos seja possível com caráter de certeza. Diante desse quadro, a decisão final é consequência necessária da relação entre um fato cuja ocorrência e características são certas e de uma norma em cuja fattispecie o fato se encaixa perfeitamente. O juiz, nessa visão ideológica da teoria do silogismo, é um juiz neutro em relação aos interesses em jogo e passivo, pois sua função é a de declarar a solução ideal da lide, já prevista de maneira abstrata pelo ordenamento. ${ }^{173}$ Assim, a teoria do silogismo limita muito a possibilidade de o juiz realizar escolhas interpretativas — seja na seleção da norma, seja na definição de seu significado —, a atividade criadora do juiz diante das lacunas ou normas em branco, a valoração axiológica e os condicionamentos que influenciam na decisão. ${ }^{174}$

A motivação, segundo essa concepção ideal da teoria do silogismo, coincide com o raciocínio decisório e, por isso, não cumpre — nem tem — a função de justificar a decisão, tornando-a aceitável segundo os critérios de justiça prevalente em uma sociedade histórica e geograficamente localizada, nem de persuadir o público em geral da justiça da decisão. A função da motivação nessa concepção é a de demonstrar a decisão, que era logicamente inevitável e reforçar a autoridade do ordenamento com fundamento em seu caráter lógico e

${ }^{171}$ TARUFFO, Michele, La motivazione della sentenza civile, cit. n. 1, p. 161; GOMES FILHO, Antonio Magalhães, A motivação das decisões penais, cit. n. 24, p. 119.

172 GOMES FILHO, Antonio Magalhães, A motivação das decisões penais, cit. n. 24, p. 119.

${ }^{173}$ TARUFFO, Michele, La motivazione della sentenza civile, cit. $n$. 1, pp. 163-166.

${ }^{174}$ TARUFFO, Michele, La motivazione della sentenza civile, cit. n. 1, pp. 166-167; GOMES FILHO, Antonio Magalhães, A motivação das decisões penais, cit. n. 24, pp. 138-139. 
completo. Por conta de sua estrutura, a motivação, nesse contexto ideológico, só pode ser controlada (controle intraprocessual) do ponto de vista da coerência lógico-formal. ${ }^{175}$

\subsubsection{Críticas ao modelo silogístico}

Uma das críticas ao modelo silogístico sugere a substituição do raciocínio dedutivo pelo raciocínio tópico, ${ }^{176}$ isto é, baseado em topoi, lugares comuns que não compartilham características estruturais entre si e de difícil classificação. A argumentação tópica, por isso, não tem características estruturais definíveis autonomamente que possam indicar qual a função específica dessa argumentação no raciocínio justificativo; nem que permitam a ela assumir uma função central nesse raciocínio.

A ausência de uma estrutura ínsita à argumentação tópica impede, ademais, que ela resolva o problema da estruturação racional da motivação. Isso não significa, no entanto, que a argumentação tópica deva ser inteiramente rejeitada. Ela põe em evidência elementos metalógicos frequentemente utilizados pelos juízes e, explicando-os, permite o controle sobre esse componente da motivação. O raciocínio tópico, portanto, complementa o raciocínio silogístico na formação do discurso justificativo. ${ }^{177}$

Outra crítica importante ao modelo silogístico é feita pela Nouvelle Rhétorique ${ }^{178}$, que sugere que o raciocínio do juiz é, na realidade, retórico-argumentativo. Essa teoria parte do pressuposto que o raciocínio jurídico é diferente daquele lógico-demonstrativo típico das ciências exatas, pois nele se fazem escolhas valorativas por meio de um raciocínio dialético-prático, cujo critério de racionalidade é retórico-argumentativo — isto é, o controle de racionalidade do raciocínio se dá pela capacidade de convencimento de um "auditório universal".

Essa concepção funda-se, no entanto, em dois sofismas. O primeiro deles é a identificação entre lógica e raciocínio dedutivo-demonstrativo. Nesse ponto, não é porque o "raciocínio

\footnotetext{
${ }^{175}$ TARUFFO, Michele, La motivazione della sentenza civile, cit. $n$. . 1, p. 168.

176 VIEHWEG, Theodor, Topik und Jurisprudenz: Ein Beitrag zur rechtswissenschaftlichen Grundlagenforschung, trad. port. de Ferraz Junior, Tércio Sampaio, Tópica e jurisprudência, Distrito Federal Imprensa Nacional, 1979, passim.

177 TARUFFO, Michele, La motivazione della sentenza civile, cit. n. 1, pp. 170-191.

${ }^{178}$ PeRElman, Chaïm e OlBReCHTS-TYTECA Lucie, Traité de l'argumentation: la nouvelle rhétorique, $5^{\mathrm{a}}$ ed., Bruxelles, Editions de l'Université de Bruxelles, 1988, passim.
} 
jurídico" não é exclusivamente dedutivo-demonstrativo que este deixa de ser lógico. O segundo sofisma é extrair de parte do "raciocínio jurídico" toda sua estrutura. Assim, embora escolhas valorativas façam parte do raciocínio decisório, não são seu único componente e não impõem que todo o raciocínio estruture-se segundo o modelo retóricoargumentativo.

A concepção retórico-argumentativa, além disso, considera só existir um "raciocínio jurídico", ignorando as diferenças (estruturais) entre e.g. o raciocínio do juiz e o raciocínio do advogado. Ignora também a distinção entre juízo de valor, que se justifica retoricamente, e juízo de validade, que se justifica logicamente.

Por fim, a teoria retórico-argumentativa é incapaz de fornecer um critério válido de racionalidade do raciocínio, uma vez que a capacidade de convencer o auditório universal é um conceito bastante indefinido. Esse critério é, ademais, ideologicamente conservador, pois sua capacidade de convencimento desse auditório depende do recurso a lugares comuns e preconceitos compartilhados.

A incapacidade do modelo retórico-argumentativo representar todo o raciocínio decisório ou justificativo, no entanto, não significa sua inutilidade. Primeiramente, ela aponta a existência de partes do raciocínio do juiz de valorações axiológicas e de escolhas discricionárias que não podem ser expressadas por meio de uma dedução. Em segundo lugar, ela demonstra a existência de momentos de argumentação persuasiva na motivação, na qual predominam, no entanto, momentos de argumentação lógica (não necessariamente dedutiva). Por fim, ela indica a necessidade de relativizar o conceito de racionalidade no âmbito jurídico, por conta das diferentes funções do discurso jurídico e do discurso das hard sciences. A racionalidade, assim, não implica o recurso exclusivo ao raciocínio dedutivo e é influenciada não só pela função do discurso como também pela premissas filosóficas e ideológicas por trás desse discurso. ${ }^{179}$

${ }^{179}$ TARUFFO, Michele, La motivazione della sentenza civile, cit. $n$. 1, pp. 191-205. 


\subsection{Estrutura racional da sentença}

Diante das críticas ao modelo silogístico e da insuficiência das concepções que pretendem suplantá-lo, contata-se ser praticamente impossível formular um esquema da motivação e do raciocínio decisório que seja estruturalmente homogêneo e unitário e leve em conta todos os momentos desses raciocínios. Toda estrutura homogênea e unitária deixaria de levar em conta, ou diminuiria exageradamente a importância, de alguns dos momentos desse raciocínio. ${ }^{180}$

A impossibilidade de construir teoricamente um modelo estrutural homogêneo e unitário para a motivação não implica a impossibilidade de configuração racional desse raciocínio justificativo. A racionalidade ${ }^{181}$ pode existir quando todos os momentos que compõem o raciocínio tenham uma racionalidade própria e se organizem de maneira coerente com a função justificativa da motivação.

É impossível construir uma estrutura racional da motivação universalmente válida, já que a função da motivação é geográfica e temporalmente localizada. A construção dessa estrutura racional depende da identificação de seus componentes independentes e autônomos, que podem se combinar de diversas maneiras a depender de cada discurso justificativo individual.

A racionalidade e logicidade que se atribuem a cada uma das fases do raciocínio do juiz determinam sua colocação na estrutura global e a natureza específica de cada argumento determina as condições de validade lógica - nem sempre rigorosamente lógica - que permitem sua utilização pelo juiz. A função justificativa da motivação, por outro lado, determina a estrutura interna do raciocínio, bem como o modo de uso de cada um de seus componentes. A estrutura global do raciocínio é determinada, portanto da interação da função do raciocínio considerado em sua inteireza e da função que cada um de seus componentes desenvolve nesse âmbito. ${ }^{182}$

\footnotetext{
${ }^{180}$ TARUFFO, Michele, La motivazione della sentenza civile, cit. n. 1, pp. 207-208.

${ }^{181}$ A racionalidade também existe nas ciências interpretativas, mas é contextual a elas. Da mesma maneira, é possível falar até mesmo no conceito de verdade nas ciências interpretativas. A verdade correponde, nesse conterxto, ao sucesso único em responder uma pergunta, conforme DWORKIN, Ronald, Justice for hedgehogs, cit. $n$. 36, em particular pp. 120-122.

${ }^{182}$ TARUFFO, Michele, La motivazione della sentenza civile, cit. n. 1, pp. 209-211.
} 
O raciocínio justificativo é uma entidade complexa e qualitativamente heterogênea composta por elementos lógicos, quase lógicos, tópicos, valorativos e retóricos ${ }^{183}$. Essa entidade complexa, no entanto, tem um caráter unitário que decorre de sua função justificativa.

O raciocínio justificativo, globalmente considerado, não se estrutura como um sistema cogente de implicações lógicas por conta da heterogeneidade de seus componentes. A estrutura que assume é a de um sistema aberto — pois não é possível definir de antemão seus componentes - de nexos funcionais - que surgem com vistas à função do raciocínio globalmente considerado. ${ }^{184}$

\subsection{Raciocínio do juiz como um conjunto estruturado de escolhas}

A distinção no gênero "raciocínio do juiz" entre raciocínio decisório e raciocínio justificativo reflete uma distinção traçada de maneira ampla pela metodologia lógica e científica entre context of discovery e context of justification. Segundo essa distinção, o primeiro contexto é o procedimento que conduz a formular a solução de um problema, enquanto o segundo é o procedimento de demonstração de validade da solução. Pode haver coincidências ou interferências entre os dois contextos, o que não exclui a distinção entre eles. $^{185}$

No caso específico da motivação, que se insere no context of justification é possível distinguir entre a atividade de seleção e articulação dos motivos aptos a justificar a decisão e o resultado dessa atividade, que exprime a justificação da decisão. É ao segundo que se refere quando se fala na estrutura da motivação ou do raciocínio justificativo. ${ }^{186}$

Um modelo estrutural da motivação não se confunde com um modelo lógico stricto sensu da mesma, uma vez que nem todos os elementos que a compõem são lógicos. O raciocínio

\footnotetext{
${ }^{183}$ GoMES FILHO, Antonio Magalhães, A motivação das decisões penais, cit. n. 24, pp. 122-123.

184 TARUFFO, Michele, La motivazione della sentenza civile, cit. $n$. 1, pp. 212-213.

${ }^{185}$ Idem, pp. 214-215.

186 TARUFFO, Michele, La motivazione della sentenza civile, cit. n. 1, p. 215; GOMES FILHO, Antonio Magalhães, A motivação das decisões penais, cit. n. 24, p. 112.
} 
decisório, bem como a motivação, têm partes lógicas e "não-lógicas". Assim, a estrutura desses raciocínios deve levar em conta todas as partes do discurso e organizá-las. ${ }^{187}$

Para identificar a estrutura da motivação, é necessário antes estudar o raciocínio decisório, pois essa estrutura depende da função da motivação, que é exatamente justificar racionalmente a decisão. Nessa perspectiva, a natureza operativa da decisão judicial é a escolha de uma entre diversas alternativas possíveis.

A identificação da decisão judicial como uma escolha implica a necessidade de formulação das alternativas possíveis e de identificação dos elementos de fato e de direito que fundam cada alternativa ${ }^{188}$. Disso decorre que a decisão final decorre de elementos que também são individuáveis por meio de escolhas.

Essa decisão final é, portanto o resultado de uma concatenação de escolhas, cada uma das quais com suas próprias alternativas e critérios de escolha. Existe um vínculo lógico entre essas diversas escolhas que, no entanto, não altera o caráter aberto do contexto, uma vez que não é possível determinar de antemão o número, natureza e conteúdo das escolhas que serão realizadas. Esse vínculo lógico entre as escolhas, ademais, não implica um sistema dedutivo, mas somente que se respeite a compatibilidade entre as escolhas concatenadas.

O requisito de compatibilidade entre as escolhas é um dos — mas não o único — filtros de racionalidade do discurso. Cada escolha realizada no processo decisório é feita de acordo com critérios e regras de orientação que permitam a identificação da "melhor" alternativa. Esses critérios e regras de orientação, por sua vez determinam a estrutura de cada escolha e são, eles mesmos, frutos de escolhas. Por sua vez, a escolha e aplicação correta dos critérios e regras de orientação — segundo os cânones do próprio critério ou regra —, bem como a correta identificação das alternativas possíveis são o critério de racionalidade de uma escolha específica. Na motivação, as escolhas que o juiz faz para chegar à decisão devem ser reformuladas de modo a serem enxergadas como escolhas racionais e capazes de justificar a decisão final. ${ }^{189}$

\footnotetext{
${ }^{187}$ TARUFFO, Michele, La motivazione della sentenza civile, cit. $n$. . 1, p. 216.

${ }^{188}$ GOMES FILHO, Antonio Magalhães, A motivação das decisões penais, cit. n. 24, p. 122.

189 TARUFFO, Michele, La motivazione della sentenza civile, cit. n. 1, pp. 217-220; GOMES FILHO, Antonio Magalhães, A garantia da motivação das decisões judiciais na Constituição de 1988, cit. n. 21 , p. 69.
} 
De um lado, no âmbito do raciocínio decisório, a racionalidade das escolhas que o juiz faz depende de ter sido racionalmente formulada de acordo com a correção das operações que a constituem. No âmbito do raciocínio justificativo, de outro lado, essa racionalidade decorre da escolha ser apresentada como a melhor consequência da aplicação dos critérios de decisão às premissas. Assim, no âmbito da motivação, a racionalidade não é aquela da própria decisão, mas de sua justificação.

As diferenças entre raciocínio decisório e justificativo não implicam que aquele só possa ser considerado sob a ótica da psicologia ou que seja uma atividade irracional racionalizada pela motivação. Essas diferenças, na realidade, são mais bem explicadas tendo em vista a distinção entre context of discovery e context of justification. Do enquadramento do raciocínio decisório como context of discovery resulta que esse raciocínio pode ser racional e que as escolhas realizadas nesse contexto devem ser entendidas como um modelo lógico, de acordo com os critérios de decisão. ${ }^{190}$

\subsection{Elementos da estrutura da motivação}

A estrutura do raciocínio decisório depende de como se estruturam alguns dos momentos que o compõem, nomeadamente a fixação da norma (item 3.5.1), a determinação dos fatos (item 3.5.2) e a instauração da relação entre fato e norma (item 3.5.3), que conduz à decisão (item 3.5.4). ${ }^{191}$

\subsubsection{Fixação da norma aplicável}

A fixação da norma que deve ser aplicada à fattispecie não significa a mera identificação da norma no ordenamento, mas implica sua escolha entre outras normas que poderiam ser aplicadas. Existem, é verdade, hipóteses nas quais claramente identifica-se a única norma aplicável ao caso e outras, nas quais não há nenhuma norma diretamente aplicável ao caso (lacunas jurídicas). ${ }^{192}$ Essas situações não podem relevadas, mas constituem a minoria dos

\footnotetext{
190 TARUFFO, Michele, La motivazione della sentenza civile, cit. $n$. 1, pp. 221-223.

${ }^{191}$ Idem, p. 223.

192 GOMES FILHO, Antonio Magalhães, A garantia da motivação das decisões judiciais na Constituição de 1988, cit. n. 21 , pp. 70-71.
} 
casos decididos pelos juízes. Por esse motivo, o modelo "padrão" de fixação da norma é aquele no qual o juiz realiza uma escolha. ${ }^{193}$

Quando se fala em fixação "da norma" deve-se entender a fixação do conjunto de normas apto a resolver globalmente as questões da lide, não da fixação individual de cada norma apta a resolver cada questão a ser resolvida. Isso significa que a fixação da norma deve levar em conta os termos da lide, o que cria uma relação dialética entre a fixação da norma é a determinação dos fatos. Nessa perspectiva, o juiz traça um quadro provisório e inicial da situação fática que se lhe apresenta e, diante desse quadro, formula as primeiras possibilidades de norma (rectius, conjunto de normas) capazes de levar à decisão. A interação entre fixação da norma e determinação dos fatos é dialética, de modo que tanto um quanto o outro são objeto de construção gradual com influências recíprocas. ${ }^{194}$

A formulação de hipóteses iniciais das normas que poderiam ser aplicadas no caso pode ser feita com recurso à tópica - já que não se parte de concepção rigorosamente sistemática do raciocínio jurídico - , que funciona para recuperar pontos de vista potencialmente relevantes. Assim, diante das possibilidades de conjuntos de normas aptas a ser aplicadas sobre o thema decidendum, o juiz realiza sua escolha acordo com um critério de escolha. Vale notar que, embora, em abstrato, a escolha seja feita entre todos os possíveis conjuntos de normas, na prática o número de possibilidades é mais limitado. ${ }^{195}$

O procedimento de fixação da norma é, portanto heurístico-hipotético — na formulação das hipóteses de normas potencialmente aplicáveis — e dialético — na construção gradual da norma a ser aplicada em confronto com o thema decidendum. ${ }^{196}$ Os conjuntos de normas potencialmente aptos a compor a decisão funcionam como hipóteses de trabalho do juiz, que determina seu comportamento de acordo com o quadro mais confiável dos termos da controvérsia de que dispõe em dado momento do processo. Assim, por exemplo, o juízo de admissibilidade de provas no momento do despacho saneador leva em conta essa

\footnotetext{
193 TARUFFO, Michele, La motivazione della sentenza civile, cit. $n .1$, p. 224.

194 TARUFFO, Michele, La motivazione della sentenza civile, cit. n. 1, pp. 224-225; GOMES FILHO, Antonio Magalhães, A motivação das decisões penais, cit. $n$. 24, p. 129.

195 TARUFFO, Michele, La motivazione della sentenza civile, cit. $n$. 1, pp. 225-226.

196 TARUFFO, Michele, La motivazione della sentenza civile, cit. $n$. 1, pp. 226-227; LECLERC, Olivier, Le juge et l'expert: contribution à l'étude des rapports entre le droit et la science, cit. n. 169, pp. 152-155; GOMES FILHO, Antonio Magalhães, A motivação das decisões penais, cit. n. 24, pp. 170-171.
} 
hipótese de trabalho, que certamente será distinta da visão que o juiz terá dos termos da controvérsia no momento da sentença.

A construção gradual e dialética - com referência ao thema decidendum — do conjunto de normas a ser aplicadas significa, de um lado, a rejeição das hipóteses que vão se demonstrando inadequadas e, de outro a convalidação de outras. As hipóteses que sobrevivam aos sucessivos testes de adequação serão aquelas entre as quais o juiz, no momento final da decisão, deverá fazer a escolha. Essa escolha final, por sua vez, depende de fatores como juízos de valor ou análises teleológicas. ${ }^{197}$

A fixação do conjunto de normas aplicável passa, ainda, por um momento de interpretação, no qual se determina o critério adequado para a resolução da controvérsia, isto é, a norma aplicável. Nesse sentido, a norma é o resultado da interpretação, não seu objeto ${ }^{198}$. Assim, os processos de seleção e interpretação da norma não são processos distintos, apenas momentos de um mesmo processo. ${ }^{199}$

A interpretação, vale notar, não significa a extração do único sentido possível do texto normativo, mas o conjunto de escolhas interpretativas que o juiz realiza. Mesmo as hipóteses iniciais de trabalho (possíveis normas aplicáveis ao caso, identificadas no primeiro contato que o juiz tem com a controvérsia) são resultado de interpretação mesmo que de interpretações já existentes às quais o juiz recorre por meio da tópica. ${ }^{200}$

O aspecto mais relevante da interpretação — inserida na fixação da norma aplicável — refere-se aos critérios utilizados nas escolhas interpretativas. Esses critérios são heterogêneos e determinam quais os possíveis significados do texto normativo - que se extraem das diferentes perspectivas exegéticas - e qual desses significados deve prevalecer $^{201}$. Existem três gêneros de critérios que determinam quais os possíveis significados do texto normativo: critérios lógico-semânticos, sistemáticos e valorativos.

\footnotetext{
${ }^{197}$ TARUFFO, Michele, La motivazione della sentenza civile, cit. $n$. 1, pp. 227-230.

${ }^{198}$ BuEno, Cássio Scarpinella, Direito, interpretação e norma jurídica: uma aproximação musical do direito in Revista de Processo, v. 28, n. 111, 2003, pp. 226-228; GoMES FILHO, Antonio Magalhães, A motivação das decisões penais, cit. n. 24, p. 135.

${ }^{199}$ GOMES FILHO, Antonio Magalhães, A garantia da motivação das decisões judiciais na Constituição de 1988, cit. n. 21, pp. 70-71.

${ }^{200}$ TARUFFO, Michele, La motivazione della sentenza civile, cit. n. 1, pp. 230-231.

${ }^{201}$ GoMES FILHO, Antonio Magalhães, A motivação das decisões penais, cit. n. 24, pp. 140-141.
} 
Esses mesmos gêneros de critérios são utilizados para a determinação de qual dos possíveis significados do texto normativo deve prevalecer. Nessa segunda perspectiva, o juiz pode escolher, respectivamente a intepretação que tenha maior grau de coerência lógica na relação entre norma e fato; a norma que seja mais coerente com o sistema no qual se insere, ou cuja aplicação produza efeitos mais coerentes com esse sistema; ou ainda a norma mais coerente com os valores que o juiz entenda que devam influenciar a interpretação. $^{202}$

A atividade interpretativa é um procedimento descontínuo, no qual é possível identificar momentos lógicos e valorativos que se condicionam dialeticamente. Nessa perspectiva, o juiz pode, por exemplo — dentre as diversas possibilidades de combinação entre gêneros de critérios —, se utilizar de critérios lógico-semânticos para definir os possíveis significados da norma e de critérios valorativos para decidir qual dos significados deve prevalecer.

O caráter descontínuo e heterogêneo do processo interpretativo revela a inadequação das construções unitárias e estáticas desse processo ${ }^{203}$. Revela também que as escolhas interpretativas são relativas e que não há que se falar em interpretação correta ou verdadeira senão no sentido de que os critérios que guiaram o procedimento interpretativo são válidos ${ }^{204}$ e as escolhas e operações hermenêuticas realizadas pelo juiz sejam racionais em vista desses critérios. ${ }^{205} \mathrm{~A}$ validade dos critérios que guiaram o processo de interpretação depende de sua justificação, de maneira que desse processo emane uma racionalidade intersubjetiva. ${ }^{206}$

\subsubsection{Determinação dos fatos}

O thema probandum é composto pelos fatos juridicamente relevantes cuja ocorrência seja contestada, sobre os quais se formulam hipóteses relativas à sua verdade ou falsidade. A determinação do thema probandum pressupõe uma qualificação jurídica dos fatos que a

\footnotetext{
202 TARUFFO, Michele, La motivazione della sentenza civile, cit. n. 1, pp. 231-236.

${ }^{203}$ GOMES FILHO, Antonio Magalhães, A motivação das decisões penais, cit. n. 24, p. 134.

${ }^{204}$ Válidos no contexto da doutrina jurídica, que cria uma esfera específica de significação, conforme PORSCHER, Ralf, Ambiguity and Vagueness in Legal Interpretation cit. n. 11, p. 32.

${ }^{205}$ TARUFFO, Michele, La motivazione della sentenza civile, cit. $n$. 1, pp. 236-238.

${ }^{206}$ GOMES FILHO, Antonio Magalhães, A garantia da motivação das decisões judiciais na Constituição de 1988, cit. n. 21, pp. 71-72.
} 
compõem. Dessa maneira, como já destacado (supra 3.5.1), a determinação dos fatos e a fixação da norma influenciam-se dialeticamente. ${ }^{207}$

A determinação dos fatos se coloca como a escolha da hipótese mais confiável - aquela com maior grau de confirmação lógica e gnosiológica - com base no que se extrai do conjunto probatório destinado a constituir a "verdade judicial" sobre os fatos. O procedimento de determinação dos fatos é cognoscitivo com o objetivo de estabelecer asserções sobre a ocorrência de fatos e estrutura-se em uma sequência concatenada de inferências factuais.

Essa sequência de inferências tem como objetivo determinar o grau de probabilidade de ocorrência dos fatos com base nos elementos de prova de que dispõe o juiz. $\mathrm{O}$ fato de estruturar-se como uma sequência de inferências significa que sua validade depende da correição lógica das inferências que lhe compõem. ${ }^{208}$

Os critérios observados pelo juiz nas escolhas realizadas na determinação dos fatos são condicionados por fatores de ordem ideológica. A ideologia do legislador, por exemplo, determina os espaços de escolha discricionária do juiz no juízo de fato. Nesse sentido, de um lado, em contextos nos quais o legislador confia menos no juiz, haverá mais regras sobre a inadmissibilidade de determinados meios de prova ou sobre o valor probante de determinados meios de prova. De outro lado, em contextos nos quais o legislador confia na capacidade do juiz de determinar racionalmente os fatos, ao juiz será conferida maior liberdade na apreciação das provas e até a possibilidade de iniciativa probatória.

A ideologia do juiz determina como ele se utiliza da discricionariedade conferida em maior ou menor grau pelo legislador. Assim, um juiz mais autoritário utilizar-se-á de seu livre convencimento para deixar de justificar corretamente suas escolhas na determinação dos fatos, ${ }^{209}$ enquanto um juiz mais democrático tende a reconhecer que a verdade factual, sempre que possível, deve conformar-se às ciências empíricas, de modo a reduzir a

\footnotetext{
207 TARUFFO, Michele, La motivazione della sentenza civile, cit. $n .1$, pp. 239-240.

${ }^{208}$ TARUFFO, Michele, La motivazione della sentenza civile, cit. n. 1, pp. 240-241; 247; GOMES FILHO, Antonio Magalhães, A motivação das decisões penais, cit. n. 24, p. 163.

${ }^{209}$ GOMES FILHO, Antonio Magalhães, A garantia da motivação das decisões judiciais na Constituição de 1988, cit. n. 21, p. 72.
} 
possibilidade de avaliação subjetiva, ao passo que aumenta a possibilidade de controle do raciocínio de determinação dos fatos.

O fato de considerações de ordem ideológica influenciarem a determinação dos fatos (principalmente nos limites da liberdade do juiz para tal) não altera, no entanto, a estrutura do raciocínio desenvolvido na determinação dos fatos. Essa estrutura, como já se viu é a de sequência concatenada de inferências. $O$ fato de o raciocínio tópico ter lugar na determinação dos fatos - e.g. na seleção de máximas de experiência utilizadas para valorar o material probatório - também não é capaz de alterar essa estrutura.

Também quanto à determinação dos fatos (a exemplo do que ocorre na fixação da norma, conforme supra 3.5.1), sua construção é gradual. Nesse caso, conforme se avança na concatenação de inferências, rejeitam-se as hipóteses que vão se demonstrando inadequadas e convalidam-se as outras. ${ }^{210}$

\subsubsection{Qualificação jurídica}

A qualificação jurídica é a síntese do processo dialético entre a norma (resultado da interpretação) e os fatos determinados. Nesse processo, a escolha do significado que se atribui à norma deve levar em conta as consequências da aplicação dessa norma aos fatos que foram determinados ${ }^{211}$ (critério teleológico de interpretação). O recurso a esse critério teleológico de interpretação faz com a estrutura do processo de qualificação jurídica não seja somente lógico-dedutiva, mas também hipotético-deliberativa.

A qualificação jurídica é mais bem entendida como a contraposição entre um critério geral unificante (a norma) e uma situação particular diferenciada (o fato). Assim, uma norma define uma classe de situações-tipo às quais se aplicam efeitos jurídicos enquanto a fattispecie particular é identificada por uma definição da espécie que leva em conta as peculiaridades que a diferenciam de outras situações. ${ }^{212}$

\footnotetext{
${ }^{210}$ TARUFFO, Michele, La motivazione della sentenza civile, cit. n. 1, pp. 244-245, 247-248.

${ }^{211}$ GARCIA, André Almeida, Prova Civil, cit. n. 51, pp. 64-65.

${ }^{212}$ TARUFFO, Michele, La motivazione della sentenza civile, cit. $n$. 1, pp. 248-250, 253-254.
} 
A qualificação jurídica pode envolver um raciocínio criativo do juiz. ${ }^{213}$ Isso acontece nas hipóteses em que o fato determinado não se enquadra no núcleo de significação da norma, mas na "zona de penumbra", na qual ambiguidades e vaguezas da linguagem usada pelo legislador não deixam claro se o fato enquadra-se ou não no âmbito da norma. Nesses casos, ao aplicar ou deixar de aplicar a norma a esse fato na "zona de penumbra" o juiz precisa o significado e o campo de aplicação da norma. ${ }^{214}$

A qualificação jurídica tem, assim, de enfrentar um problema semântico. Esse problema consiste no fato de as asserções fáticas serem formuladas na linguagem comum, ao passo que as asserções jurídicas são formuladas na linguagem científica do direito. A tradução entre as duas linguagens pode seguir um procedimento que se desenvolve segundo regras lógico-semânticas, mas não exclui momentos de valoração. Esse procedimento é constituído de duas operações em sentido contrário. De um lado, "generaliza-se" o enunciado fático - subsumindo-o a noções e categorias mais gerais - e, de outro, "concretiza-se" o enunciado jurídico - explorando situações concretas dentro da fattispecie abstrata. Essas duas operações interagem dialeticamente, provocando adaptações e transformações dos enunciados até atingir o ponto em que ambos sejam expressos na mesma linguagem.

Além do momento lógico-dedutivo — presente na verificação semântica de adequação entre duas asserções - e do momento teleológico - presente na conformação da intepretação da norma conforme os efeitos da sua aplicação —, a qualificação jurídica tem momentos tópicos — recurso a máximas de experiência e esclarecimentos doutrinários no enfrentamento do problema semântico da qualificação jurídica - e axiológicos presente na qualificação dos fatos com vistas à fattispecie abstrata. Por conta da presença de todos esses momentos, a correção do processo de qualificação jurídica depende da correção lógica de cada operação que compõe esse processo. ${ }^{215}$

\footnotetext{
${ }^{213}$ Existem limites à criatividade do juiz nesses casos, delimitados pelo contexto da doutrina jurídica, conforme PORSCHER, Ralf, Ambiguity and Vagueness in Legal Interpretation cit. n. 11, p. 32.

214 TARUFFo, Michele, La motivazione della sentenza civile, cit. n. 1, p. 251; GOMES FILHO, Antonio Magalhães, A motivação das decisões penais, cit. n. 24, p. 171.

${ }^{215}$ TARUFFO, Michele, La motivazione della sentenza civile, cit. $n$. 1, pp. 251-255.
} 


\subsubsection{A escolha final do raciocínio do juiz}

Da fixação da norma, determinação dos fatos e sua qualificação jurídicas resultam as alternativas entre as quais o juiz faz sua escolha final. Essa escolha é determinada por diversos gêneros de critério que, à imagem do que ocorre nas fases anteriores do raciocínio decisório, combinam e interagem uns com os outros.

O juízo no qual culmina o processo decisório é constituído de um contexto de enunciados — resultados de escolhas anteriores - unidos por nexos lógico-jurídicos. Dentre esses enunciados é possível identificar enunciados normativos, que contêm os critérios jurídicos da decisão; enunciados fáticos, que contêm a verdade judicial sobre os fatos da causa; enunciados qualificativos, que contêm a qualificação jurídica dos fatos relevantes; e enunciados prescritivos em sentido estrito, que estabelecem os efeitos da decisão sobre os fatos. Dentre esses enunciados podem estabelecer-se nexos de implicação (provável ou necessária), de correspondência semântica, de compatibilidade lógica ou semântica e de prejudicialidade lógica ou jurídica. Se entendido o juízo não como o resultado o iter decisório, mas como processo de formação da decisão, sua estrutura é mais complexa e abrange momentos heurístico-hipotéticos e dialéticos. ${ }^{216}$

A racionalidade do juízo - assim entendida como o contexto de enunciados que exprimem a escolha final do juiz — não pode ser aferida de maneira unitária e global nem pode ser solucionada de maneira homogênea entre todos os momentos que o compõem. Isso não significa, no entanto, que essa racionalidade não exista. É possível falar em uma racionalidade do juízo em um sentido "operacionalístico", segundo o qual a racionalidade depende da racionalidade do conjunto de operações que compõem o juízo ${ }^{217}$.

É possível, também, falar em uma racionalidade a propósito da estrutura interna do juízo, que decorre da racionalidade dos nexos entre seus componentes. Essa racionalidade depende da ausência de contradição entre os enunciados que compõem o juízo e entre os pressupostos desses enunciados; da presença de alguns nexos de implicação necessários

\footnotetext{
${ }^{216}$ Idem, pp. 255-258.

${ }^{217}$ GOMES FILHO fala na racionalidade da melhor argumentação possível, A motivação das decisões penais, cit. n. 24, p. 127.
} 
entre norma, fato e consequência jurídica; e do respeito a eventuais nexos de prejudicialidade existentes entre as questões resolvidas.

Esses dois critérios de racionalidade podem e devem ser combinados para que se tenha um critério de racionalidade do juízo ${ }^{218}$ — embora esse critério não forneça uma definição exauriente dessa racionalidade. É possível, ainda, valorar a decisão de acordo com seu conteúdo. Essa valoração, no entanto, não é um juízo de racionalidade, mas uma apreciação valorativa e ideológica.

A racionalidade das operações que compõem o juízo, sob o ponto de vista formal depende da correta aplicação de um critério de escolha dado a alternativas dadas. A racionalidade da seleção dessas alternativas e da definição do critério de escolha, no entanto, depende de outros cânones, heterogêneos entre si e que podem cruzar-se e sobrepor-se uns aos outros.

Um desses cânones é o conjunto de regras lógicas e suas condições de aplicação. Outro é a "lógica" típica dos juristas, composta por argumentos "quase-lógicos", pelo método tópico de formulação de problemas e de recuperação de materiais para resolvê-los. Essa lógica tem uma eficácia heurística na identificação das alternativas possíveis e na definição dos critérios de escolha ${ }^{219}$. Na ótica desse cânone, o raciocínio é racional se tiver considerado adequadamente todos os aspectos e escolhas relevantes da controvérsia.

O terceiro cânone de racionalidade diz respeito aos juízos de valor feitos no raciocínio decisório. Esses juízos de valor podem ter sua racionalidade derivada dos outros dois cânones já apontados, mas também de sua correta inserção em um determinado sistema de valores. ${ }^{220}$ A avaliação de racionalidade de um juízo de valor de acordo com sua coerência com um determinado sistema de valores significa que essa racionalidade é ideologicamente relativa e condicionada. ${ }^{221}$

\footnotetext{
${ }^{218}$ GOMES FILHO, Antonio Magalhães, A garantia da motivação das decisões judiciais na Constituição de 1988, cit. n. 21 , pp. 77-78.

${ }^{219}$ GOMES FILHO, Antonio Magalhães, A motivação das decisões penais, cit. n. 24, pp. 123-124.

${ }^{220}$ A justificação do juízo de valor dentro do sistema de valores segue a mesma forma que a justificação da colisão de princípios na teoria de ALEXY, uma vez que valores e princípios etêm a mesma estrutura. ALEXY, Robert, Theorie der grundrecht, cit. n. 114, pp. 144, 147-151.

${ }^{221}$ TARUFFO, Michele, La motivazione della sentenza civile, cit. $n$. 1, pp. 258-264.
} 


\subsection{Estrutura da motivação conforme sua função justificativa}

A motivação, vale lembrar, é a justificação do resultado do raciocínio decisório (decisão). O fato de a decisão derivar de um procedimento heurístico, deliberativo, complexo, descontínuo e não condicionado logicamente não significa a impossibilidade de a motivação justificar racionalmente a decisão, até porque a motivação não se confunde com o raciocínio decisório nem, tampouco, deve refletí-lo fielmente.

A descontinuidade e heterogeneidade do raciocínio decisório, no entanto fazem com que a motivação não tenha uma estrutura unitária ou homogênea. Assim, a motivação estruturase em módulos diversos, adequados às diferentes necessidades justificativas. A estrutura da motivação depende do que deve ser justificado (item 3.6.1) — isto é dos enunciados que constituem a decisão - e a racionalidade da motivação (item 3.6.2) depende de sua função no discurso do juiz e de sua estrutura. ${ }^{222}$ A manifestação concreta da motivação (item 3.6.3), por sua vez, depende da visão ideológica que se tem dela.

\subsubsection{Os níveis de motivação}

Os nexos lógicos entre as asserções de fato e de direito que compõem o raciocínio decisório determinam parte da estrutura lógica da motivação, mas não exaurem essa estrutura, uma vez que a motivação abrange ainda a justificação das escolhas que resultam nos componentes do juízo final do raciocínio decisório. A estrutura do raciocínio decisório, assim, pode ser representada pelo seguinte esquema:

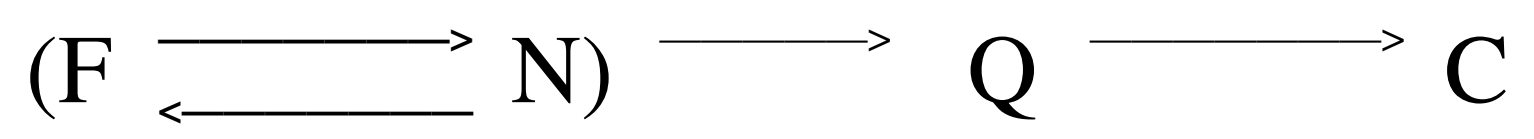

Nesse esquema o fato $(\mathrm{F})$ e a norma $(\mathrm{N})$ estabelecem uma relação de construção dialética entre si. Quando ocorre a coincidência semântica entre os fatos determinados e a norma aplicável, dá-se a qualificação jurídica (Q). Por fim, a qualificação jurídica da fattispecie concreta implica os efeitos da norma e, portanto, a conclusão (C), entendida como o a declaração dos efeitos da norma na relação trazida à lide. É importante chamar atenção para o fato de que esse esquema não se reduz aos módulos da lógica dedutiva. Na

${ }^{222}$ Idem, pp. 265-268. 
realidade, o único momento sempre dedutivo do esquema é a passagem de $\mathrm{Q}$ para $\mathrm{C}$ e mesmo esse momento não é exclusivamente dedutivo, já que implica valorações axiológicas (supra 3.5.4).

Caso a sentença tenha vários capítulos, cada um desses capítulos pode ser representado de acordo com o esquema acima e, nesse caso, para que a motivação seja capaz de justificar racionalmente a decisão é necessário que não haja contradição entre os elementos presentes em cada um dos esquemas. Na hipótese de a sentença ser composta por questões entre as quais exista um nexo de prejudicialidade lógica, a estrutura da decisão (e da motivação) deve ser imaginada como dois esquemas iguais aosapresentado acima em que haja, além de todos os nexos dentro do esquema, um nexo de implicação entre os esquemas.

O sistema de relações lógicas entre os enunciados que exprimem a escolha final do juiz não explica toda a estrutura da motivação. Isso porque cada um desses enunciados é o resultado de escolhas complexas cuja formulação constitui o ponto mais problemático do raciocínio decisório. Nessa visão, a validade de cada um desses enunciados depende da racionalidade das escolhas que a eles levaram. Isso significa que a motivação deve abranger também a justificação dos enunciados F, N, Q e C sob a ótica de seus pressupostos de racionalidade. A estrutura da motivação, portanto, ganha mais um nível e passa a estruturar-se da seguinte maneira:

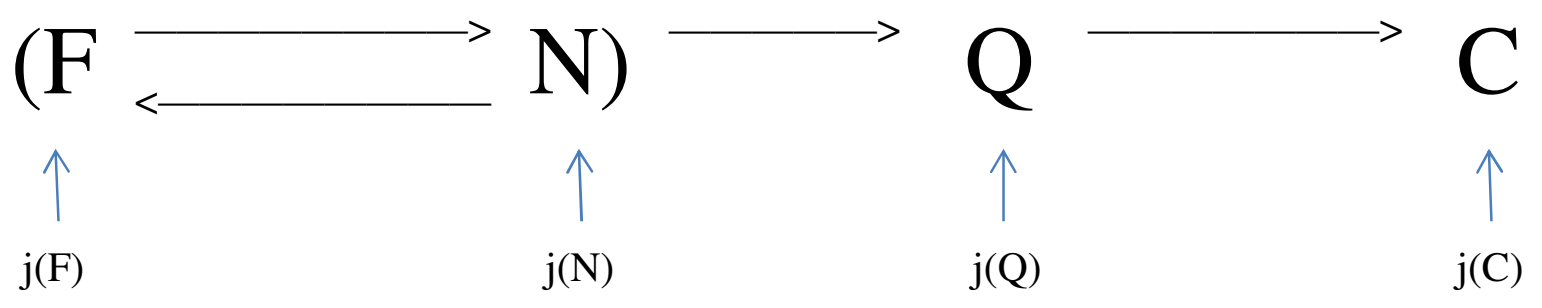

Nesse esquema, $j(F), j(N), j(Q), j(C)$ representam, respectivamente, a justificação da determinação dos fatos, a justificação da fixação da norma, a justificação da qualificação jurídica e a justificação da conclusão do raciocínio. ${ }^{223}$

A justificação de primeiro grau (correspondente ao primeiro nível do esquema) apresenta como "melhor" a escolha entre alternativas dadas, de acordo com um critério de escolha

${ }^{223}$ Idem, pp. 268-276. 
dado. A justificação de segundo grau, por sua vez, diz respeito à escolha dos próprios critérios de escolha.

A justificação de primeiro grau pode ser remetida a um modelo lógico inferencial. É, assim, a conclusão de uma inferência que parte de certas premissas (as alternativas de escolha) segundo critérios de inferência (a regra de escolha). A justificação de segundo grau, no entanto não pode ser remetida a uma inferência. ${ }^{224}$

A justificação da escolha de uma determinada máxima de experiência na determinação dos fatos, por exemplo, dificilmente é justificável no plano lógico. A justificação da adoção de uma máxima de experiência tem caráter tópico, cujo fundamento de racionalidade é a existência de um consenso difuso sobre a utilidade da máxima.

Caso quase oposto de justificação dos critérios de escolha (justificação de segundo grau) é encontrado também no campo da (justificação da) determinação dos fatos. Trata-se da justificação do critério científico utilizado na avaliação de uma fonte de prova, que se dá com referência aos critérios de validade e racionalidade da ciência em questão.

A justificação da fixação - que compreende tanto a seleção do texto normativo quanto sua interpretação — da norma aplicável ao caso passa por dois momentos. No primeiro momento, justifica-se "legalmente" a norma — segundo cânones lógico-jurídicos —, isto é, demonstra-se sua validade por ter sido editada de acordo com o estabelecido por uma norma hierarquicamente superior, no modelo kelseniano. No segundo momento, justificase "extralegalmente" — segundo cânones axiológico-valorativos — a norma, mostrando sua adequação à promoção de determinados valores (e.g. utilidade, justiça). A racionalidade desse segundo momento justificativo depende da identificação daquele que controla a motivação — ou do ambiente social — com os valores eleitos para justificar a escolha $^{225}$ e da norma de fato ser apta a promover esses valores sob o ponto de vista lógico. $^{226}$

\footnotetext{
${ }^{224}$ GOMES FILHO, Antonio Magalhães, A motivação das decisões penais, cit. n. 24, pp. 125-126;

${ }^{225}$ É possível imaginar a justificação da escolha teleológica segundo o método heurístico do véu da ignorância, segundo o qual decisão política correta é aquela tomada da posição original. Isso significa que aquele que toma a decisão não sabe nada sobre as suas características nem sobre as características das demais pessoas que compõem a sociedade, conforme RAWLS, John, A Theory of Justice, Cambridge, Harvard University, 1999, passim.

${ }^{226}$ TARUFFO, Michele, La motivazione della sentenza civile, cit. n. 1, pp. 277-282.
} 


\subsubsection{Racionalidade da justificação}

O conceito de logicidade da motivação deve ser entendido de modo a abranger não só a lógica dedutiva, mas também as lógicas indutiva, inferencial e deôntica. Ademais, a racionalidade da motivação não se confunde com a logicidade da mesma. Nesse sentido, é possível que a motivação seja racional mesmo nos momentos em que não seja lógica, como nos momentos em que são realizados juízos de valor.

Nesses casos, o conceito de racionalidade se desdobra em um momento formal e outro material. Assim, sob o aspecto formal, um discurso é racional quando presentes requisitos de coerência e de ordem lógica e, sob o aspecto material, a racionalidade depende da aceitação das escolhas valorativas pelo destinatário da motivação. Os dois momentos de racionalidade da justificação são heterogêneos, mas coordenáveis.

Nessa perspectiva, o núcleo da justificação é composto pelos momentos que se modelam logicamente e podem ser controlados sob a ótica da correção lógica. Além desse núcleo existe uma área do discurso - que se pode chamar de "quase-lógica" — na qual estão presentes os cânones hermenêuticos da teoria da argumentação jurídica e os argumentos segundo a lógica do razoável — assim, entendida como a lógica do raciocínio prático. A racionalidade desse momento do discurso justificativo depende do respeito ao modo correto de utilização de cada um desses argumentos; da justificação argumentativa possível logicamente; e do fato de essa argumentação não ser viciada sob o ponto de vista da Lógica.

Por fim, existe uma área do discurso justificativo que não se estrutura de maneira lógica nem "quase-lógica" e é composta tão-somente pela argumentação retórico-persuasiva. Quanto a esse momento da motivação, sequer pode se avaliar sua validade, pois está subordinado somente a uma finalidade externa ao discurso justificativo, nomeadamente a de obter o assentimento dos destinatários da motivação. Assim, esse momento é avaliado quanto à sua eficácia, não quanto à sua validade. A racionalidade desse momento discursivo só é controlável quanto ao conteúdo, isto é, quanto às escolhas capazes de provocar o assentimento. 
Ao traçar esse modelo estrutural do discurso justificativo, é necessário lembrar que dele decorre a racionalidade do mesmo. Essa racionalidade, portanto, independe de valores como a justiça do discurso justificativo. Quanto aos três momentos da estrutura do discurso justificativo, vale apontar que não são estanques. Isso significa que, na elaboração da justificação de uma questão pontual da decisão, é possível que dois desses momentos ou mesmo os três estejam presentes e interajam entre si. Essa construção tripartida da estrutura da motivação tem como vantagem evitar a incompletude de qualquer construção unitária e homogênea dessa estrutura. ${ }^{227}$

Para que a motivação globalmente considerada possa ser considerada racional é necessário que cada um dos elementos que compõem sua estrutura tripartida seja racional. Partindo não da estrutura tripartida - que, no entanto, continua relevante para a explicação —, mas dos níveis da motivação, verifica-se que a motivação do primeiro grau do raciocínio decisório (primeiro nível no esquema de fls. 65), assume a forma inferencial. Assim, o enunciado (conclusão do raciocínio) é justificado como o resultado da aplicação dos critérios de inferência às premissas.

Para que essa justificação com base em uma inferência possa ser reputada adequada, é necessário que tanto as premissas da inferência sejam explicitadas como também a passagem lógica que, partindo dessas premissas, chegue à conclusão (enunciado a justificar) seja explicitada. O fato de o raciocínio decisório de primeiro grau corresponder, na esfera da decisão, a uma escolha, não exige que a motivação deva justificar a exclusão das demais alternativas, mas somente que se demonstre a alternativa escolhida como resultado da inferência.

A justificação do raciocínio decisório de primeiro grau pode assumir diferentes formas de inferência (e.g. dedutiva ou indutiva) a depender da natureza lógica do critério justificativo (e.g. havendo um critério hermenêutico geral é possível justificar dedutivamente uma interpretação normativa). Quanto ao raciocínio indutivo, o grau de confirmação lógica e, portanto, a aptidão à justificação — depende da quantidade e da qualidade dos elementos que fundam a indução.

${ }^{227}$ Idem, pp. 283-289. 
A justificação do raciocínio decisório de segundo grau, no entanto, não é passível de ser inteiramente representada por uma estrutura inferencial, o que não significa, vale notar, que esse discurso não possa se estruturar, mesmo que parcialmente, de maneira lógica ou "quase-lógica". Assim, por exemplo, a justificação de segundo grau da intepretação normativa — isto é, a justificação da escolha do critério de interpretação — pode se utilizar de três tipos de argumentos — que podem ser utilizados de maneira conjunta.

O primeiro deles é o argumento tópico-jurídico, que, simplificadamente, funda a racionalidade da escolha de um critério interpretativo na sua utilização pela doutrina ou jurisprudência. $\mathrm{O}$ controle de racionalidade desse argumento diz respeito à existência desses elementos tópicos e em sua aptidão a justificar a escolha.

O segundo tipo de argumento é o teleológico e justifica a escolha do critério interpretativo nas consequências da aplicação do critério. Esse argumento apresenta um nível lógico na medida em que deve demonstrar que o efeito desejado deriva, de fato, da escolha do critério interpretativo em questão. Apresenta, também, um nível valorativo, na medida em que deve justificar a conveniência, justiça, etc. da consequência da aplicação da norma.

O terceiro tipo de argumento é valorativo e tem lugar sempre que o cânone seja constituído de juízos de valor ou se seu significado puder ser determinado com base em juízos de valor. Nesses casos, a justificação resulta do cruzamento entre um discurso estruturado logicamente e de um discurso retórico-persuasivo.

O discurso lógico diz respeito à correspondência (inferencial) entre o valor eleito e o resultado da valoração, ao passo que o discurso retórico argumentativo - que não é controlável logicamente - diz respeito à justificação do valor que assume a função de critério de escolha. Mesmo a justificação do valor que assume a função de critério de escolha no juízo de valor pode, eventualmente, ter uma estrutura parcialmente racional.

Nesse sentido, toda vez que um valor se inserir em um sistema mais amplo de valores, é possível justificar racionalmente a escolha desse valor com referência ao sistema de valores, que convalida a escolha. É a justificação da escolha do sistema de valores ou do próprio valor individual, quando este não se inserir em nenhum sistema de valores, que é sempre retórico-argumentativa. 
Essa justificação tenta buscar o assentimento do destinatário da motivação com base na retórica argumentativa. Assim, embora não se possa dizer que todo discurso justificativo (motivação) seja lógico, fica claro que existem momentos e estruturas lógicas nesse discurso. Ademais, para que seja possível dizer que a motivação é capaz de cumprir sua função de justificar racionalmente a decisão, é necessário entender a racionalidade como o emprego correto dos diversos argumentos justificativos possíveis. ${ }^{228}$

\subsubsection{Estilo da motivação}

O esquema estrutural do discurso justificativo (motivação) que se traçou não descreve como a motivação ocorre na prática, por conta de fatores externos a essa estrutura, que condicionam o estilo da motivação. Esses fatores externos e, consequentemente, os estilos de motivação diferem-se de acordo com as tradições jurídicas e culturais, com o grau e função do órgão judicial e com características pessoais do próprio juiz. A acepção de estilo da motivação cujo estudo é mais interessante diz respeito ao modo particular como se dispõem os elementos estruturais do discurso justificativo.

Nessa acepção, o estilo da motivação depende não só dos fatores externos descritos como também, e principalmente, da ideologia da motivação - que depende da ideologia do juízo e da justiça - em uma sociedade geográfica e temporalmente localizada. A ideologia da motivação influencia seu estilo de maneira que as escolhas discricionárias realizadas pelo juiz sejam mais ou menos explícitas; os juízos de valor - e a escolha dos critérios desses juízos - sejam mais ou menos explícitas; a justificação se limite ao seu aspecto jurídico-formal ou abranja questões axiológico-valorativas; a estrutura da motivação seja mais aberta ou mais fechada; a motivação seja mais lógica ou retórica.

Quanto à justificação dos juízos de valor, o determinante ideológico do estilo da motivação fica ainda mais claro. Nessa perspectiva, a ausência de justificação desses juízos resulta de uma concepção mecânica do direito e mesmo quando esses são justificados, o modo como se justifica a escolha do valor que foi utilizado como critério de escolha no juízo é sintomático quanto às ideologias da sociedade.

${ }^{228}$ Idem, pp. 289-297. 
À ideologia do Estado Democrático de Direito corresponde um estilo de motivação que, reconhecendo a impossibilidade de racionalidade absoluta da decisão judicial, propugna pela máxima racionalidade da mesma. Quanto à motivação, essa ideologia entende que deve ser completa, no sentido de que todos os elementos que racionalizem a decisão devem ser expressos e justificados. ${ }^{229} \mathrm{O}$ ponto mais crítico dessa exigência diz respeito à necessidade de justificar as escolhas de valor das quais depende a decisão.

A estruturação e o conteúdo concretos da motivação dependem, ainda, de quem o juiz vê como destinatário da decisão. Sob essa ótica, e.g. uma motivação destinada à doutrina será mais focada na interpretação conceitual das leis e uma motivação destinada ao público em geral será mais focada na justificação dos juízos de valor.

Além da possibilidade de a motivação concreta exprimir menos do que exigido pelo modelo (infra 3.7.1), existem casos em que ela exprime mais do que é exigido. Isso ocorre nos casos em que exista pluralidade de rationes decidendi e na presença de obiter dicta assim entendidos como os elementos que não fazem parte de uma argumentação justificativa específica nem têm função justificativa autônoma.

A pluralidade de rationes decidendi pode ocorrer quando nenhuma delas é apta a, por si só, justificar racionalmente a decisão, embora, ao mesmo tempo, nenhuma delas possa ser considerada obiter dicta. Essa pluralidade pode ocorrer também quando exista a necessidade de responder às diferentes linhas argumentativas adotadas pelas partes e, por fim, quando é necessário justificar a decisão com referência a mais de uma norma (e.g. motivação legal e constitucional da decisão). De qualquer maneira, sempre que exista uma ratio decidendi apta a justificar racionalmente a decisão, tudo que se lhe acresce inclusive os obiter dicta — tem função persuasiva.

A função persuasiva desses elementos que se acrescentam a ratio decidendi apta a justificar racionalmente a decisão pode ser importante - e é por isso que o fenômeno é comum na prática - para convencer o público e o resto do Poder Judiciário de uma

${ }^{229}$ GOMES FILHO, Antonio Magalhães, A garantia da motivação das decisões judiciais na Constituição de 1988, cit. n. 21 , p. 76 
decisão que rompa com uma orientação jurisprudencial consolidada ou que, a primeira vista, não esteja em consonância com os "valores sociais". 230

Existe um caso, no entanto, em que o excesso de motivação perde sua conotação persuasiva e é possível se falar em "excesso de motivação". Trata-se do caso em que o juiz penal, na sentença de pronúncia, recorre a diversos expedientes retóricos capazes de influenciar a decisão do júri. Nesse caso, a violação ao modelo acusatório implica o vício da motivação excessiva ${ }^{231}$.

\subsection{Os limites da motivação}

A definição do que se exige, em caso concreto, para que se possa considerar que a decisão foi adequadamente motivada, depende de três limites. O primeiro desses limites decorre da estrutura funcional da motivação que se traçou no item 3.6 e será analisado no item 3.7.1. O segundo desses limites decorre da relação entre motivação e contraditório e será mais bem explicado no item 3.7.2. Por fim, a motivação, sendo um discurso, encontra limites na própria linguagem, como se verá no item 3.7.3. Da interação desses limites nasce o modelo — que será apresentado no item 3.7.4 - que servirá de parâmetro para definir se a decisão foi motivada no caso concreto.

\subsubsection{Conteúdo mínimo da motivação}

A partir da função que a motivação tem — fundamentação racional da decisão — é possível determinar seu conteúdo mínimo. Esse limite mínimo da motivação corresponde à justificação adequada de cada um dos elementos do raciocínio decisório. ${ }^{232}$ Corresponde, portanto, à justificação adequada da interpretação da norma, da determinação dos fatos, da qualificação jurídica e da declaração das consequências jurídicas que derivam da decisão. Essa justificação adequada abrange a enunciação — mas não a justificação — dos critérios

\footnotetext{
${ }^{230}$ TARUFFO, Michele, La motivazione della sentenza civile, cit. $n$. 1, pp. 298-317.

${ }^{231}$ BADARÓ, Gustavo Henrique Righi Ivahy, Direito ao julgamento por juiz imparcial: como assegurar a imparcialidade objetiva do juiz nos sistemas em que não há juiz de garantias in Processo penal, Constituição e crítica, BonATO, Gilson (org.), Lumen Juris, Rio de Janeiro, 2011, p. 358; GomeS FILHO, Antonio Magalhães, Excesso de motivação da pronúncia e modelo acusatório in Revista Brasileira de Ciências Criminais, v. 5, n. 19, 1997, pp. 306-310.

${ }^{232}$ FRANCO, Fernão Borba, Aproximação entre processo judicial e administrativo: um enfoque sobre o procedimento e a motivação, cit. $n .51$, p. 186.
} 
que funcionam como premissas das escolhas que o juiz faz em cada um desses momentos. $^{233}$

O conteúdo mínimo da motivação corresponde, portanto, ao primeiro nível da estrutura da motivação (modelo de fl. 65). Para que se possa dizer que foi atingido o conteúdo mínimo, é necessária a justitificação racional de todos os elementos presentes no primeiro grau e dos nexos entre esses elementos, ${ }^{234}$ além da identificação dos critérios presentes no segundo nível da estrutura. Só a partir da justificação de todos os elementos é possível controlar o fundamento racional da decisão. ${ }^{235}$

\subsubsection{Conteúdo da motivação definido pelo contraditório}

Os limites da motivação da decisão judicial são também determinados pelo contraditório. ${ }^{236}$ Isso significa que as partes determinam as alegações fáticas e jurídicas que o juiz tem, necessariamente, de levar em conta para que sua decisão possa ser considerada suficientemente motivada.

As alegações fáticas e jurídicas que devem necessariamente ser levados em conta pelo juiz, sob pena de insuficiência da motivação, são determinados pelo contraditório. ${ }^{237}$ A visão do contraditório como direito de influência, determina que o juiz deve se manifestar sobre todas as alegações das partes, ${ }^{238}$ mesmo que seja somente para dizer que são absurdas ou irrelevantes. $^{239}$

O abuso do direito ao contraditório não pode ser sancionado com a diminuição do dever de fundamentação, até porque o juiz já dispõe de mecanismos aptos a sancionar esse abuso.

\footnotetext{
${ }^{233}$ TARUFFO, Michele, La motivazione della sentenza civile, cit. n. 1, pp. 450-453; GOMES FILHO, Antonio Magalhães, A motivação das decisões penais, cit. n. 24, p. 175.

${ }^{234}$ BADARÓ, Gustavo Henrique Righi Ivahy, Vícios de motivação da sentença penal: ausência de motivação, motivação contraditória, motivação implícita e motivação per relationem, cit. n. 21, p. 127; GOMES FILHO, Antonio Magalhães, A motivação das decisões penais, cit. n. 24, pp. 179-181.

${ }^{235}$ TARUFFO, Michele, La motivazione della sentenza civile, cit. $n$. 1, pp. 462-469.

${ }^{236}$ GOMES FILHO, Antonio Magalhães, A garantia da motivação das decisões judiciais na Constituição de 1988, cit. n. 21, pp. 67-69.

${ }^{237}$ GOMES FILHO, Antonio Magalhães, A motivação das decisões penais, cit. n. 24, p. 177.

${ }^{238}$ BotelHo DE MESQuistA, José Ignacio, Autoridade da coisa julgada e a imutabilidade da motivação da sentença, cit. n.2, p. 44, n. 2; MAHMOUd, Mohamad Ale Hasan e MouRA, Maria Thereza Rocha de Assis, Motivação da sentença condenatória e o habeas corpus perante o Superior Tribunal de Justiça cit. n. 85, p. 218.

${ }^{239}$ BuEno, Cássio Scarpinella, Curso sistematizado de direito processual civil, v. 1, cit. n. 51, p. 135; Comentário ao artigo 458, cit. n. 73, p. 1430.
} 
Na esfera civil, pode impor a multa por litigância de má-fé prevista no artigo 17 do Código de Processo Civil. Na esfera penal, embora não exista previsão de multa por litigância de má-fé, isso não significa que esta não possa ser sancionada. O Superior Tribunal de Justiça vêm decidindo ${ }^{240}$ que a interposição de recurso com caráter protelatório é capaz de afastar a necessidade de aguardar o trânsito em julgado para que se inicie o cumprimento da pena. Por fim, em ambas as esferas, a violação ao dever de boa-fé na esfera profissional pode dar origem à nulificação do ato ${ }^{241}$.

O juiz deve motivar sua decisão levando em conta todas as alegações das partes exatamente porque vivemos em um Estado Democrático de Direito, no qual o exercício da atividade estatal só se legitima por meio da participação que, no Poder Judiciário, se dá por meio do contraditório ${ }^{242}$ (para uma análise mais minuciosa da relação entre contraditório, motivação e Estado Democrático de Direito, supra itens 2.3.2.3, 2.3.2.4 e 2.3.2.5.).

Especificamente quanto à motivação "jurídica" da decisão, é necessário chamar atenção a um ponto. Ao mesmo tempo em que é função das partes trazer ao juiz os fatos relevantes à causa, pressupõe-se que o juiz conheça do direito aplicável. Trata-se, aqui, do "iura novit curia", expressão que pode ser traduzida por "o juiz conhece o direito". Assim, exatamente porque é o juiz, e não as partes, quem conhece o direito, seria possível, com fundamento exclusivamente no "iura novit curia", que o juiz decidisse, e motivasse sua decisão, com base em norma não alegada pelas partes. ${ }^{243}$

O postulado do "iura novit curia", no entanto, deve ser reiterpretado de acordo com a concepção do contraditório como direito de influência. Nesse sentido, o dever de motivação encarado como instrumento de garantia do contraditório impõe ao juiz que dê oportunidade às partes de debater todos os pontos que esse considere relevantes para a

\footnotetext{
$2405^{\text {a }}$ Turma, AgRg nos EDcl no AgRg no AREsp n. 222493, Rel. Min. JoRgE Mussi, j. 20.6.2013, DJe 1.8.2013; $5^{\mathrm{a}}$ Turma, AgRg nos EDcl nos EDcl no AgRg no Ag n. 1020286, Rel. Min. CAMPOS MARQUES

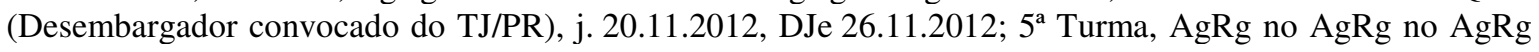
no Ag n. 1425288, Rel. Min. MARCo AurÉLIO BellizZE, j. 25.9.2012, DJe 2.10.2012.

${ }^{241}$ CABRAl, Antonio do Passo, Nulidades no processo moderno: contraditório, proteção da confiança e validade prima facie dos atos processuais, cit. n. 70, pp. 234-235.

${ }^{242}$ GRECO, Leonardo, Garantias fundamentais do processo: o processo justo, cit. n. 69, p. 32.

${ }^{243}$ CorrêA, Orlando de Assis, Sentença cível: elaboração e nulidades, cit. n. 164, p. 56; TUCCI, José Rogério Cruz e, A motivação da sentença no processo civil, cit. n. 3, pp. 104-106; BuENO, Cássio Scarpinella, Comentário ao artigo 458, cit. n. 73, pp. 1430-1431.
} 
(justificação da) decisão. ${ }^{244}$ Inclui-se aí, como é óbvio, a fixação da norma aplicável, motivo pelo qual, embora o juiz não esteja vinculado às normas que as partes aleguem ser relevantes ao deslinde da lide, também não pode surpreendê-las com a aplicação de norma não discutida no processo.

\subsubsection{Motivação e os limites da linguagem}

TARUFFO entende que a necessidade de a motivação ser um discurso finito limita as possibilidades de jusitificação. Assim, haveria um limite aos níveis de justificação, que seria determinado pela suficiência da motivação no desempenho de sua função justificativa. $^{245}$

Essa afirmação, entretanto, decorre de um entendimento incorreto da motivação como discurso. Como já foi dito (supra 2.3.3.2), a ideia de que existem níveis infinitos de fundamentação, na verdade, contraria uma das premissas básicas da linguagem, segundo WiTTGENSTEIN, cuja citação se faz mais uma vez necessária:

“6.5 Se uma resposta não pode ser posta em palavras, também não pode a pergunta. $\mathrm{O}$ enigma não existe. Se se pode de todo fazer uma pergunta então também se pode respondê-la.

6.5.1 O ceticismo não é irrefutável, mas obviamente falho de sentido por pretender por em dúvida o que não pode ser perguntado. E isto porque só pode haver dúvida onde pode haver pergunta, e uma pergunta só onde pode haver uma resposta, e esta só onde algo pode ser dito". 246

Assim, se a motivação é um discurso (item 2.1.1.1) deve obedercer às regras da linguagem, que determinam que, em certo nível de abstração, o que se entende por "pergunta" deixa de sê-lo, isto é, deixa de fazer sentido como pergunta. Assim, não existe o problema do regresso ao infinito, o que permite considerar a motivação como um discurso finito.

\footnotetext{
${ }^{244}$ TARUFFO, Michele, La motivazione della sentenza civile, cit. n. 1, pp. 404-405; TUCCI, José Rogério Cruz e, Garantias constitucionais da publicidade dos atos processuais e da motivação das decisões no Projeto de CPC, cit n. 60, p. 121; GoMES FILHO, Antonio Magalhães, A motivação das decisões penais, cit. $n$. 24, p. 100.

${ }_{245}^{24}$ TARUFFO, Michele, La motivazione della sentenza civile, cit. $n$. 1, pp. 308-310.

${ }^{246}$ Tractatus logico-philosophicus, cit. n. 141, p. 141.
} 


\subsubsection{Critério interativo de suficiência da motivação}

A motivação tem, portanto, três limites. O primeiro limite é o limite mínimo delimitado por sua função de justificação da decisão judicial. Esse limite é abstratamente flexível, mas concretamente rígido. Abstratamente flexível porque os elementos da decisão, que devem ser justificados, podem variar em complexidade de caso a caso, mas concretamente rígida porque, uma vez determinados os elementos do raciocínio decisório, é possível determinar precisamente esses limites da motivação.

O segundo limite é definido pelo contraditório e é abstrata e concretamente flexível. Abstratamente flexível porque não é possível determinar de antemão o objeto do contraditório e concretamente abstrato porque pode ser alterado a qualquer momento e é aparentemente ilimitado - ou seja, as partes, no contraditório, podem debater o que quiserem e, assim, condicionar, aparentemente sem limites o conteúdo da motivação.

O terceiro limite é o limite máximo definido pela linguagem e é abstrata e concretamente rígido. Abstratamente rígido porque a linguagem é um conjunto determinável de antemão, o que possibilita que seus limites - que a própria linguagem impõe - também sejam delimitados de antemão.

O limite mais importante para a aferição da suficiência da motivação no caso concreto é o limite imposto pelo contraditório. Essa aferição, no entanto, depende também da verificação da interação do limite imposto pelo contraditório com o limite mínimo imposto pela função justificativa da motivação e com o limite máximo imposto pela linguagem.

Assim, toda vez que o contraditório não chegar a abranger algum dos elementos do primeiro grau de justificação, os nexos entre eles ou a identificação dos critérios de escolha, o limite mínimo de motivação supera a delimitação do contraditório e impõe que o juiz fundamente a decisão sobre um ponto não debatido pelas partes. Sob outra perspectiva, toda vez que o contraditório superar os limites da linguagem, atingindo níveis de abstração nos quais a pergunta deixa de fazer sentido, o limite máximo reduz a delimitação do contraditório.

A interação entre os limites é mais bem visualizada graficamente: 


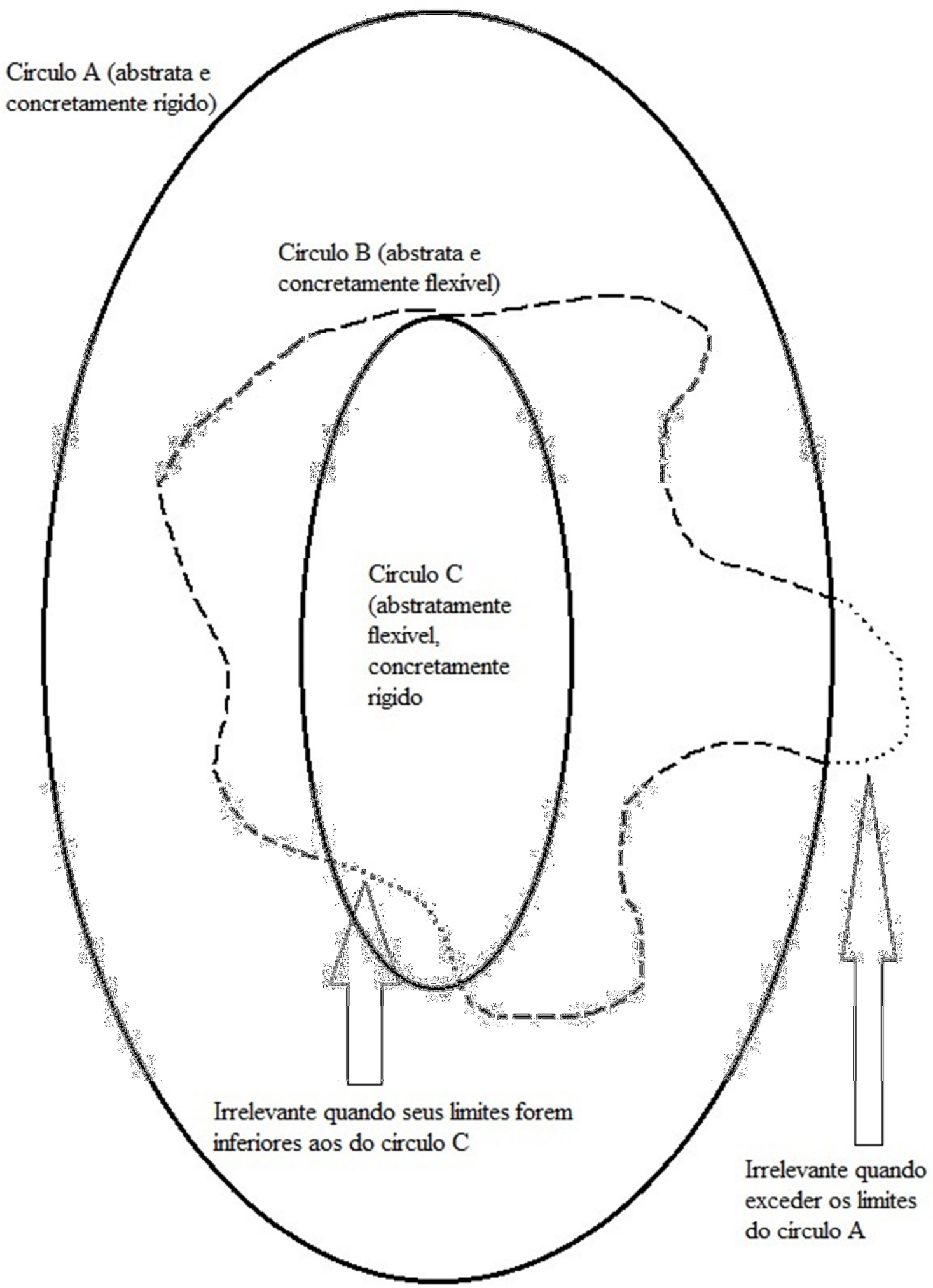

Nessa imagem, o círculo A correponde aos limites da linguagem, o círculo B à delimitação pelo contraditório e o círculo $\mathrm{C}$ dos limites mínimos exigidos pela função justificativa. 
Limites da motivação que devem ser atingidos no caso concreto para que se possa considerar que a decisão foi adequadamente justificada

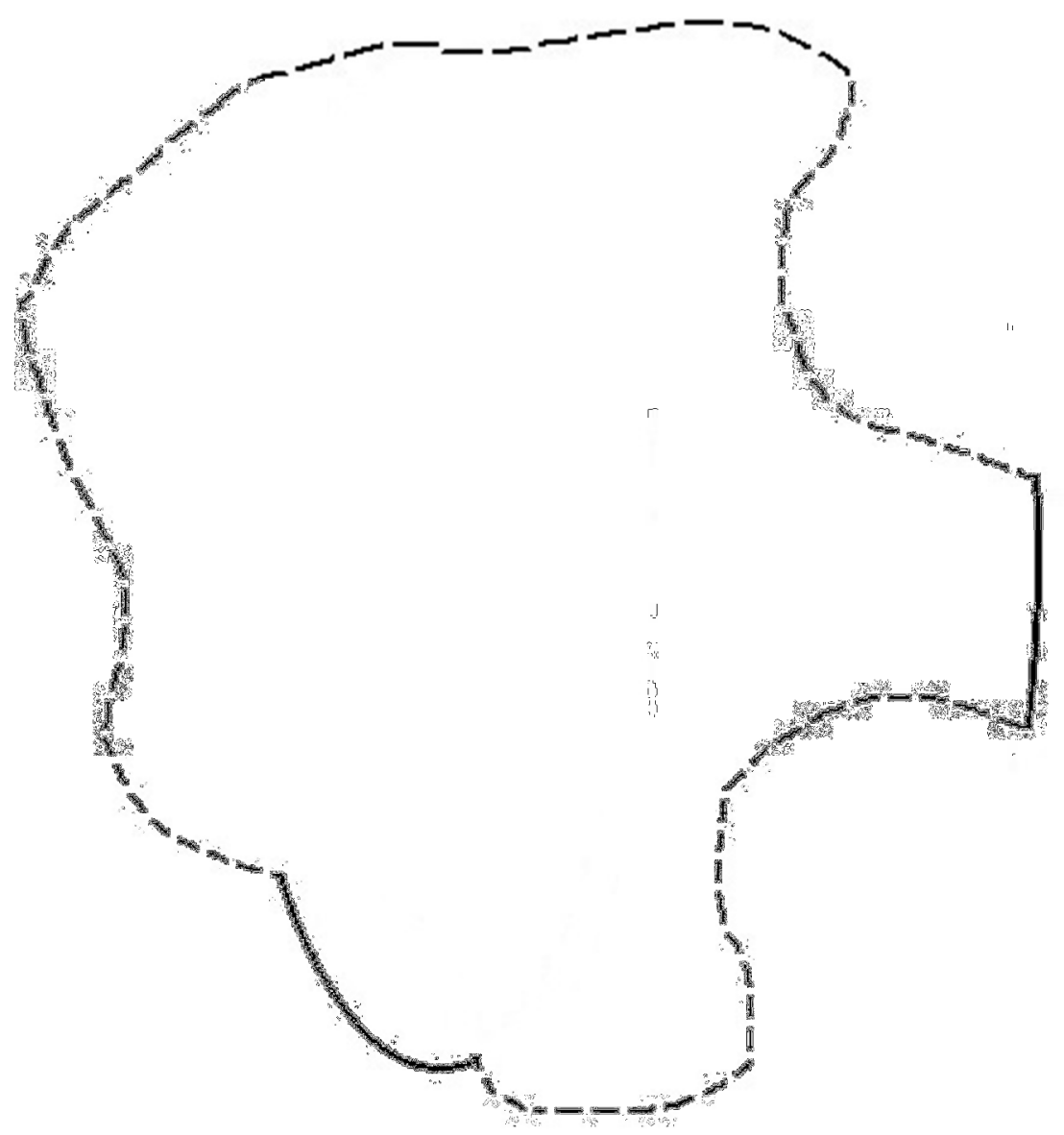




\section{Alguns víCios de motivação COMUNS}

Diante da estrutura definida no Capítulo 3, é possível analisar algumas situações em que comumente a exigência de motivação das decisões judiciais não é satisfeita. Não se pretende compor um quadro completo de todas as situações típicas de insuficiência de motivação, mas apenas chamar atenção para algumas situações comuns nas quais o modelo descrito no Capítulo anterior não é atendido. Assim, serão objeto de análise a motivação per relationem (item 4.1), a motivação implícita (item 4.2) e a motivação sobre a determinação dos fatos (item 4.3)

\subsection{Motivação per relationem}

Um vício da motivação comum na prática é a motivação per relationem. ${ }^{247}$ Há motivação per relationem sempre que o juiz deixa de justificar uma decisão por ter feito referência à fundamentação de outra decisão. Isso pode ocorrer tanto quando o juiz de grau recursal faz referência à motivação da decisão recorrida, como quando se faz referência à motivação de decisão prolatada em processo diferente.

Se o dever de motivação for entendido sob a ótica de sua estrutura e de sua função extraprocessual, a motivação per relationem não deve ser admitida. Isso não significa que a motivação e.g. do julgamento de uma apelação deva ser completamente diferente da motivação da sentença apelada, mas que deve conter justificação própria autônoma e conformada à decisão tomada em segunda instância que, evidentemente, é diferente daquela da instância inferior ${ }^{248}$.

A referência a decisões tomadas em outros processos pode exercer a função de obiter dictum ou servir como raciocínio tópico para a motivação - ao recuperar máximas e orientações consolidadas. Nesses casos, não se pode dizer que haja defeito na

\footnotetext{
247 Amplamente admitida pelos Tribunais de superposição: STF, 2 ${ }^{\mathbf{a}}$ Turma, ARE n. 727030, Rel. Min. GilmaR MEndes, j. 19.11.2013, DJe 2.12.2013; STF, $2^{\mathrm{a}}$ Turma, ARE n. 753481, Rel. Min. CELSO DE MEllo, j. 24.9.2013, DJe 25.10.2013; STJ, $1^{\text {a }}$ Turma, AgRg no REsp n. 1220823, Rel. Min. SÉRGIO KuKINA,

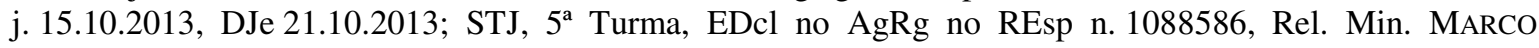
AURÉLIO BELliZZE, j. 17.9.2013, DJe 26.09.2013.

${ }^{248}$ TuCCI, José Rogério Cruz e, A motivação da sentença no processo civil, cit. n. 3, pp. 19.
} 
motivação ${ }^{249}$. No entanto, se a referência a decisões tomadas em outros processos substituir completamente a motivação, o dever de fundamentar as decisões deixa de ser atendido pois, nesse caso, haverá uma não motivação, que não pode ser controlada. ${ }^{250}$

\subsection{Motivação implícita}

Quanto à motivação implícita, a jurisprudência ${ }^{251}$ dos Tribunais Superiores entende que o juiz não tem o dever de analisar todos os argumentos aduzidos pelas partes nem todas as fontes de prova, de modo que os argumentos contrários à decisão e os resultados de prova divergentes em relação à determinação dos fatos expressa na motivação devem ser considerados implicitamente rejeitados. ${ }^{252}$ Essa orientação pode ser interpretada no sentido de que alegações e fontes de prova que não tenham nenhuma relevância não precisam ser expressamente analisadas e rejeitadas na motivação, o que, para TARUFFO, seria razoável, ${ }^{253}$ opinião com a qual não se pode concordar.

Entendido o contraditório como direito a influir na formação da decisão judicial, deixa de fazer sentido entender que o juiz não tem que analisar e motivar o acolhimento ou rejeição de todas as alegações das partes. Nessa perspectiva, mesmo as alegações ou requerimentos de produção de prova que o juiz entenda serem absurdas deverão ser rejeitadas fundamentadamente, mesmo que a fundamentação se limite a declarar o absurdo da alegação ou dos requerimentos de produção de prova. ${ }^{254}$

\footnotetext{
${ }^{249}$ BADARÓ, Gustavo Henrique Righi Ivahy, Vícios de motivação da sentença penal: ausência de motivação, motivação contraditória, motivação implícita e motivação per relationem, cit. n. 21, p. 138.

${ }^{250}$ TARUFFo, Michele, La motivazione della sentenza civile, cit. n. 1, pp. 422-429; CABRAL, Antonio do Passo, Nulidades no processo moderno: contraditório, proteção da confiança e validade prima facie dos atos processuais, cit. $n .70$, p. 295; BADARÓ, Gustavo Henrique Righi Ivahy, Vícios de motivação da sentença penal: ausência de motivação, motivação contraditória, motivação implícita e motivação per relationem, cit. n. 21, p. 137. Em sentido contrário, GOMES FILHO entende que o recurso à motivação ad relationem não implica descumprimento ao dever de fundamentação das decisões desde que (i) a fundamentação a que se faz referência seja aplicável ao caso em discussão; (ii) a decisão que faça referência e a decisão a que se faz referência tenham, sido tomadas com a mesma profundidade de cognição; (iii) que o texto a que se faz referência provenha de parte legítima a motivar a decisão - o que exclui e.g. a referência acrítica ao laudo pericial -; e (iv) que o texto a que se faz referência anteceda cronologicamente o texto que faz referência, conforme A motivação das decisões penais, cit. $n$. 24, pp. 197-199; A garantia da motivação das decisões judiciais na Constituição de 1988, cit. n. 21, pp. 81-82. O parâmetro para aferição da suficiência da motivação estabelecido supra 3.7 impõe que se rejeite a motivação per relationem em qualquer circunstância. ${ }^{251}$ STJ, $5^{\mathrm{a}}$ Turma, HC n. 220836, Rel. Min. MARCO AuRÉlio BellizZE, j. 9.4.2013, DJe 16.4.2013; STF, $2^{\mathrm{a}}$ Turma, HC n. 84383, Rel. Min. CeZAR Peluso, j. 31.10.2006, DJ 7.12.2006.

${ }^{252}$ TuCCI, José Rogério Cruz e, A motivação da sentença no processo civil, cit. n. 3, p. 19.

${ }^{253}$ TARUFFO, Michele, La motivazione della sentenza civile, cit. n. 1, pp. 430-436.

${ }^{254}$ Bueno, Cássio Scarpinella, Curso sistematizado de direito processual civil, v. 1, cit.n. 51, p. 135; Comentário ao artigo 458, cit. n. 73, p. 1430.
} 
O abuso do direito ao contraditório não pode ser sancionado com a diminuição do dever de fundamentação, até porque o juiz já dispõe de mecanismos aptos a sancionar esse abuso. Na esfera civil, pode impor a multa por litigância de má-fé prevista no artigo 17 do Código de Processo Civil. Na esfera penal, embora não exista previsão de multa por litigância de má-fé, isso não significa que esta não possa ser sancionada. O Superior Tribunal de Justiça vem decidindo ${ }^{255}$ que a interposição de recurso com caráter protelatório é capaz de afastar a necessidade de aguardar o trânsito em julgado para que se inicie o cumprimento da pena. Por fim, em ambas as esferas, a violação ao dever de boa-fé na esfera profissional pode dar origem à nulificação do ato. ${ }^{256}$

Outra interpretação dessa orientação é a de que permite que o juiz omita a motivação sobre qualquer alegação, fonte de prova ou argumento contrários ao que se decidiu. Essa orientação também deve ser rejeitada, até por conta do caráter instrumental da motivação em relação ao direito ao contraditório.

A motivação implícita é mais grave quando se refere a alegações defensivas prejudiciais, ${ }^{257}$ que ampliam o objeto da cognição judicial. Isso porque da (justificação da) decisão sobre a questão principal não é possível deduzir a justificação sobre a questão defensiva prejudicial, mas tão-somente a rejeição dessa questão. ${ }^{258}$ Quanto à motivação implícita, é importante notar ainda que nem sempre a justificação da escolha de uma das alternativas implica a justificação da rejeição das demais, já que nem sempre existe incompatibilidade lógica entre as alternativas, o que impede que essa escolha seja motivada implicitamente. ${ }^{259}$

${ }^{255} 5^{\text {a }}$ Turma, AgRg nos EDcl no AgRg no AREsp n. 222493, Rel. Min. JoRgE MusSI, j. 20.6.2013, DJe 1.8.2013; $5^{\mathrm{a}}$ Turma, AgRg nos EDcl nos EDcl no AgRg no Ag n. 1020286, Rel. Min. CAMPOS MARQUES (Desembargador convocado do TJ/PR), j. 20.11.2012, DJe 26.11.2012; 5 ${ }^{\text {a }}$ Turma, AgRg no AgRg no AgRg no Ag n. 1425288, Rel. Min. MARCo AurÉLIo BellizZE, j. 25.9.2012, DJe 2.10.2012.

${ }^{256}$ CABral, Antonio do Passo, Nulidades no processo moderno: contraditório, proteção da confiança e validade prima facie dos atos processuais, cit. $n$. 70, pp. 234-235.

${ }^{257}$ E.g.: Alegações previstas no art. 301, CPC; alegação de fato modificativo, extintivo ou impeditivo.

${ }^{258}$ GOMES FILHO, Antonio Magalhães, A garantia da motivação das decisões judiciais na Constituição de 1988, cit. n. 21 , p. 81.

${ }^{259}$ TARUFFO, Michele, La motivazione della sentenza civile, cit. n. 1, pp. 430-436; BADARÓ, Gustavo Henrique Righi Ivahy, Vícios de motivação da sentença penal: ausência de motivação, motivação contraditória, motivação implícita e motivação per relationem, cit. n. 21, p. 132. 


\subsection{Motivação quanto à matéria fática}

Por conta de uma visão da atividade judiciária como aplicação do direito e não de resolução de conflitos, a motivação costuma ser mais completa na exposição dos momentos do raciocínio jusitificativo ligados à fixação da norma do que aqueles ligados à determinação dos fatos. ${ }^{260}$ Disso resulta uma série de deficiências da justificação fática da decisão, seja quanto à admissibilidade (item 4.3.1), mas principalmente quanto à valoração (item 4.3.2) das provas.

Antes da análise dos casos em que a determinação dos fatos não é suficientemente motivada, cabem algumas observações de ordem terminológica. Para os fins deste trabalho, elemento de prova é um dado objetivo que confirma ou nega "uma asserção a respeito de um fato que interessa à decisão da causa". ${ }^{261}$ Esse dado é extraído de uma fonte de prova, que é uma pessoa ou coisa que pode trazer informações úteis à convicção do juiz. Meio de prova, por sua vez é o instrumento por meio do qual o elemento de prova é transportado do mundo dos fatos para o processo. Finalmente, resultado da prova, por sua vez, é a conclusão que se extrai dos elementos de prova após sua valoração. ${ }^{262}$

\subsubsection{Juízo de admissibilidade de provas}

Costuma-se ${ }^{263}$ reconhecer a desnecessidade de motivação quanto à admissibilidade de provas. Nesse ponto, TARUFFO entende que, embora o juiz não tenha que motivar a inadmissão da produção de toda e qualquer prova solicitada pelas partes, tem que motivar a inadmissão da produção dos meios de prova que pareçam, a primeira vista, admissíveis e relevantes.

No entanto, como já foi dito, entendido o contraditório como direito a influir na formação da decisão judicial, deixa de fazer sentido entender que o juiz não tem que analisar e

\footnotetext{
${ }^{260}$ TARUFFO, Michele, La motivazione della sentenza civile, cit. n. 1, p. 437; GOMES FILHO, Antonio Magalhães, A motivação das decisões penais, cit. n. 24, p. 145.

${ }^{261}$ GOMES FILHO, Antonio Magalhães, Notas sobre a terminologia da prova (reflexos no processo penal brasileiro) in Estudos em homenagem à Professora Ada Pellegrini Grinover, coord. MoRAES, Mauricio Zanoide de e Yarshell, Flávio Luiz, São Paulo, DPJ, 2005, pp. 307-309; ToNINI, Paolo, La prova penale, $4^{\mathrm{a}}$ ed., Padova, CEDAM, 2000, p. 32.

${ }^{262}$ GOMES FILHO, Antonio Magalhães, Notas sobre a terminologia da prova (reflexos no processo penal brasileiro), cit. n. 261, pp. 307-309; TONINI, Paolo, La prova penale, cit. $n$. 261, p. 32.

${ }^{263}$ STF, $1^{\text {a }}$ Turma, ARE n. 696563, Rel. Min. LuIZ FuX, j. 30.10.2012, DJe 3.12.2012.
} 
motivar o acolhimento ou rejeição de todas as alegações das partes. Nessa perspectiva, mesmo as alegações ou requerimentos de produção de prova que o juiz entenda serem absurdas deverão ser rejeitadas fundamentadamente, ainda que a fundamentação se limite a declarar o absurdo da alegação ou requerimentos de produção de prova. ${ }^{264}$

O abuso do direito ao contraditório não pode ser sancionado com a diminuição do dever de fundamentação, até porque o juiz já dispõe de mecanismos aptos a sancionar esse abuso. Na esfera civil, pode impor a multa por litigância de má-fé prevista no artigo 17 do Código de Processo Civil. Na esfera penal, embora não exista previsão de multa por litigância de má-fé, isso não significa que esta não possa ser sancionada. O Superior Tribunal de Justiça vêm decidindo ${ }^{265}$ que a interposição de recurso com caráter protelatório é capaz de afastar a necessidade de aguardar o trânsito em julgado para que se inicie o cumprimento da pena. Por fim, em ambas as esferas, a violação ao dever de boa-fé na esfera profissional pode dar origem à nulificação do ato ${ }^{266}$.

Os motivos da inadmissão da produção de um meio de prova não podem reputar-se implícitos do fato de o juiz ter fundado seu convencimento sobre outros meios de prova. Desse convencimento só é implícita a própria decisão de inadmissão do meio de prova. Ademais, admitir a possibilidade de não motivar a inadmissão da produção de um meio de prova significa esvaziar o conteúdo do direito à prova. ${ }^{267},{ }^{268}$

Outra consequência grave da ausência de motivação específica quanto à inadmissão da produção de um meio de prova diz respeito à função extraprocessual da motivação, de permitir o controle democrático da atividade jurisdicional. Isso porque esse controle só é

\footnotetext{
${ }^{264}$ BuEno, Cássio Scarpinella, Curso sistematizado de direito processual civil, v. 1, cit. n. 51, p. 135; Comentário ao artigo 458, cit. $n .73$, p. 1430.

${ }^{265} 5^{\mathrm{a}}$ Turma, AgRg nos EDcl no AgRg no AREsp n. 222493, Rel. Min. JORGE Mussi, j. 20.6.2013, DJe 1.8.2013; $5^{\mathrm{a}}$ Turma, AgRg nos EDcl nos EDcl no AgRg no Ag n. 1020286, Rel. Min. CAMPOS MARQUES (Desembargador convocado do TJ/PR), j. 20.11.2012, DJe 26.11.2012; 5 ${ }^{\text {a }}$ Turma, AgRg no AgRg no AgRg no Ag n. 1425288, Rel. Min. MArCo AurÉLIo BellizZE, j. 25.9.2012, DJe 2.10.2012.

${ }^{266}$ CABRAL, Antonio do Passo, Nulidades no processo moderno: contraditório, proteção da confiança e validade prima facie dos atos processuais, cit. $n$. 70, pp. 234-235.

${ }^{267}$ BADARÓ, Gustavo Henrique Righi Ivahy, Vícios de motivação da sentença penal: ausência de motivação, motivação contraditória, motivação implícita e motivação per relationem, cit. n. 21, p. 132; GOMES FILHO, Antonio Magalhães, A motivação das decisões penais, cit. n. 24, p. 150.

${ }^{268}$ Que se configura como direito autônomo, desvinculado de sua função instrumental ao contraditório, conforme BergeAud, Aurélie, Le droit à la preuve, Paris, LGDJ, 2010, passim; YARSHELl, Flávio Luiz, Antecipação da prova sem o requisito da urgência e direito autônomo à prova, São Paulo, Malheiros, 2009, passim.
} 
possível se forem conhecidos os elementos que poderiam levar a uma decisão em sentido contrário. $^{269}$

Assim, há necessidade de justificação explícita de todas as etapas relacionadas com o juízo de fato $^{270}$, quais sejam a admissibilidade, pertinência, relevância e valoração. ${ }^{271}$ A decisão quanto à admissibilidade das provas exige a verificação dos requisitos legais para a entrada da prova no processo e a decisão quanto à relevância das provas é uma seleção lógica dessas provas que exige a verificação da utilidade das mesmas para o julgamento. As provas que passarem por esses dois testes serão, então, valoradas. ${ }^{272}$

\subsubsection{Valoração das provas}

Da mesma maneira que se admite que a inadmissão da produção de um meio de prova seja motivada implicitamente a partir do fato de o juiz ter fundado sua escolha sobre a determinação dos fatos em outros meios de prova, também se admite a motivação implícita da valoração da prova em sentido contrário da escolha do juiz. Também nesse caso, admitir-se a motivação implícita significa esvaziar o direito à prova, uma vez que esse direito perde sua importância se o juiz puder injustificadamente deixar de considerar uma prova apta a infirmar seu raciocínio. ${ }^{273}$

A discricionariedade que o livre convencimento permite ao juiz não exclui a necessidade da motivação das escolhas que o juiz faz na determinação dos fatos. ${ }^{274} \mathrm{Na}$ verdade, essa discricionariedade implica a necessidade de justificação. Essa última afirmação encontra fundamento tanto na estrutura funcional da motivação, que prevê a necessidade de justificação das escolhas discricionárias, quanto na função extraprocessual da motivação — de permitir o controle democrático da atividade jurisdicional. Sob a ótica da função

\footnotetext{
${ }^{269}$ TARUFFO, Michele, La motivazione della sentenza civile, cit. $n$. 1, pp. 437-440.

${ }^{270}$ GOMES FILHO, Antonio Magalhães, A motivação das decisões penais, cit. n. 24, p. 101.

${ }^{271}$ GoMes FILHO, Antonio Magalhães, A motivação das decisões penais, cit. n. 24, p. 150; A garantia da motivação das decisões judiciais na Constituição de 1988, cit. n. 21, p. 73.

${ }^{272}$ GOMES FILHO, Antonio Magalhães, A garantia da motivação das decisões judiciais na Constituição de 1988, cit. n. 21, p.74.

${ }^{273}$ TARUFFO, Michele, La motivazione della sentenza civile, cit. n. 1, pp. 440-443; GOMES FILHO, Antonio Magalhães, A motivação das decisões penais, cit. n. 24, p. 153; A garantia da motivação das decisões judiciais na Constituição de 1988, cit. n. 21, p.75.

${ }^{274}$ GOMES FILHO, Antonio Magalhães, A garantia da motivação das decisões judiciais na Constituição de 1988, cit. n. 21, p.74.
} 
extraprocessual da motivação, é a justificação das decisões discricionárias e a consequente possibilidade de controle que evita que a discricionariedade degenere-se em arbitrariedade.

Ao se permitir que o juiz fundamente a determinação dos fatos que levaram ao seu convencimento de maneira global, sem referência à avaliação de cada fonte de prova ${ }^{275}$ esvazia-se o conteúdo da motivação quanto à determinação dos fatos, uma vez que não se explicitam os critérios cognoscitivos - que determinam a racionalidade do raciocínio inferencial — aplicáveis a cada fonte de prova. ${ }^{276}$

O processo de valoração das provas, na realidade, refere-se a dois momentos distintos. No primeiro momento, o juiz analisa cada elemento de prova, isoladamente, quanto à atendibilidade, idoneidade, credibilidade e autenticidade. No segundo momento, o juiz realiza uma série de inferências sobre cada um desses elementos de prova que tenha superado a primeira análise e chega ao resultado de prova. ${ }^{277}$

O âmbito da valoração das provas é rico em exemplos de vícios de motivação, motivo pelo qual será estudado de maneira mais aprofundada. É possível, nesse âmbito, destacar os debates sobre o conflito entre livre convencimento e manifestações do sistema legal de valoração de prova (item 4.3.2.1); a função heurística e tópica dos modelos de constatação, apta a racionalizar muitos dos debates sobre valoração da prova (item 4.3.2.2); bem como os problemas na valoração dos indícios (item 4.3.2.3) e da prova pericial (item 4.3.2.4).

Os dois temas de estudo mais aprofundado quanto à valoração da prova são importantes porque são capazes de demonstrar algumas dificuldades da prática que afastam a motivação do modelo proposto no Capítulo 3. A dificuldade na valoração dos indícios é sintomática da não superação do paradigma silogístico, baseado em deduções, uma vez que, no caso dos indícios, a inferência na determinação não assume a forma de uma dedução. Os problemas na valoração da prova pericial, por sua vez, indicam a dificuldade de atender o requisito de racionalidade da fundamentação.

\footnotetext{
275 GOMES FILHO, Antonio Magalhães, A motivação das decisões penais, cit. $n$. 24, pp. 158-159.

${ }^{276}$ TARUFFO, Michele, La motivazione della sentenza civile, cit. $n$. 1, pp. 443-449.

${ }^{277}$ Gomes FILHO, Antonio Magalhães, A motivação das decisões penais, cit. n. 24, p. 154; A garantia da motivação das decisões judiciais na Constituição de 1988, cit. n. 21, p.74.
} 


\subsubsection{Livre convencimento}

A discricionariedade do juiz em matéria probatória decorre do livre convencimento. Para melhor entendê-lo, é necessária uma breve digressão histórica.

O primeiro modelo de valoração da prova adotado pelas sociedades humanas é o sistema do livre convencimento, ou da convicção íntima. É o sistema da "justiça de cádi", ${ }^{278}$ que tem como objetivo resolver o problema que se apresenta de acordo com a concepção pessoal de justiça do juiz. Nesse sistema, sequer importa a distinção entre fato e direito. Isso porque o juiz decide da maneira que considera justa, muitas vezes de maneira contrária à norma abstrata que seria aplicável e aos fatos trazidos aos autos, até porque o juiz pode levar em conta fatos que não estejam nos autos (isto é, seu conhecimento privado). ${ }^{279}$ Nesse sistema, a liberdade de valoração da prova é a mais ampla possível, até porque o juiz sequer tem que motivar suas decisões. ${ }^{280}$

Em relação à possibilidade de arbítrio do juiz, esse sistema foi substituído pelo sistema da “prova legal". ${ }^{281}$ Esse sistema acompanha toda uma visão do processo típica do processo eclesiástico, que é um processo escrito, formal e inquisitório. ${ }^{282}$ Especificamente quanto à valoração da prova, nesse sistema o juiz tem pouca ou nenhuma liberdade para valorar a prova. Isso porque é a lei que, de antemão, define quais os meios de prova aptos a demonstrar a ocorrência de determinados fatos, além de já valorar a prova. ${ }^{283}$ A lei determina quais meios de prova devem prevalecer sobre os outros e quais/quantos meios de prova são capazes de fornecer a certeza suficiente para considerar ocorrido um fato. $\mathrm{O}$

\footnotetext{
${ }^{278}$ WeBER, Max, Wirtschaft und Gesellschaft: Grundiss der versteheden Soziologie, cit. n. 66, p. 518.

${ }^{279}$ POZZA, Pedro Luiz, Sistemas de valoração da prova in Prova judiciária: estudos sobre o novo direito probatório, coord. KNIJNIK, Danilo, Porto Alegre, Livraria do Advogado, 2007, pp. 230, 231; LACERDA, Maria Francisca dos Santos e ZAGANELLI, Margareth Vetis, Livre apreciação da prova, ciência e raciocínio judicial: considerações sobre a 'cientifização' da prova no processo, cit.n. 69, p. 155; GARCIA, André Almeida, Prova Civil, cit. n. 51, p. 71.

${ }^{280}$ Mitidiero, Daniel, Comentários ao Código de Processo Civil, t. 1, São Paulo, Memória Jurídica, 2004, p. 555; Garcia, André Almeida, Prova Civil, cit. n. 51, p. 72; GoMes FILHO, Antonio Magalhães, A motivação das decisões penais, cit. n. 24, pp. 145-148; Provas, cit. n. 98, pp. 248-249.

${ }^{281}$ PozZA, Pedro Luiz, Sistemas de valoração da prova, cit. n. 279, p. 220; GARCIA, André Almeida, Prova Civil, cit. n. 51, p. 70.

${ }^{282}$ POZZA, Pedro Luiz, Sistemas de valoração da prova, cit. $n .279$, p. 227. Outros entendem que a origem do sistema da prova legal está no modelo dos povos germânicos durante a Alta Idade Média. Nesse sentido, ReICHELt, Luis Alberto, A prova no direito processual civil, Porto Alegre, Livraria do Advogado, 2009, pp. 25-28.

${ }^{283}$ LACERDA, Maria Francisca dos Santos e ZAGANELLI, Margareth Vetis, Livre apreciação da prova, ciência e raciocínio judicial: considerações sobre a 'cientifização' da prova no processo, cit. $n$. 69 , p. 151; GARCIA, André Almeida, Prova Civil, cit. n. 51, p. 68.
} 
juiz, portanto, pode tomar sua decisão somente com base nos fatos que pode considerar que ocorreram de acordo com a aplicação dessas normas que valoram de antemão a prova. ${ }^{284}$

Embora o sistema de valoração legal da prova não esteja imune de críticas é certo que algumas críticas a ele dirigidas são exageradas. Critica-se $\mathrm{s}^{285}$ que o sistema de valoração legal da prova seria irracional. Essa crítica não leva em conta, no entanto, que a valoração dos meios de prova pelo legislador refletia a visão de mundo da época, o "quod plerumque accidit", segundo aquela sociedade. ${ }^{286}$ Outras críticas, porém, procedem. Um dos problemas da valoração legal da prova é exatamente a mudança na sociedade, de modo que a hierarquia entre meios de prova que pode ser enxergada como razoável em dado momento pode ser considerada ultrapassada após alguns anos. Essa dificuldade de e demora na adaptação às mudanças na sociedade ocorre em todo mecanismo jurídico que só pode ser alterado por reforma legislativa. Outro problema refere-se à impossibilidade de que uma valoração da prova feita de antemão, por mais racional que seja, dê sempre a solução correta à questão fática do caso. Isso porque o mundo e a sociedade são de tal maneira complexos que é impossível prever todas as combinações de situações possíveis. Assim, a valoração legal da prova inevitavelmente conduzirá a resultados considerados aberrantes em situações específicas.

A resposta a essas duas falhas do sistema de valoração legal da prova apontadas nas críticas acima foi um "retorno" ao sistema do livre convencimento. ${ }^{287}$ A expressão está entre aspas, porque de retorno não se tratou, uma vez que o sistema de valoração da prova que sucedeu o sistema de valoração legal da prova é o sistema da livre convicção racional. Segundo esse sistema, o juiz pode valorar livremente a prova, mas deve fazê-lo de maneira racional $^{288}$ e só pode levar em conta elementos de prova que estejam nos autos. ${ }^{289,290} \mathrm{O}$

\footnotetext{
${ }^{284}$ POZZA, Pedro Luiz, Sistemas de valoração da prova, cit. n. 279, p. 220.

${ }^{285}$ LACERDA, Maria Francisca dos Santos e ZAGANELLI, Margareth Vetis, Livre apreciação da prova, ciência e raciocínio judicial: considerações sobre a 'cientifização' da prova no processo, cit. $n .69$, p. 154.

${ }^{286}$ DAMASKA, Mirjan R., Rational and Irrational Proof Revisited, Faculty Scholarship Series. Paper 1577, http://digitalcommons.law.yale.edu/fss_papers/1577, 1997, p. 36.

${ }^{287} \mathrm{Na}$ Alemanha a resposta inicial foi impor o sistema da prova legal somente para a condenação em processo penal vigorando o sistema do livre convencimento nos demais caso, conforme PozZA, Pedro Luiz, Sistemas de valoração da prova, cit. n. 279, p. 230.

${ }^{288}$ CÂMARA, Alexandre Freitas, A valoração da prova genética: está o juiz vinculado ao resultado do exame de ADN? in Provas: aspectos atuais do direito probatório, coord. NEVES, Daniel Amorim Assumpção, Rio de Janeiro, Forense, 2009, p. 18; LACERDA, Maria Francisca dos Santos e ZAGANELLI, Margareth Vetis, Livre apreciação da prova, ciência e raciocínio judicial: considerações sobre a 'cientifização' da prova no processo, cit. n. 69, p. 157; GARCIA, André Almeida, Prova Civil, cit.n. 51, pp. 74-76; GARCIA, Francisco de Assis, Da prova pericial no processo civil, Dissertação (Mestrado) - Faculdade de Direito de USP, São
} 
controle da racionalidade dessa valoração se dá por meio da motivação ${ }^{291}$ da decisão - daí também ser chamado de sistema do livre convencimento motivado.

O livre convencimento do juiz encontra limites não só em seu aspecto racional como também na própria legislação. A leitura do artigo $131^{292}$ do Código de Processo Civil leva a conclusão de que o Brasil adotou, em seu processo civil, o sistema do livre convencimento motivado. Outros dispositivos, ${ }^{293}$ porém, indicam uma valoração legal da prova. Qual é, então, o sistema de valoração da prova adotado pelo Código de Processo Civil?

Existe quem defenda que o Código de Processo Civil adota o sistema do livre convencimento motivado, sem qualquer exceção (infra 4.3.2.1.1) e existe quem defenda que, embora se adote o sistema do livre convencimento motivado, existem exceções a esse sistema, que devem ser observadas (infra 4.3.2.1.2). Após a análise crítica dessas duas posições, será exposta uma construção que pretende escapar dessas críticas (infra 4.3.2.1.3).

Paulo, 2000, p. 70; TuCCI, José Rogério Cruz e, A motivação da sentença no processo civil, cit. n. 3, pp. 102104.

${ }^{289}$ POZZA, Pedro Luiz, Sistemas de valoração da prova, cit. n. 279, p. 233; CÂMARA, Alexandre Freitas, A valoração da prova genética: está o juiz vinculado ao resultado do exame de ADN?, cit. n. 288, p. 18; LACERDA, Maria Francisca dos Santos e ZAGANELLI, Margareth Vetis, Livre apreciação da prova, ciência e raciocínio judicial: considerações sobre a 'cientifização' da prova no processo, cit. n. 69, p. 158; GARCIA, André Almeida, Prova Civil, cit. n. 51, pp. 74-76; MOTULSKY, Henri, Écrits: études et notes de procédure civile, cit. n. 64, p. 41.

${ }^{290}$ Isso não significa, no entanto, que o juiz esteja adstrito às provas que as partes considerem importantes. Ele pode julgar com base em qualquer elemento dos autos, conforme MOTULSKY, Henri, Écrits: études et notes de procédure civile, cit. $n$. 64 , pp. 55-56.

${ }^{291}$ POZZA, Pedro Luiz, Sistemas de valoração da prova, cit. n. 279, p. 234; GARCIA, André Almeida, Prova Civil, cit. n. 51, pp. 74-76; GoMes FilHo, Antonio Magalhães, Provas, cit. n. 98, pp. 248-249.

292 "O juiz apreciará livremente a prova, atendendo aos fatos e circunstâncias constantes dos autos, ainda que não alegados pelas partes; mas deverá indicar, na sentença, os motivos que lhe formaram o convencimento".

${ }^{293}$ E.g. CPC, art. 319: "se o réu não contestar a ação, reputar-se-ão verdadeiros os fatos afirmados pelo autor"; art. 401: "a prova exclusivamente testemunhal só se admite nos contratos cujo valor não exceda o décuplo do maior salário mínimo vigente no país, ao tempo em que foram celebrados"; art. 145, caput: "quando a prova do fato depender de conhecimento técnico ou científico, o juiz será assistido por perito, segundo o disposto no art. 421"; art. 335: "em falta de normas jurídicas particulares, o juiz aplicará as regras de experiência comum subministradas pela observação do que ordinariamente acontece e ainda as regras da experiência técnica, ressalvado, quanto a esta, o exame pericial"; art. 400: "a prova testemunhal é sempre admissível, não dispondo a lei de modo diverso. O juiz indeferirá a inquirição de testemunhas sobre fatos: I já provados por documento ou confissão da parte; II - que só por documento ou por exame pericial puderem ser provados"; art. 364: "o documento público faz prova não só da sua formação, mas também dos fatos que o escrivão, o tabelião, ou o funcionário declarar que ocorreram em sua presença". 


\subsection{Prevalência do livre convencimento racional}

Uma questão interessante a ser enfrentada relativa a vícios comuns na motivação das sentenças quanto ao aspecto fático diz respeito aos limites do livre convencimento no ordenamento brasileiro. Parte da doutrina ${ }^{294}$ e da jurisprudência acredita que o Código de Processo Civil Brasileiro adotou integralmente o sistema do livre convencimento motivado. Assim, em virtude da possibilidade de valorar livremente a prova o juiz poderia, por exemplo, permitir a produção de prova testemunhal de contratos cujo valor exceda dez vezes o salário mínimo da data de sua celebração ${ }^{295}$ ou quando o fato já tiver sido provado por documento ou confissão. ${ }^{296} \mathrm{O}$ juiz também poderia ignorar o artigo 401, II, do Código de Processo Civil, considerando provado por meio de testemunho o que só poderia ter sido provado por meio de documento ou perícia. ${ }^{297} \mathrm{O}$ juiz poderia, ainda, decidir com base em sua ciência privada, mesmo quando o Código de Processo Civil lhe impõe a prova pericial. $^{298}$ (arts. 145 , caput e 335 )

Essa posição tem como fundamento, basicamente, duas ideias. A primeira ideia é de que o objetivo mais importante do processo é a descoberta da verdade real ${ }^{299}$ e qualquer norma que impeça ou dificulte a investigação da verdade real não pode prevalecer sobre o livre convencimento motivado, que permitiria que o juiz julgasse de acordo com a verdade real. Essa ideia, por sua vez, se justifica sob o argumento de que o único modo pelo qual o juiz pode solucionar de maneira satisfatória o conflito que se põe diante dele é aplicar

\footnotetext{
${ }^{294}$ GARCIA, André Almeida, Prova Civil, v. nota 3, pp. 79-80; CÂmARA, Alexandre Freitas, A valoração da prova genética: está o juiz vinculado ao resultado do exame de ADN?, cit.n. 288, pp. 18-19; GRECO, Leonardo, Garantias fundamentais do processo: o processo justo, cit. n. 69, p. 24; CORRÊA, Orlando de Assis, Sentença cível: elaboração e nulidades, cit. $n$. 164, pp. 46-48.

${ }^{295}$ Todos do STJ: $4^{a}$ Turma, AgRg no Ag n. 1106104, rel. Min. JOÃO OtÁVIO DE NORONHA, j. 10.5.2011, DJ 18.5.2011; $3^{\mathrm{a}}$ Turma, REsp n. 895792, rel. Min. PAUlO DE TARSO SANSEVERINO, j. 7.4.2011, DJ 25.4.2011; $3^{\mathrm{a}}$ Turma, AgRg no Ag n. 1319590, rel. Min. SIDNEI BENETI, j. 14.9.2010, DJ 28.9.2010; $4^{\mathrm{a}}$ Turma, REsp n. 256115, rel. Min. CARLOS Fernando MATHIAS, j. 20.11.2008, DJ 9.12.2008; 4 $4^{a}$ Turma, REsp n. 713073, rel. Min. Aldir PASSARINHO JUNIOR, j. 22.3.2005, DJ 9.5.2005; $2^{\text {a }}$ Seção, EREsp n. 263387, rel. Min. CASTRO FILHO, j. 14.8.2002, DJ 17.3.2003.

${ }^{296}$ Todos do STJ: $3^{\text {a }}$ Turma, REsp n. 846543, rel. Min. PAUlo DE TARso SANSEVERINO, j. 5.4.2011, DJ 11.4.2011; 4 4 Turma, REsp n. 979129, rel. Min. LUIS FeLIPE SALOMÃO, j. 2.4.2009, DJ 13.4.2009; $3^{\mathrm{a}}$ Turma, REsp n. 198497, rel. Min. ARI PARGENDLER, j. 28.9.1999, DJ 8.5.2000; 4ª Turma, REsp n. 5128, rel. Min. BARROS MONTEIRO, j. 16.4.1991, DJ 20.5.1991.

${ }^{297}$ Todos do STJ: $3^{\mathrm{a}}$ Turma, REsp n. 846543, rel. Min. PAUlo De TARso SANSEVERINO, j. 5.4.2011, DJ 11.4.2011; $2^{\mathrm{a}}$ Turma, REsp n. 146478, rel. Min. FranciUlli NeTTO, j. 10.10.2000, DJ 5.2.2001; a $^{\mathrm{a}}$ Turma, REsp n. 164219, rel. Min. GARCIA VIEIRA, j. 21.5.1998, DJ 24.8.1998.

${ }^{298}$ Todos do STJ: $4^{\text {a }}$ Turma, REsp n. 914329, rel. Min. JoÃo OtÁvio de Noronha, j. 4.8.2011, DJ 30.3.2012; $3^{\text {a }}$ Turma, AgRg no Ag n. 1206781, rel. Min. VASCO DELla GiustinA, j. 28.9.2010, DJ 14.10.2010.

${ }^{299}$ LACERDA, Maria Francisca dos Santos e ZAGANELLI, Margareth Vetis, Livre apreciação da prova, ciência e raciocínio judicial: considerações sobre a 'cientifização' da prova no processo, cit. n. 69, pp. 144-146.
} 
corretamente a norma jurídica aos fatos que ocorreram. Isso, por sua vez, só seria possível se os fatos transportados ao processo correspondessem, na maior medida possível ao que ocorreu na realidade.

O segundo fundamento dessa visão sobre a valoração da prova é a ideia segundo a qual o livre convencimento motivado é um princípio jurídico e que, por isso, prevaleceria sobre as regras em sentido contrário. Os dois fundamentos desta visão devem ser rejeitados. Em primeiro lugar será demonstrado o motivo pelo qual o segundo fundamento deve ser rejeitado.

Segundo os que defendem que o livre convencimento motivado do juiz deve prevalecer em qualquer situação, o livre convencimento racional é um princípio processual e, em virtude da maior importância dos princípios, esses prevalecem sobre as demais normas, regras. ${ }^{300}$ Essa asserção se funda sobre o equívoco de afirmar que princípios sempre prevalecem sobre regras.

Como já se viu (supra 2.3.3) tanto regras quanto princípios são normas, porque dizem o que deve ser. ${ }^{301}$ Não existe, portanto, relação hierárquica entre regra e princípio. Trata-se, tão-somente de normas jurídicas com estruturas diferentes. Essas normas, é certo, podem emitir comandos (aparentemente) contraditórios, como no problema que se discute, mas esse conflito não se resolve com a prevalência automática do princípio (novamente, v. supra 2.3.3). Por esse motivo deve ser rejeitada a ideia de que o livre convencimento motivado prevalecesse sobre as normas em sentido contrário porque seria um princípio.

Os que defendem que o livre convencimento motivado do juiz deve prevalecer em qualquer situação argumentam também que só por meio do livre convencimento é possível atingir - ou, ao menos, perseguir - a verdade real, o que seria o fim último do processo. A verdade real, no entanto, não é o fím último do processo $^{302}$ e sequer existe. Isso porque a busca pela verdade, sendo sempre regulada de acordo com regras pré-estabelecidas, acaba por resultar em uma verdade procedimental, que é a única verdade que se pode discutir. A

\footnotetext{
${ }^{300}$ SouZA, Wilson Alves de, Sentença civil imotivada: caracterização da sentença civil imotivada no direito brasileiro, cit. n. 51, p. 102.

${ }^{301}$ ALEXY, Robert, Theorie der Grundrecht, cit. n. 114, pp. 86-87.

302 PozZA, Pedro Luiz, Sistemas de valoração da prova, cit. $n$. 279, p. 231; GARCIA, André Almeida, Prova Civil, cit.n. 51, p. 60; LECLERC, Olivier, Le juge et l'expert: contribution à l'étude des rapports entre le droit et la science, cit. n. 169, p. 120.
} 
verdade, assim, varia, conforme o contexto ${ }^{303}$ (processo civil, processo penal, processos administrativos, etc.). No entanto, o fato de existirem "verdades" diferentes conforme o contexto não afasta o fato de ser ela sempre procedimental. Nesta perspectiva, a certeza judicial equivale à convicção (verdade subjetiva) ${ }^{304}$ do juiz diante do conjunto probatório de um processo, ${ }^{305}$ formado de acordo com as regras procedimentais pré-estabelecidas.

O objetivo do processo, por sua vez, é a resolução do conflito que se põe diante do juiz, pacificando-o. ${ }^{306}$ É certo que para haver pacificação social deve ser proferida uma decisão que tenha levado em conta uma versão dos fatos próxima à realidade. No entanto, para haver pacificação é necessário, antes de tudo, resolver o conflito. ${ }^{307}$ Isso significa que o processo tem que acabar. Ou seja, não pode perdurar indefinidamente em busca da verdade real. Esta, portanto, é limitada pela necessidade de o processo dar uma resposta, e dá-la de maneira célere. ${ }^{308}$

A busca da verdade no processo encontra limites não só na necessidade de resolver o conflito como também encontra limites na segurança jurídica e na intimidade dos indivíduos. Em virtude da segurança jurídica, mesmo uma decisão que tenha avaliado de maneira incorreta os fatos transita em julgado. ${ }^{309} \mathrm{Em}$ virtude do direito à intimidade a produção de determinadas provas — chamadas de provas ilícitas — é vedada pelo ordenamento. ${ }^{310}$

\footnotetext{
${ }^{303}$ BADARÓ, Gustavo Henrique Righi Ivahy, Ônus da prova no processo penal, São Paulo, RT, 2003, pp. 2436; KNIJNIK, Danilo, A prova nos juizos cível, penal e tributário, Rio de Janeiro, Forense, 2007, pp. 10-15.

${ }^{304}$ GARCIA, Francisco de Assis, Da prova pericial no processo civil, cit. $n$. 288 , pp. 78-79.

${ }^{305}$ RocCO, Alfredo, La sentenza civile, Milano, Giuffrè, 1962, p. 82

${ }^{306}$ Dalbignat-Deharo, Gaëlle, Verité scientifique et verité judiciaire en droit privé, Paris, LGDJ, 2004, p. 39; GARCIA, Francisco de Assis, Da prova pericial no processo civil, cit. n. 288, p. 79.

${ }^{307}$ GARCIA, André Almeida, Prova Civil, cit. n. 51, p. 61; LECLERC, Olivier, Le juge et l'expert: contribution à l'étude des rapports entre le droit et la science, cit. $n$. 169, pp. 120-121, 154; DALBIGNAT-DEHARO, Gaëlle, Verité scientifique et verité judiciaire en droit privé, cit. n. 306, pp. 36-37.

${ }^{308}$ Até em virtude do direito fundamental à duração razoável do processo estabelecido no artigo $5^{\circ}$, LXXVIII da Constituição Federal. Nesse sentido: LECLERC, Olivier, Le juge et l'expert: contribution à l'étude des rapports entre le droit et la science, cit. $n$. 169, p. 121.

${ }^{309}$ Idem, pp. 120-121.

${ }^{310}$ Constituição Federal, art. 5’, LVI: "são inadmissíveis, no processo, as provas obtidas por meios ilícitos”.
} 


\subsection{Teoria das "ilhas" de valoração legal da prova dentro de um "mar" de livre

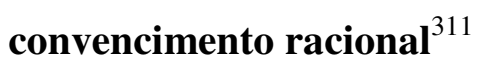

Da mesma maneira que a busca incessante pela verdade prejudica a celeridade do processo, a valoração legal da prova abrevia a duração do processo. A aceleração do processo por meio da valoração legal da prova se dá de duas maneiras: evita-se a produção de meios de prova que costumam atrasar o processo e simplifica-se o raciocínio que se exige do juiz.

A leitura dos dispositivos que preveem a valoração legal da prova demonstra que, em regra, o meio de prova que é dispensado é o testemunho (e.g. CPC, arts. 400 e 401). Ora, o indeferimento à produção de prova testemunhal traz, como regra, uma aceleração do processo, vez que pode evitar a realização de uma audiência ${ }^{312}$, que tem óbvias consequências deletérias para a celeridade do processo.

A valoração legal da prova também abrevia a duração do processo porque retira do juiz uma série de decisões que lhe tomariam tempo, seja para tomar a decisão, seja para fundamentá-la. Assim, aplicando os dispositivos do Código que preveem a valoração legal da prova ou critérios legais que determinam a (des)necessidade de produção de prova pericial, o juiz deixa de estar obrigado a tomar diversas decisões sobre a admissibilidade e valoração das provas.

A valoração legal também promove a segurança jurídica. Isso porque, ao estabelecer a maneira como um fato (ou um conjunto de fatos) deve ser encarado pelos juízes, unifica-se o raciocínio decisório quanto à determinação do fato em um conjunto enorme de casos. Assim, embora a determinação dos fatos não condicione necessariamente a decisão final, não há dúvida que a determinação de fatos em um mesmo sentido tende a fazer com que as decisões também sejam no mesmo sentido.

Não se pretende defender nesta dissertação que o artigo 131 do Código de Processo Civil deva ser revogado em virtude de suposta superioridade do sistema legal de valoração dos meios de prova. O que se quis demonstrar nos últimos parágrafos é que os dois sistemas

\footnotetext{
311 A expressão é de DinAmarco em Instituições de Direito Processual Civil, v. 3, 4a ed., São Paulo Malheiros, 2004, p.103.

${ }^{312}$ CPC, art. 410: "as testemunhas depõem, na audiência de instrução, perante o juiz da causa".
} 
têm suas vantagens e que o bom legislador, assim como o bom juiz, deve saber utilizar cada um nas situações corretas.

Nessa perspectiva, o sistema brasileiro de valoração da prova deve ser encarado como um "mar" de livre convencimento racional no qual existem "ilhas" de valoração legal da prova. ${ }^{313}$ Segundo essa orientação, os artigos $400^{314}$ e $401, \mathrm{I}^{315}$ e II ${ }^{316}$, do Código de Processo Civil $^{317}$ devem ser aplicados tal como consta da letra da lei embora nos outros casos o juiz continue podendo valorar livremente a prova. O juiz também estaria vinculado, quanto à admissibilidade da prova, pelos artigos 145 , caput, ${ }^{318}$ e $335,{ }^{319}$ do Código de Processo Civil, nas hipóteses em que esses dispositivos determinam ser necessária a produção de prova pericial.

No entanto, mesmo que a valoração legal da prova seja vista como um "arquipélago" em "mar" de livre convencimento, é certo que as mesmas críticas (v. supra, 4.3.2.1) feitas ao sistema de valoração legal da prova aplicam-se às normas específicas que valoram de antemão a prova. Surge, portanto, um dilema: como deve o aplicador se comportar quando a aplicação da regra legal de valoração da prova implicar resultado insuportavelmente injusto em um processo específico?

\subsection{Teoria da "maré"}

A resposta à pergunta formulada ao fim do ponto anterior encontra-se na teoria da "maré". Tal como a maré permite que o mar invada mais ou menos a ilha, a relação entre os dois sistemas de valoração da prova não pode ser estática. É necessário, portanto, que, em

313 PozZA, Pedro Luiz, Sistemas de valoração da prova, cit. n. 279, pp. 221-223. Na França DALBIGNATDEHARO, Gaëlle, Verité scientifique et verité judiciaire en droit privé, cit. n. 306, pp. 391-396.

${ }^{314}$ STJ, $5^{\text {a }}$ Turma, REsp n. 725914, rel. Min. FELIX FISCHER, j. 4.5.2006, DJ 5.6.2006.

${ }^{315}$ Todos do STJ: $1^{\mathrm{a}}$ Turma, REsp n. 323392, rel. Min. GARCIA VIEIRA, j. 26.6.2002, DJ 27.8.2001; $3^{\mathrm{a}}$ Turma, REsp n. 46071, rel. Min. CARlos Alberto Menezes Direito, j. 20.8.1996, DJ 14.10.1996; $3^{\mathrm{a}}$ Turma, REsp n. 4728, rel. Min. EDUARDO RIBEIRO, j. 26.11.1990, DJ 4.2.1991.

${ }^{316}$ STJ, $3^{\text {a }}$ Turma, REsp n. 1135150, rel. Min. NANCY ANDRIGHI, j. 5.4.2011, DJ 26.4.2011.

${ }^{317}$ A simples comparação quantitativa entre os acórdãos de acordo com a teoria exposta nesse ponto e a teoria exposta supra, 2.2.1 mostra a prevalência, na jurisprudência, da teoria da prevalência do livre convencimento motivado.

${ }^{318}$ Todos do STJ: $3^{\mathrm{a}}$ Turma, REsp n. 957347, rel. Min. NANCY ANDRIGHI, j. 22.3.2010, DJ 28.4.2010; $2^{\mathrm{a}}$ Turma, REsp n. 877541, rel. Min. EliAnA CALMON, j. 23.4.2009, DJ 19.5.2009; $1^{\text {a }}$ Turma, RMS n. 20048, rel. Min. José Delgado, j. 1.9.2005, DJ 26.9.2005; $3^{\mathrm{a}}$ Turma, REsp n. 317119, rel. Min. ANTÔNIO DE PÁDUA RIBEIRO, j. 4.11.2004, DJ 3.10.2005.

${ }^{319}$ Todos do STJ: $1^{\text {a }}$ Turma REsp n. 750988, rel. Min. LuIZ FuX, j. 17.8.2006, DJ 25.9.2006; $1^{\text {a }}$ Turma, REsp n. 40796, rel. Min. Milton LuIZ Pereira, j. 24.10.1994, DJ 28.11.1994; 4ª Turma, REsp n. 3003, rel. Min. ATHOS GUSMÃo CARNEIRO, j. 6.8.1991, DJ 9.12.1991. 
alguns casos específicos, diante de injustiças gritantes no caso concreto, o "mar" de livre convencimento racional cubra parte de uma das "ilhas" de valoração legal da prova.

Para explicar como funciona esse processo devemos voltar ao pensamento de ALEXY (ver, supra 2.3.3), especificamente para lembrar que muitas vezes as colisões entre princípios constitucionais são resolvidas pelo legislador, que prevê, por meio das regras infraconstitucionais, as hipóteses em que um princípio prevalece sobre o outro. Assim, para que no caso concreto a solução dada pelo legislador infraconstitucional seja superada pelo princípio constitucional por ele preterido, é necessário que este prepondere não só sobre o princípio que materialmente sustenta a regra (segundo a opção do legislador), mas também sobre o princípio segundo o qual as regras devem ser cumpridas, que sustenta formalmente essa regra (e todas as regras). ${ }^{320}$

No caso da relação entre prova legal e livre convencimento, o legislador infraconstitucional criou um sistema de normas (o "arquipélago") por meio do qual resolveu a colisão entre o princípio da justiça das decisões, de um lado e, de outro, o princípio da celeridade processual e da segurança jurídica.

Para que, no caso específico, o livre convencimento prevaleça sobre a valoração legal da prova aplicável ao caso, é necessário que em primeiro lugar, o princípio da justiça das decisões prevaleça na colisão sobre o princípio da celeridade processual e da segurança jurídica (que sustentam materialmente a decisão do legislador). É necessário, ainda, que prevaleça sobre o princípio segundo o qual as regras devem ser respeitadas.

Ou seja, para que o livre convencimento racional possa prevalecer sobre as regras de valoração legal da prova - ou seja, para que "a maré suba" - é necessária uma conjunção de fatores muito específica, que só se apresenta em situações nas quais a aplicação da norma de valoração legal da prova fosse implicar um resultado absolutamente inaceitável. Nesses casos, ademais, impõe-se ao juiz um ônus argumentativo tão grande que dificilmente essa possibilidade de deixar de aplicar a regra de valoração legal da prova implicaria um abandono, na prática, da teoria do "mar com ilhas" rumo à teoria de prevalência absoluta do livre convencimento racional.

${ }^{320}$ Theorie der Grundrecht, cit. n. 114, pp. 90-91, nota 24. 


\subsubsection{Modelos de constatação}

Uma das maneiras de impor racionalidade ao processo de tomada de decisões é a adoção de modelos de constatação. Os modelos de constatação indicam o grau de convicção necessário para que o juiz possa considerar ocorrido um fato em determinado âmbito. São, nesse sentido, enunciações teóricas compostas por um conjunto de regras lógicas que permitem um debate sobre a convicção judicial. Esse debate se torna possível porque a convicção passa a se exprimir de acordo com essas regras lógicas, cuja observância pode ser verificada pelas partes.

Os modelos de constatação permitem o controle do momento lógico no raciocínio de determinação dos fatos, não de seu momento axiológico-valorativo (ver, supra 3.5.2 e 3.6.1). Assim, delimitam um contexto comunicacional aberto no qual, a partir de um conjunto de linguagem comum, partes e juiz podem debater sobre a formação da convicção quanto à determinação dos fatos.

Nessa perspectiva, dizer e.g. que a prova de determinado fato está condicionada ao atingimento do modelo de constatação "mais provável do que não" abre o processo de determinação dos fatos ao contraditório, pois cria uma linguagem comum, na qual juiz e partes podem se comunicar ${ }^{321}$.

Assim, por exemplo, para que o juiz possa considerar ocorrido um fato no âmbito penal é necessário um grau de convicção maior do que para considerar ocorrido um fato no âmbito cível. Isso significa que os modelos de constatação usados pelo juiz nesses dois âmbitos são diferentes. ${ }^{322}$

Os modelos de constatação aos quais se costuma referir com maior frequência ${ }^{323}$ são: (i) o de preponderância de provas, segundo o qual a ocorrência de um fato deve ser mais provável que a sua não-ocorrência; (ii) o de prova clara e convincente, superior ao de preponderância, mas inferior ao de; (iii) prova além da dúvida razoável, segundo o qual a

\footnotetext{
${ }^{321}$ KNIJNIK, Danilo, A prova nos juízos cível, penal e tributário, cit. n. 303, pp. 16-17.

${ }^{322}$ KNIJNIK, Danilo, Os Standards do Convencimento Judicial: Paradigmas para o seu possível controle in Revista da Pós-Graduação da Faculdade de Direito da Universidade de São Paulo, v.3, n. 25, 2001, pp. 111-120.

${ }^{323}$ BADARÓ, Gustavo Henrique Righi Ivahy, Direito ao julgamento por juiz imparcial: como assegurar a imparcialidade objetiva do juiz nos sistemas em que não há juiz de garantias, cit. n. 231, p. 353.
} 
ocorrência de um fato depende de uma altíssima probabilidade de esse fato ter ocorrido. ${ }^{324}$ Existem outros modelos ${ }^{325}$, mas esses são os mais comumente mencionados.

Em alguns países, a utilização dos modelos de constatação é mais comum. Na Alemanha, o modelo de constatação adotado é, em regra, semelhante ao da "reasonable doubt". 326 Existem, no entanto exceções. Na jurisdição trabalhista, caso a prova das alegações seja difícil em virtude da $2^{a}$ Guerra Mundial, o modelo de constatação exige verossimilhança preponderante das alegações; ${ }^{327}$ o mesmo ocorre para a prova do nexo causal nos tribunais sociais. ${ }^{328} \mathrm{Na}$ Suécia o modelo de constatação varia de caso para caso e a utilização dos modelos de constatação é tão disseminada que até mesmo a lei fixa os graus de verossimilhança - expressos em probabilidades numéricas — necessários para as provas de algumas alegações. ${ }^{329}$

Combinando-se o modelo de constatação com o ônus da prova é possível construir todo o cenário fático pertinente ao caso. Assim, para que o juiz possa considerar que um fato ocorreu em um processo ele deve levar em conta quem tinha o ônus de provar esse fato e qual o modelo de constatação utilizado no caso. Se a probabilidade de ocorrência do fato for inferior àquela exigida pelo modelo de constatação, o juiz deve considerar o fato como não ocorrido, uma vez que a parte a quem cabia provar o fato não se desincumbiu de seu ônus, aplicando a regra de julgamento correspondente ao ônus da prova. Se, no entanto, a probabilidade de ocorrência do fato for igual ou superior àquela exigida pelo modelo de constatação, o juiz deve considerar o fato como ocorrido, uma vez que a parte a quem cabia provar o fato se desincumbiu de seu ônus.

\footnotetext{
${ }^{324}$ KNIJNIK propõe um quarto modelo, a ser aplicado especificamente para ser possível a condenação penal com base exclusivamente em prova indicária, segundo o qual deveria haver exclusão razoável de qualquer hipótese que não a de culpa, conforme A prova nos juízos cível, penal e tributário, cit. n. 303, pp. 41-45.

${ }^{325}$ Para uma exposição bastante completa, ver KNIJNIK, Danilo, Os Standards do Convencimento Judicial: Paradigmas para o seu possível controle cit. n. 322, pp. 128-139.

326 WALTER, Gerhard, La libre apreciación de la prueba (investigación acerca del significado, las condiciones y límites del libre convencimiento judicial), trad. Banzhaf, Tomás, Bogotá, Temis, 1985, p. 123, apud POZZA, Pedro Luiz, Sistemas de valoração da prova, cit. n. 279, p. 240.

327 WALTER, Gerhard, La libre apreciación de la prueba (investigación acerca del significado, las condiciones y límites del libre convencimiento judicial), trad. Banzhaf, Tomás, Bogotá, Temis, 1985, pp. 146-147, apud PozZA, Pedro Luiz, Sistemas de valoração da prova, cit. n. 279, p. 240.

${ }^{328}$ WALTER, Gerhard, La libre apreciación de la prueba (investigación acerca del significado, las condiciones y límites del libre convencimiento judicial), trad. Banzhaf, Tomás, Bogotá, Temis, 1985, p. 147, apud PoZZA, Pedro Luiz, Sistemas de valoração da prova, cit. n. 279, p. 240.

${ }^{329}$ PozZA, Pedro Luiz, Sistemas de valoração da prova, cit. n. 279, p. 242.
} 
Como se disse, os modelos de constatação delimitam contextos comunicativos abertos, motivo pelo qual a combinação de modelos de constatação e ônus da prova não determina de maneira inescapável a solução para a determinação dos fatos no caso. O que é possível, sim, é o controle intersubjetivo do discurso justificativo quanto à determinação dos fatos com fundamento na possibilidade comunicativa aberta pelos modelos de constatação.

\subsubsection{Valoração dos indícios}

A doutrina costuma classificar a prova "lato sensu" (no sentido de elemento de prova) em prova direta ou representativa; e prova indireta ${ }^{330}$ ou crítica, ${ }^{331}$ espécie na qual se incluem os indícios ${ }^{332}$. O critério para essa classificação é a necessidade ou não de se utilizar mais de uma inferência ${ }^{333}$ para de um fato conhecido chegar a outro, desconhecido. ${ }^{334}$

Ao firmar a distinção entre prova direta e indireta com base na necessidade ou não de utilização de mais de uma inferência surge a necessidade de conceituar, de maneira preliminar, o processo por meio do qual se chega do fato indiciante à conclusão indiciária. Em um primeiro momento, o fato indiciante deve ser transportado ao processo mediante qualquer meio de prova. Esse transporte constitui a primeira inferência por meio da qual o meio de prova está sujeito à valoração do juiz quanto à credibilidade, de maneira a influir no grau de certeza que é capaz de provocar no juiz quanto à ocorrência do próprio fato indiciante. Essa primeira inferência ocorre também na prova representativa. ${ }^{335}$

A segunda inferência ${ }^{336}$ é o silogismo no qual o fato indiciante transportado para o processo figura como premissa menor, a máxima de experiência "lato sensu" figura como premissa maior ${ }^{337}$ e a conclusão indiciária figura como conclusão, prova do fato a provar.

\footnotetext{
${ }^{330}$ MARQUES, José Frederico, Elementos de direito processual penal, v. 2, Campinas, Millennium, 2009, pp. 371-372.

${ }^{331}$ SCAPINI, Nevio, La prova per indizi nel vigente sistema del processo penale, Milano, Giuffrè, 2001, p. 11.

${ }_{332}$ GOMES FILHO, Antonio Magalhães, A motivação das decisões penais, cit. n. 24, p. 167.

${ }^{333}$ Para alguns autores, só são aceitas duas inferências. V. infra item 2.3.1.6.

${ }^{334}$ GOMES FILHO, Antonio Magalhães, Notas sobre a terminologia da prova (reflexos no processo penal brasileiro), cit. n. 261, p. 310; TONINI, Paolo, La prova penale, cit. n. 261, pp. 32-33; BATTAGLIO, Silvia, Indizio e prova indiziaria nel processo penale in Rivista italiana di diritto e procedura penale, Milano, Giuffrè, 1995, pp. 395-396; KNIJNIK, Danilo, A prova nos juízos cível, penal e tributário, cit. n. 303, p. 28.

${ }^{335}$ KNIJNIK, Danilo, A prova nos juízos cível, penal e tributário, cit. n. 303, p. 26.

${ }^{336} \mathrm{E}$, para os que as aceitam, também as inferências subsequentes.

${ }^{337}$ KNIJNIK, Danilo, A prova nos juízos cível, penal e tributário, cit. n. 303, p. 69.
} 
A máxima da experiência é entendida como um juízo hipotético de conteúdo geral e abstrato, ${ }^{338}$ que expressa o que sói ocorrer em determinadas circunstâncias. ${ }^{339}$ Esse conceito, extremamente amplo, é um gênero, referido neste trabalho como máxima da experiência "lato sensu", composto por duas espécies, as máximas da experiência "stricto sensu" e as regras científicas, ${ }^{340}$ que podem ser aplicadas diretamente pelo juiz se forem do conhecimento do homem médio. ${ }^{341}$

Os critérios de distinção entre essas duas espécies são os seguintes: as regras científicas não admitem exceções, podem ser reconduzidas a experiências mensuráveis e sua validade é passível de verificação, ao passo que as máximas da experiência "stricto sensu" admitem exceções, não podem ser reconduzidas a experiências mensuráveis e sua validade científica não é passível de verificação. ${ }^{342}$ Essa distinção justifica-se, pois conduz a distinções úteis na utilização das circunstâncias indiciantes no processo.

A discussão quanto à possibilidade de utilização do "indício mediato" - assim entendido como o indício que toma como premissa menor a conclusão de outra inferência indiciária bem como a discussão quanto à (in)suficiência do indício isolado para conduzir à certeza judicial $^{343}$ passam pela possibilidade de a inferência indiciária permitir chegar-se à certeza judicial. Nesse ponto, é necessário conceituar que mesmo a certeza judicial é probabilística. $^{344}$

\footnotetext{
${ }^{338}$ STEIN, Friedrich, Das private Wissen des Richters, Leipzig, 1893, p.21 apud ToNINI, Paolo, La prova penale, cit. $n .261$, p. 35 .

${ }^{339}$ TONINI, Paolo, La prova penale, cit. n. 261, p. 35.

${ }^{340}$ SCAPINI, Nevio, La prova per indizi nel vigente sistema del processo penale, cit. $n$. 331, pp. 248-249; TORNAGHI, Hélio, Curso de direito processual penal, v. 1. São Paulo, Saraiva, 1980, p. 455; DöHRING, Erich, Die erporschung des sachverhalts im prozess - beweiserhebung und beweiswürdigung, Berlin, Duncker \& Huimblot, 1964, trad. esp. de Banhaf, Tomás A., La investigación del estado de los hechos en el proceso - la prueba su práctica y apreciación, Buenos Aires, EJEA, 1972, pp. 333-334.

${ }^{341}$ GreCo FILHO, Vicente, Manual de processo penal, $7^{\mathrm{a}}$ ed., São Paulo, Saraiva, 2009, p. 199; ToNINI, Paolo, La prova penale, cit. n. 261, p. 38.

${ }^{342}$ TonINI, Paolo, La prova penale, cit. $n$. 261, pp. 38-39.

${ }^{343}$ Quando se diz certeza judicial deve-se ler "atendimento ao modelo de constatação do "proof beyond reasonable doubt'".

${ }^{344}$ MouRA, Maria Theresa Rocha de Assis, A prova por indícios no processo penal, São Paulo, Saraiva, 1994, p. 1; KNIJNIK, Danilo, A prova nos juízos cível, penal e tributário, cit. n. 303, p. 26; РітомBO, Sérgio Marco Moraes de, Pronúncia e o in dubio pro societate in Boletim do Instituto Manoel Pedro Pimentel, v. 15, n. 17, São Paulo, Centro de Estudos Penais e Criminológicos, 2001, p. 6; CARnelutTi, Francesco, Lezioni sul processo penale, Roma, Ateneo, 1946, pp. 204-205.
} 
A possibilidade de chegar-se à certeza judicial por meio da inferência indiciária - e, mediatamente, por meio da máxima da experiência "lato sensu", em geral é negada, ${ }^{345}$ havendo, no entanto, quem admita essa possibilidade em situações excepcionais. ${ }^{346} \mathrm{~A}$ possibilidade de chegar-se a certeza judicial por meio de inferência indiciária é mais bem avaliada com base na distinção proposta entre máximas da experiência "stricto sensu" e regras científicas.

Assim, é muito mais provável chegar-se à certeza judicial por meio de inferência indiciária quando essa inferência tiver como premissa maior uma regra científica. Isso porque a certeza judicial é uma certeza que está condicionada ao atingimento de um modelo de constatação que pode ser, no caso do juízo penal, por exemplo, bastante elevado. Ora, as regras científicas, em virtude de não admitirem exceções, multiplicam a probabilidade de ocorrência de um fato por 1 (um, ou seja, 100\%). Diferentemente, as máximas da experiência "stricto sensu", por admitirem exceções, multiplicam essa probabilidade por número menor que 1 (um) um, reduzindo, portanto a probabilidade de ocorrência do fato o que, no mais das vezes, afasta a certeza judicial.

Note-se que não é porque uma conclusão indiciária toma como premissa maior uma regra científica, que essa conclusão levará à verdade real, à chance de $100 \%$ de determinado fato ter ocorrido. Isso porque, como acima exposto, a inferência indiciária divide-se em duas outras inferências e a máxima da experiência "lato sensu" só é aplicada na segunda inferência. Quanto ao resultado da primeira inferência, que transporta o fato indiciante para o processo, nenhum meio de prova oferece conclusões absolutamente certas.

\subsection{Qual espécie de inferência?}

A investigação quanto à estrutura do raciocínio indiciário passa pela principal crítica que se faz à redação do atual artigo $239^{347}$ do Código de Processo Penal. Esse dispositivo diz que a segunda inferência do raciocínio por meio do qual do fato indiciante chega-se à conclusão indiciária é uma indução.

\footnotetext{
${ }^{345}$ TONINI, Paolo, La prova penale, cit. n. 261; MoURA, Maria Theresa Rocha de Assis, A prova por indícios no processo penal, cit. $n .344$, pp. 37-38.

346 Battaglio, Silvia, Indizio e prova indiziaria nel processo penale in Rivista italiana di diritto $e$ procedura penale, Milano, Giuffrè, 1995, pp. 398, 401.

347 "Considera-se indício a circunstância conhecida e provada, que, tendo relação com o fato, autorize, por indução, concluir-se a existência de outra ou outras circunstâncias”.
} 
Existe quem concorde com essa redação ${ }^{348}$ e quem diga que, na verdade esse raciocínio é abdutivo, ou seja, aquele que extrai a causa do resultado e da regra de causalidade. ${ }^{349}$ Existe ainda posição segundo a qual o raciocínio inferencial que permite que do fato indiciante prove-se um fato no processo é uma inferência analógica, composta por um raciocínio indutivo (do fato indiciante à regra geral) e um raciocínio dedutivo (da regra geral à conclusão). ${ }^{350}$

Em regra, as máximas da experiência "lato sensu", são obtidas através de indução, ${ }^{351}$ pois partem da observação de fatos para deles extrair uma regra descritiva de uma determinada situação, que associa a ocorrência de dois fatos, num típico raciocínio indutivo, que parte do particular para o geral. Nem sempre isso ocorre, no entanto, nomeadamente quanto às regras científicas. Embora existam regras científicas baseadas na observação e no método da tentativa e erro, é fato que precisam ser confirmadas por meio de raciocínios abstratos, ${ }^{352}$ fundados na coerência linguística ${ }^{353}$ de determinado campo do conhecimento.

Quanto ao silogismo que tem o fato indiciante como premissa menor e a máxima da experiência "lato sensu" como premissa maior, trata-se claramente de inferência dedutiva, que parte do geral (máxima da experiência) para chegar ao particular (resultado da prova indiciária). ${ }^{354}$ Assim, a redação do atual artigo 239 erra ao dizer que o raciocínio indiciário é indutivo, vez que é sempre dedutivo quanto a esse silogismo que, por isso, será a partir desse ponto, referido no trabalho como dedução indiciária. Ademais, por vezes, quando o fato indiciante contribui para a formação da máxima da experiência "stricto sensu" o raciocínio é indutivo-dedutivo ou analógico.

\footnotetext{
${ }^{348}$ SCAPINI, Nevio, La prova per indizi nel vigente sistema del processo penale, cit. n. 331, pp. 6-7.

${ }^{349}$ BATTAGLIO, Silvia, Indizio e prova indiziaria nel processo penale, cit. $n .346, \mathrm{pp} .400-401$.

${ }^{350}$ MourA, Maria Theresa Rocha de Assis, A prova por indícios no processo penal, cit. $n$. 344 , pp. 36-38.

${ }^{351}$ ToRNAGHI, Hélio, Curso de direito processual penal, v. 1 , cit. $n$. 340, pp 454-455; GRECO FILHO, Vicente, Manual de processo penal, cit. $n$. 341, pp. 197, 200.

352 e.g. cálculos matemáticos.

${ }^{353}$ No sentido que WITTGENSTEIN dá ao termo em Philosophical investigations, Hoboken, Blackwell, 1953, trad. port. de Bruni, José Carlos, Investigações filosóficas, São Paulo, Nova Cultural, 1999.

${ }^{354}$ TORNAGHI, Hélio, Curso de direito processual penal, v. 1, cit. n. 340, p. 454; GrECO FILHO, Vicente, Manual de processo penal, cit. n. 341, pp. 197, 200.
} 


\subsection{Características e requisitos dos indícios}

Superada a discussão quanto à espécie de inferência no raciocínio indiciário, fundada na redação do atual artigo 239 do Código de Processo Penal, passa-se à discussão quanto às características e requisitos dos indícios. Esta discussão se funda, na Itália, na redação do artigo 192, $\S 2^{\text {o }}{ }^{355}$ do Código de Processo Penal italiano, fonte de inspiração para o legislador nacional, que propôs redação idêntica ao artigo $168, \S 1^{\text {o }}{ }^{356}$ do Projeto de Código de Processo Penal. Essa discussão se dá em quatro frentes diversas.

A primeira frente de discussão diz respeito à suficiência da redação do referido dispositivo. A segunda frente de discussão diz respeito à caracterização dos requisitos de gravidade, precisão e certeza previstos pela lei e à interação desses requisitos. A terceira frente de discussão, diz respeito à admissibilidade do "indício mediato" e da prova de fato por meio de um só indício. Finalmente, a quarta frente de discussão diz respeito ao valor probante dos indícios.

\subsection{Fato indiciante como fato certo}

Critica-se a redação do artigo 192, $\S 2^{\circ}$ do Código de Processo Penal italiano por não se referir à necessidade de o fato indiciante ser certo, ${ }^{357}$ no sentido de sua existência objetiva ser demonstrada judicialmente através da primeira inferência que compõe o raciocínio indiciário. ${ }^{358}$ Quanto a esse ponto, vale notar que o artigo 239 do Código de Processo Penal refere-se expressamente à necessidade de o raciocínio indiciário fundar-se em fato conhecido e provado.

No mais, é criticável ou, ao menos, carece de precisão a exigência de que a existência objetiva do fato indiciante tenha de ser demonstrada judicialmente. Isso porque a demonstração judicial da existência objetiva de um fato corresponde à descoberta da verdade real, o que não é possível através do processo, que permite que se atinja tão

\footnotetext{
355 "L'esistenza di um fato non può essere desunta da indizi a meno che questi siano gravi, precisi e concordante".

356 "A existência de um fato não pode ser inferida de indícios, salvo quando forem graves, precisos e concordantes".

${ }^{357}$ BATTAGLIO, Silvia, Indizio e prova indiziaria nel processo penale, cit. n. 346, pp. 408-409; KNIJNIK, Danilo, A prova nos juízos cível, penal e tributário, cit. n. 303, pp. 57-59; DöHRING, Erich, Die erporschung des sachverhalts im prozess - beweiserhebung und beweiswürdigung, cit. n. 340, pp. 321-322.

${ }^{358}$ SCAPINI, Nevio, La prova per indizi nel vigente sistema del processo penale, cit. $n$. 331, p. 116.
} 
somente uma verdade subjetiva. A verdade real é impossível de ser obtida através do processo pelo simples fato de que o juiz não presencia os fatos que compõem o substrato sobre o qual se funda o processo.

Nesse ponto, também elogiável a redação do artigo 239 do Código de Processo Penal ao referir-se a fato provado, já que fato provado não é aquele cuja existência é demonstrada objetivamente no processo, mas aquele cuja existência é objeto de certeza judicial. Quanto à exigência de que o fato seja certo ou provado, não há como descartá-la vez que, sendo a certeza judicial probabilística, é necessária que a dedução indiciária funde-se sobre premissa menor cuja ocorrência seja altamente provável, sob pena de o resultado dessa dedução não ser suficientemente provável de modo a fundar certeza judicial.

\subsection{Conceituação da gravidade, precisão e concordância}

A exigência de que os indícios sejam graves, precisos e concordantes, ao contrário do que se afirma, não implica um retorno ao sistema da prova legal. Impõe apenas mais uma “ilha” de valoração legal da prova, ${ }^{359}$ com o fim de afastar o arbítrio ${ }^{360}$ e facilitar o processo decisório. Isso porque esses requisitos decorrem da própria natureza lógica dos indícios $^{361}$ e são características dos indícios como resultado de prova. ${ }^{362}$

Nesse ponto vale salientar que não pode ser confundido o indício como resultado de prova com o resultado de uma inferência estruturalmente igual mas que, exatamente por carecer das características de gravidade, precisão e concordância, não tem o condão de provar processualmente algo, de provocar certeza judicial.

Partindo da premissa de que gravidade, precisão e concordância são características dos indícios, passamos a conceituar esses requisitos de maneira que sejam necessários e suficientes à descrição do indício como processo lógico de demonstração processual de um

\footnotetext{
${ }^{359}$ Idem, pp. 265-267.

${ }^{360}$ BATTAGLIO, Silvia, Indizio e prova indiziaria nel processo penale in Rivista italiana di diritto $e$ procedura penale, Milano, Giuffrè, 1995, p. 404; SCAPINI, Nevio, La prova per indizi nel vigente sistema del processo penale, cit. n. 331, pp. 99-100, 236, 265, n. 92; MARQUES, José Frederico, Elementos de direito processual penal, cit. n. 330, p. 374.

${ }^{361}$ SCAPINI, Nevio, La prova per indizi nel vigente sistema del processo penale, cit. $n .331$, p. 267.

${ }^{362}$ SCAPINI, Nevio, La prova per indizi nel vigente sistema del processo penale, cit. n. 331, pp. 107, 128; BATTAGLIO, Silvia, Indizio e prova indiziaria nel processo penale in Rivista italiana di diritto e procedura penale, Milano, Giuffrè, 1995, p. 405.
} 
fato, ou seja, de maneira que esses requisitos sejam capazes de provocar a certeza judicial, demonstrando a alta probabilidade de ocorrência de um fato.

A gravidade é definida como a confiabilidade das máximas da experiência de modo que dela não possam se extrair muitas conclusões; ${ }^{363}$ como a resistência da conclusão a objeções; ${ }^{364}$ e como pertinência ao "thema probandum". ${ }^{365}$ A precisão é definida como a univocidade de conclusão(ões) extraída(s) das máximas da experiência, ${ }^{366}$ entendida como a possibilidade de justificar racionalmente a escolha pela conclusão mais provável; ${ }^{367}$ como a improbabilidade de ocorrência de outros fatos indicados pela máxima da experiência, ${ }^{368}$ que depende da segurança, validez e logicidade da regra de experiência utilizada. ${ }^{369}$ A concordância é definida como a univocidade entre as conclusões indiciárias, ${ }^{370}$ assim entendida como a concordância horizontal, ou seja, entre conclusões extraídas de fatos indiciantes distintos e não vertical, ou seja, entre conclusões logicamente concatenadas no indício mediato. ${ }^{371}$

Com base na premissa já estabelecida de que os requisitos previstos no artigo $168, \S 1^{\circ}$ do Código de Processo Penal são e devem ser interpretados como características lógicas dos indícios como resultado de prova, capaz de provocar a certeza judicial, esses requisitos devem ser interpretados de maneira que aumentem a probabilidade de ocorrência do fato. Assim, a gravidade deve ser interpretada como adequação do fato indiciante, premissa menor, à máxima da experiência "lato sensu", premissa maior, de modo a limitar a probabilidade e o número de conclusões contrárias à que se pretende chegar; a precisão

\footnotetext{
${ }^{363}$ Gomes FILHO, Antonio Magalhães, Breves anotações sobre a temática das provas no projeto de Código de Processo Penal (Projeto $n^{o} 156 / 2009$ do Senado Federal) in Revista do Advogado 113/2011, p. 41; SCAPINI, Nevio, La prova per indizi nel vigente sistema del processo penale, cit. $n .331, \mathrm{p} .130$

364 TONINI, Paolo, La prova penale, cit. n. 261, p. 40.

${ }^{365}$ BATTAGLIO, Silvia, Indizio e prova indiziaria nel processo penale, cit. n. 346, pp. 412-413.

${ }^{366}$ BATTAGLIO, Silvia, Indizio e prova indiziaria nel processo penale, cit. n. 346, pp. 413-414; GOMES FILHO, Antonio Magalhães, Breves anotações sobre a temática das provas no projeto de Código de Processo Penal (Projeto $n^{o}$ 156/2009 do Senado Federal), cit. n. 363, p. 41; TONINI, Paolo, La prova penale, cit. $n$. 261, p. 40.

${ }^{367}$ BATtAGLIO, Silvia, Indizio e prova indiziaria nel processo penale, cit. n. 346, p. 415; DöHRING, Erich, Die erporschung des sachverhalts im prozess - beweiserhebung und beweiswürdigung, cit. n. 340, p. 337.

${ }^{368}$ SCAPINI, Nevio, La prova per indizi nel vigente sistema del processo penale, cit. $n .331$, p. 117.

${ }^{369}$ Idem, p. 130.

${ }^{370}$ GOMES FILHO, Antonio Magalhães, Breves anotações sobre a temática das provas no projeto de Código de Processo Penal (Projeto $n^{o}$ 156/2009 do Senado Federal), cit.n. 363, p. 41; TONINI, Paolo, La prova penale, cit. $n .261$, p. 40; SCAPINI, Nevio, La prova per indizi nel vigente sistema del processo penale, cit. n. 331, p. 130; BATTAGLIO, Silvia, Indizio e prova indiziaria nel processo penale, cit. n. 346, p. 419.

${ }^{371}$ BAttaglio, Silvia, Indizio e prova indiziaria nel processo penale in Rivista italiana di diritto $e$ procedura penale, Milano, Giuffrè, 1995, pp. 419-420; MouRA, Maria Theresa Rocha de Assis, A prova por indícios no processo penal, cit. $n .344$, pp. 89-90.
} 
deve ser interpretada como a possibilidade de justificar racionalmente a escolha pela conclusão mais provável; e a concordância como a univocidade horizontal entre as conclusões indiciárias.

\subsection{Interação de gravidade, precisão e concordância}

Definidos os conceitos de gravidade, precisão e concordância, ainda é necessário determinar de que maneira esses requisitos interagem. Essa interação também deve resultar das características do indício como processo lógico de demonstração processual de um fato.

TONINI apresenta três teorias sobre a interação desses requisitos. Segundo a primeira tese, todos os indícios devem ser graves, precisos e concordantes. Essa tese é considerada muito rigorosa e apresentada como minoritária. ${ }^{372}$

Segundo a teoria ${ }^{373}$ que prevalece na jurisprudência italiana cada indício deve ser avaliado individualmente quanto à precisão e à gravidade e, depois dessa avaliação individuada, devem ser avaliados em conjunto quanto a sua concordância. ${ }^{374}$ Essa teoria exclui a possibilidade de certeza judicial sobre um fato com base em indício único. ${ }^{375}$

Por fim, uma terceira teoria sustenta que os indícios devem ser avaliados no seu conjunto quanto à gravidade, precisão e concordância. ${ }^{376}$ Dentro dessa teoria ainda distingue-se entre os que acreditam que a concordância entre indícios aumenta a gravidade deles ${ }^{377}$ e os que rejeitam essa ideia. ${ }^{378}$

Deve prevalecer a teoria segundo a qual os indícios devem ser avaliados no seu conjunto quanto à gravidade, precisão e concordância, de modo que a interpretação da lei não

\footnotetext{
${ }^{372}$ TONINI, Paolo, La prova penale, cit. n. 261, p. 41.

${ }^{373}$ Defendida por KNIJNIK em A prova nos juízos cível, penal e tributário, cit. n. 303, pp. 53-57; TORNAGHI, Hélio, Curso de direito processual penal, v. 1, cit. n. 340, p. 458.

${ }^{374}$ TONINI, Paolo, La prova penale, cit. n. 261, p. 41.

${ }^{375}$ KNIJNIK, Danilo, A prova nos juízos cível, penal e tributário, cit. n. 303, p. 51.

376 TONINI, Paolo, La prova penale, cit. n. 261, pp. 42-43.

${ }^{377}$ SCAPINI, Nevio, La prova per indizi nel vigente sistema del processo penale, cit. $n .331$, pp. $255-256$ e n. 51; Moura, Maria Theresa Rocha de Assis, A prova por indícios no processo penal, cit. $n .344$, pp. 90-93, 99; CARNELUTTI, Francesco, Lezioni sul processo penale, cit. n. 344, p. 231.

${ }^{378}$ BatTaglio, Silvia, Indizio e prova indiziaria nel processo penale cit. n. 346, pp. 419-420.
} 
impossibilite ao legislador que decida com fundamento em certeza judicial à qual chegou e que possa justificar racionalmente por meio da fundamentação. Quanto à interação entre a concordância e a gravidade, esta não existe, porque cada raciocínio indiciário subsiste por si mesmo, sendo a concordância capaz de unicamente indicar uma maior probabilidade de ocorrência de um fato com base na univocidade dos resultados de prova de cada indício que, individualmente considerados, continuam produzindo o mesmo nível probabilístico de certeza no julgador.

\subsection{O problema do "indício mediato"}

É posição majoritária dentre a doutrina que fato provado por meio de "indício mediato" não é capaz de gerar certeza judicial, ${ }^{379}$ embora haja quem defenda essa possibilidade ${ }^{380}$ com fundamento no princípio do livre convencimento. ${ }^{381}$ Essa última ideia só poderia ser aceita em situações excepcionalíssimas, nos termos das conclusões do item 4.3.2.1.3..

Entende-se por indício mediato o resultado de prova que se baseia em dupla dedução indiciária, ou seja, aquela que toma como premissa menor um fato indiciante que, por sua vez, é a conclusão indiciária de raciocínio indiciário anterior.

Essa rejeição ao valor probante do "indício mediato" funda-se no seguinte raciocínio: a premissa menor da dedução indiciária deve ser fato certo, pelos motivos expostos no item 4.3.2.4.3; a conclusão indiciária não é fato certo, mas meramente provável; logo, a conclusão indiciária logicamente anterior não pode servir como fato indiciante de raciocínio indiciário (logicamente) posterior.

Ora, embora essa conclusão seja aceitável na maior parte dos casos, nos casos em que a premissa maior da dedução indiciária é regra científica ${ }^{382}$ e a premissa menor seja fato indiciante de cuja ocorrência o julgador tenha certeza probabilística, a conclusão indiciária será fato provado, fato certo, de modo que pode servir como premissa menor para a

\footnotetext{
${ }^{379}$ KNIJNIK, Danilo, A prova nos juízos cível, penal e tributário, cit. n. 303, pp. 59-62; SCAPINI, Nevio, La prova per indizi nel vigente sistema del processo penale, cit. n. 331, p. 117.

${ }^{380}$ DöHRING, Erich, Die erporschung des sachverhalts im prozess - beweiserhebung und beweiswürdigung, cit. n. 340 , p. 322.

${ }^{381}$ BATTAGLIO, Silvia, Indizio e prova indiziaria nel processo penale cit. n. 346, pp. 411-412.

382 BATTAGLIO coloca a questão em termos de confiabilidade da máxima da experiência, sem fazer distinção entre máxima de experiência "stricto sensu" e regra científica em Indizio e prova indiziaria nel processo penale cit. n. 346 , p. 397
} 
dedução indiciária logicamente subsequente. ${ }^{383}$ A conclusão é ainda mais válida quando se trata do juízo cível, no qual a probabilidade exigida pelo modelo de constatação é menor.

\subsection{O problema do indício único}

O problema do indício único diz respeito ao debate quanto à possibilidade de se considerar provado um fato com fundamento em um único raciocínio indiciário, em virtude do requisito legal (na Itália e, eventualmente, no Brasil) e, como demonstrado no item 4.3.2.3.4, lógico, de que os indícios sejam concordantes.

Há quem defenda que, em virtude do menor valor persuasivo dos indícios, o requisito da concordância não é eventual, mas necessário e, por isso, a pluralidade de indícios é necessária. ${ }^{384}$ Nesse ponto, vale lembrar que os requisitos dos indícios são considerados requisitos lógicos porque aumentam a probabilidade de ocorrência de um fato e, desse modo, fazem com que o indício seja capaz de provocar certeza judicial.

Em virtude disso, pelos mesmos motivos expostos no item 2.3.1.3, observadas as condições nas quais é possível que o resultado da prova indiciária seja um fato certo, é possível que um indício isolado seja capaz de induzir a certeza judicial. ${ }^{385}$ Existe, no entanto, uma construção mais complexa entre as que defendem a impossibilidade de se considerar provado um fato com fundamento em um único raciocínio indiciário.

Segundo essa construção o artigo 192, tal como redigido, impõe a conclusão de que o requisito da concordância não é eventual, pelo fato de a redação do artigo ser negativa. Isso transforma a impossibilidade de prova de um fato por meio de indícios em regra e a possibilidade em exceção, condicionada à observância dos três requisitos legais. ${ }^{386}$

\footnotetext{
${ }^{383}$ MourA, Maria Theresa Rocha de Assis, A prova por indícios no processo penal, cit. $n$. 344 , pp. 82-83, 86.

${ }^{384}$ GoMes FILHO, Antonio Magalhães, Breves anotações sobre a temática das provas no projeto de Código de Processo Penal (Projeto $n^{o}$ 156/2009 do Senado Federal), cit.n. 363, p. 41; TONINI, Paolo, La prova penale, cit. n. 261, p. 39; DÖHRING, Erich, Die erporschung des sachverhalts im prozess - beweiserhebung und beweiswürdigung, cit. n. 140, p. 343.

${ }^{385}$ BATTAGLIO, Silvia, Indizio e prova indiziaria nel processo penale, cit. n. 346, pp. 422-423; CARNELUTTI, Francesco, Lezioni sul processo penale, cit. n. 344, p. 231.

${ }^{386}$ SCAPINI, Nevio, La prova per indizi nel vigente sistema del processo penale, cit. $n .331$, pp. 119-120.
} 
Embora a construção seja incontestável, semanticamente falando, a conclusão de que não é possível provar um fato com fundamento em um único raciocínio indiciário, mesmo que, logicamente, esse raciocínio seja capaz de fornecer ao julgador o grau máximo de certeza probabilística ao qual é possível chegar, tem uma consequência grave. Essa consequência é a possibilidade de ocorrência de erro judiciário, pois a rejeição abstrata da possibilidade de se considerar provado um fato com fundamento em um único raciocínio indiciário impede que seja proferida decisão com base na verdade subjetiva atingida no processo. Desse modo, seria salutar se o legislador pátrio modificasse o artigo $168, \S 1^{\circ}$ do Projeto de Código de Processo Penal de modo que sua redação fosse positiva e não negativa.

\subsection{Conclusão parcial}

Abstratamente falando, é possível, por meio de indícios, atingir um grau de probabilidade de ocorrência de um fato suficiente até para tomar decisões que exijam o atendimento do mais alto modelo de constatação. Ocorre, no entanto, que a estrutura lógica do raciocínio indiciário, por meio do qual de um fato levado aos autos o juiz pode considerar ocorrido um fato mencionado pelas partes, impõe ao juiz a observância de uma série de requisitos.

A observância desses requisitos, por sua vez, deve ser mencionada na motivação, a fim de que ela cumpra sua função de demonstrar que a decisão foi tomada de maneira racional. Isso vale tanto para a sentença civil quanto para a sentença penal, com a ressalva de que o juiz cível pode considerar como ocorrido um fato com base em raciocínio indiciário que ofereça uma probabilidade de ocorrência do fato menor do que aquela necessária para a tomada de decisão pelo juiz penal. A diferença, vale repetir, justifica-se pela utilização de diferentes modelos de constatação no juízo cível o no juízo penal.

\subsubsection{Valoração da "nova” prova pericial}

A evolução das ciências nas últimas décadas permitiu que, em determinadas áreas do conhecimento, a prova pericial realizada oferecesse como resultado uma probabilidade tamanha de ocorrência de um fato ${ }^{387}$ que chega a se questionar se o juiz poderia decidir

\footnotetext{
387 SALles, Carlos Alberto de, Transição paradigmática na prova processual civil, in Direito Civil e Processo: estudos em homenagem ao Professor Arruda Alvim, São Paulo, RT, 2007, pp. 911-912.
} 
contra os resultados da perícia científica. ${ }^{388} \mathrm{O}$ caso paradigmático aqui é o do exame de DNA para determinar a ascendência genética de uma pessoa, ${ }^{389}$ uma vez que os resultados desse exame oferecem uma probabilidade de relação de ascendência genética superior a $99,99 \% .{ }^{390}$ É com base no exame de DNA que algumas das - não todas as - reflexões deste capítulo serão feitas, embora as conclusões sejam aplicáveis a qualquer prova pericial cujos resultados oferecem elevado grau de certeza de ocorrência de um fato.

Essa proximidade da certeza que a prova científica tem a capacidade de oferecer em determinados casos influencia o julgador. Isso é demonstrado pelo fato de que, mesmo prevalecendo na jurisprudência a visão segundo a qual o princípio do livre convencimento sempre se sobrepõe às regras de valoração legal da prova, ainda assim a jurisprudência tende a reconhecer que devem ser aplicadas as regras que dispõem de antemão sobre admissibilidade da prova pericial. Assim, tanto o artigo 145, caput, ${ }^{391}$ quanto o artigo 335, ${ }^{392}$ ambos do Código de Processo Civil preveem casos nos quais o juiz deve determinar a produção de prova pericial, mesmo que sua convicção íntima indique a dispensa da prova. Nesses casos, em sentido contrário à jurisprudência que entende pela prevalência do livre convencimento motivado, a maioria ${ }^{393}$ da jurisprudência ${ }^{394}$ entende pela imposição legal da admissibilidade da produção da prova científica.

\footnotetext{
${ }^{388}$ DALBIGNAT-DEHARO, Gaëlle, Verité scientifique et verité judiciaire en droit privé, cit. $n .306$, pp. 32,80 ; LECLERC, Olivier, Le juge et l'expert: contribution à l'étude des rapports entre le droit et la science, cit. n. 169, pp. 75-76;.

${ }^{389}$ LECLERC, Olivier, Le juge et l'expert: contribution à l'étude des rapports entre le droit et la science, cit. n. 169, p. 115.

${ }^{390}$ CÂMARA, Alexandre Freitas, A valoração da prova genética: está o juiz vinculado ao resultado do exame de ADN?, cit. n. 288, pp. 11-13; LACERDA, Maria Francisca dos Santos e ZAGANELLI, Margareth Vetis, Livre apreciação da prova, ciência e raciocínio judicial: considerações sobre a 'cientifização' da prova no processo, cit. n. 69, p.172; LECLERC, Olivier, Le juge et l'expert: contribution à l'étude des rapports entre le droit et la science, cit. n. 169, p. 116.

391 "Quando a prova do fato depender de conhecimento técnico ou científico, o juiz será assistido por perito, segundo o disposto no art. 421".

392 "Em falta de normas jurídicas particulares, o juiz aplicará as regras de experiência comum subministradas pela observação do que ordinariamente acontece e ainda as regras da experiência técnica, ressalvado, quanto a esta, o exame pericial".

${ }^{393}$ Todos do STJ: $3^{\text {a }}$ Turma, REsp n. 957347, rel. Min. NANCY ANDRIGHI, j. 22.3.2010, DJ 28.4.2010; $2^{\mathrm{a}}$ Turma, REsp n. 877541, rel. Min. Eliana CALMON, j. 23.4.2009, DJ 19.5.2009; $1^{\text {a }}$ Turma, RMS n. 20048, rel. Min. JoSÉ Delgado, j. 1.9.2005, DJ 26.9.2005; $3^{\mathrm{a}}$ Turma, REsp n. 317119, rel. Min. ANTÔNIO DE PÁDUA RIBEIRO, j. 4.11.2004, DJ 3.10.2005; $1^{\text {a }}$ Turma REsp n. 750988, rel. Min. LuIZ FuX, j. 17.8.2006, DJ 25.9.2006; $1^{\mathrm{a}}$ Turma, REsp n. 40796, rel. Min. Milton LuIZ PEREIRA, j. 24.10.1994, DJ 28.11.1994; $4^{\mathrm{a}}$ Turma, REsp n. 3003, rel. Min. ATHOS GuSMÃo CARNEIRO, j. 6.8.1991, DJ 9.12.1991.

${ }^{394}$ Em sentido contrário: STJ, $4^{\text {a }}$ Turma, REsp n. 914329, rel. Min. JOÃO OTÁVIO DE NORONHA, j. 4.8.2011, DJ 30.3.2012; STJ, $3^{\text {a }}$ Turma, AgRg no Ag n. 1206781, rel. Min. VASCO Della GiUstina, j. 28.9.2010, DJ 14.10.2010.
} 
Antes, porém, de expor e enfrentar os problemas referentes à "nova",395 prova científica, cabem alguns esclarecimentos para que a discussão leve em conta uma correta concepção da ciência. As considerações que seguem têm como objetivo "tirar a ciência do pedestal", a fim de que se possa discutir sobre ciência e não sobre a quase-religião a qual alguns equiparam a ciência.

Em primeiro lugar, cabe salientar que nenhuma ${ }^{396}$ perícia científica ${ }^{397}$ será capaz de oferecer resultados com $100 \%$ de certeza. ${ }^{398}$ Pelo contrário, a falibilidade da ciência é exatamente um dos requisitos necessários para que uma ciência possa ser caracterizada como tal. ${ }^{399}$ Isso porque a falibilidade permite a verificação e só é ciência o que puder ser reproduzido e verificado.

Em segundo lugar, deve ser descartada a ideia de que o critério de diferenciação entre as "hard sciences" e as "soft sciences" seria a possibilidade de aferição com os sentidos, ${ }^{400}$ só possível nas "hard sciences" 401 — as "soft sciences" seriam, assim, ciências do intelecto. Isso porque a discussão nas "hard sciences" se dá hoje em níveis tais que a experiência sensorial é impossível. Basta pensar nos resultados obtidos em experimentos que utilizam o acelerador de partículas (LHC - "Large Hadron Collider") do CERN ("Centre Européen de Recherche Nucléaire"). Trata-se de colisões entre partículas subatômicas, impossíveis

\footnotetext{
${ }^{395}$ Não tão nova assim. No Canadá já se utiliza o exame de DNA como prova desde 1988, conforme LACERDA, Maria Francisca dos Santos e ZAGANELLI, Margareth Vetis, Livre apreciação da prova, ciência e raciocínio judicial: considerações sobre a 'cientifização' da prova no processo, cit. n. 69, 2009, p. 179.

${ }^{396}$ Exceção feita à matemática, que tem por objetivo exatamente demonstrar a perfeita equivalência $(1=1)$ entre duas coisas, conforme CÂMARA, Alexandre Freitas, A valoração da prova genética: está o juiz vinculado ao resultado do exame de ADN?, cit. $n$. 288, p. 16. A lógica também tem o mesmo objetivo, conforme, Dalbignat-Deharo, Gaëlle, Verité scientifique et verité judiciaire en droit privé, cit. $n$. 306, p. 58 .

${ }^{397}$ Segundo a jurisprudência da Cour de Cassation, o exame de DNA oferece certeza científica, conforme LECLERC, Olivier, Le juge et l'expert: contribution à l'étude des rapports entre le droit et la science, cit. n. 169, p. 117.

398 PozZA, Pedro Luiz, Sistemas de valoração da prova, cit. n. 279, p. 238; LACERDA, Maria Francisca dos Santos e ZAGANELLI, Margareth Vetis, Livre apreciação da prova, ciência e raciocínio judicial: considerações sobre a 'cientifização' da prova no processo, cit.n. 69, pp. 149, 161; GARCIA, André Almeida, Prova Civil, cit. n. 51, p. 61; DaLbignat-Deharo, Gaëlle, Verité scientifique et verité judiciaire en droit privé, cit. $n$. 306, p. 19.

${ }^{399}$ DalBignat-Deharo, Gaëlle, Verité scientifique et verité judiciaire en droit privé, cit. n. 306, pp. 36-37; POPPER, Karl, La logique de la découverte scientifique, pp. 30 e ss. apud LECLERC, Olivier, Le juge et l'expert: contribution à l'étude des rapports entre le droit et la science, cit. $n .169$, pp. 387; LECLERC, Olivier, Le juge et l'expert: contribution à l'étude des rapports entre le droit et la science, cit. n. 169, pp. 118.

${ }^{400}$ LECLERC, Olivier, Le juge et l'expert: contribution à l'étude des rapports entre le droit et la science, cit. n. 169, p. 114.

${ }^{401}$ LACERDA, Maria Francisca dos Santos e ZAGANELLI, Margareth Vetis, Livre apreciação da prova, ciência e raciocínio judicial: considerações sobre a 'cientifização' da prova no processo, cit. n. 69 , pp. 158-164.
} 
de apreensão por qualquer dos sentidos humanos. Assim, mesmo as "hard sciences" são capazes de atingir tamanho grau de abstração que acabam por se aproximar das "soft sciences". Quanto maior o grau de abstração (em qualquer ramo da ciência), mais se afasta da certeza e mais se aproxima da convicção. ${ }^{402}$

Apesar de a ciência e, no que aqui importa, a perícia científica não serem capazes de oferecer mais do que uma convicção, é certo que a convicção que a prova científica é capaz de provocar no juiz é tão grande que o próprio Código de Processo Civil retira do juiz a possibilidade de decidir quanto à admissibilidade da prova científica. ${ }^{403}$ Os artigos 145, caput, 335 e 420, parágrafo único, I, ${ }^{404}$ todos do Código de Processo Civil são expressos ao dispor que a prova pericial é necessária toda vez que determinado conhecimento fugir da esfera do conhecimento privado do juiz. ${ }^{405}$

Assim, levando em conta as conclusões às quais se chegou (supra, 4.3.2.1.3) sobre a vinculação do juiz às normas que regulam de antemão sobre a admissibilidade de um meio de prova cabe perguntar: Existe alguma hipótese na qual o juiz pode decidir contra o resultado de uma prova científica? Em caso positivo, qual(is) é(são) essa(s) hipótese(s)?

\subsection{Valoração da perícia e valoração dos resultados da perícia científica}

Alguns $^{406}$ apontam que o juiz não está, de nenhuma maneira, vinculado aos resultados da perícia; que o livre convencimento racional permite que decida com base em quaisquer outros elementos de prova. E, realmente, é o que se extrai do próprio Código de Processo Civil. ${ }^{407}$ Ocorre que toda vez que se fala em livre convencimento vale lembrar-se do

\footnotetext{
${ }^{402}$ QuINE, Willard Van Orman, The Web of Belief, $2^{\mathrm{a}}$ ed., New York, Random House, 1978, passim.

${ }^{403}$ Na França o juiz pode rejeitar a produção de prova científica caso entenda que não há sequer uma narração minimamente fundamentada em elementos de prova trazidos ao processo indicando a necessidade de produção dessa prova, conforme LECLERC, Olivier, Le juge et l'expert: contribution à l'étude des rapports entre le droit et la science, cit. $n$. 169, pp. 115. Não se abre essa possibilidade quando a questão disser respeito à produção de perícia de DNA para determinar vínculo de ascendência biológica, idem, p. 116. 404 "O juiz indeferirá a perícia quando a prova do fato não depender do conhecimento especial de técnico".

${ }^{405}$ GOMES FILHO, Antonio Magalhães, Provas, cit. n. 98, p. 274. Assim também na França, conforme LECLERC, Olivier, Le juge et l'expert: contribution à l'étude des rapports entre le droit et la science, cit. n. 169, pp. 6-7.

${ }^{406}$ CÂMARA, Alexandre Freitas, $A$ valoração da prova genética: está o juiz vinculado ao resultado do exame de ADN?, cit. n. 288, pp. 18-19; LACERDA, Maria Francisca dos Santos e ZAGANELLI, Margareth Vetis, Livre apreciação da prova, ciência e raciocínio judicial: considerações sobre a 'cientifização' da prova no processo, cit. n. 69, p. 169.

${ }^{407}$ Art. 436: "o juiz não está adstrito ao laudo pericial, podendo formar a sua convicção com outros elementos ou fatos provados nos autos".
} 
adjetivo que acompanha a expressão. Em outras palavras, o convencimento do juiz é livre, mas deve ser racional e essa racionalidade deve transparecer na motivação da decisão.

A motivação, além da importância legitimadora apontada ${ }^{408}$ (supra, 2.3.2), é norma constitucional, ${ }^{409}$ hierarquicamente superior ao princípio do livre convencimento. Há mesmo quem diga que se trata de princípio fundamental. ${ }^{410} \mathrm{~A}$ motivação, assim, se impõe sobre o livre convencimento do juiz, transformando-o no livre convencimento racional.

Com base nesse caráter racional e motivado do convencimento do juiz é possível dizer que, embora o juiz possa, abstratamente, decidir em sentido contrário aos resultados da perícia — ou seja, considerar como não ocorrido um fato que os resultados da perícia disseram ter ocorrido - , a imposição de racionalidade a sua decisão limita muito essa possibilidade, na prática.

É por uma razão que o Código de Processo Civil impõe ao juiz a admissibilidade quanto à realização da prova pericial toda vez que a discussão fugir do âmbito de sua ciência privada: o juiz não tem a formação intelectual necessária para compreender racionalmente o elemento de prova. ${ }^{411} \mathrm{O}$ que se exige do juiz é um conhecimento amplo do Direito. Tão amplo que o sistema jurídico presume que o juiz conheça todo o Direito ("iura novit curia"). Nem o sistema jurídico e tampouco os concursos públicos, no entanto, exigem do juiz conhecimentos técnicos específicos fora do Direito. ${ }^{412}$

\footnotetext{
${ }^{408}$ DalBignAt-Deharo, Gaëlle, Verité scientifique et verité judiciaire en droit privé, cit. $n$. 306, p. 49.

${ }^{409}$ Constituição Federal, artigo 93, IX: "todos os julgamentos dos órgãos do Poder Judiciário serão públicos, e fundamentadas todas as decisões, sob pena de nulidade, podendo a lei limitar a presença, em determinados atos, às próprias partes e a seus advogados, ou somente a estes, em casos nos quais a preservação do direito à intimidade do interessado no sigilo não prejudique o interesse público à informação".

${ }^{410}$ SouZA, Wilson Alves de, Sentença civil imotivada: caracterização da sentença civil imotivada no direito brasileiro, cit. $n .51$, p. 200. Na França, DALBIGNAT-DeHARO, Gaëlle, Verité scientifique et verité judiciaire en droit privé, cit. n. 306, p. 404.

${ }^{411}$ Dalbignat-Deharo, Gaëlle, Verité scientifique et verité judiciaire en droit privé, cit. n. 306, pp. 32-33; LACERDA, Maria Francisca dos Santos e ZAGANELLI, Margareth Vetis, Livre apreciação da prova, ciência e raciocínio judicial: considerações sobre a 'cientifização' da prova no processo, cit. $n .69$, pp. 163-164; GARCIA, André Almeida, Prova Civil, cit. n. 51, p. 59; LECLERC, Olivier, Le juge et l'expert: contribution à l'étude des rapports entre le droit et la science, cit. $n$. 169, pp. 84, 392-393; TARUFFO, Michele, Conoscenza scientifica e decisione giudiziaria: profili generali in Decisione giudiziaria e verità scientifica, Milano, Giuffrè, 2005, p. 22; GARCIA, Francisco de Assis, Da prova pericial no processo civil, cit. n. 288, pp. 221222

${ }^{412}$ LECLERC apresenta uma exceção: no estado norte-americano de Michigan, existe uma corte especializada em conflitos relativos às novas tecnologias da informação, composta por juízes com conhecimento técnico específico, Le juge et l'expert: contribution à l'étude des rapports entre le droit et la science, cit. n. 169, p. 394.
} 
Assim, se o juiz não tem a formação intelectual necessária para apreender diretamente determinados elementos de prova, ${ }^{413}$ como ele poderia motivar racionalmente uma decisão na qual ele rejeita o resultado da prova sobre esses elementos? Sim, é fato que, se a perícia recair sobre elementos de prova cuja apreensão pudesse ser realizada diretamente pelo juiz, ${ }^{414}$ ele pode discordar do resultado da perícia. ${ }^{415}$ No entanto, não é isso que aqui se discute. Aqui se discute se o juiz pode discordar dos resultados da perícia científica de alta complexidade e que oferece elevado grau de probabilidade de ocorrência de um fato. ${ }^{416}$ Nesses casos o juiz não pode, com fundamento unicamente no artigo 436 do Código de Processo Civil, discordar dos resultados da perícia.

É possível apontar outro fundamento para que o juiz possa decidir em sentido contrário ao do resultado de prova trazido ao processo por meio de prova pericial. Trata-se da função do juiz como "peritus peritorum" $" 417$, ou da precedência funcional do juiz sobre o perito, ${ }^{418}$ que é um auxiliar do juízo. Essa precedência é evidente em diversos dispositivos ${ }^{419}$ do Código de Processo Civil.

Assim, o juiz pode, com base nessa precedência, controlar a produção da prova pericial. Essa possibilidade é mais bem estudada no direito norte-americano, no qual a prova pericial é trazida quase ${ }^{420}$ que exclusivamente pelos assistentes técnicos das partes e, em regra, a prova é valorada pelo júri. São esses fatos que fundamentam uma maior preocupação com a admissibilidade da prova pericial, com o objetivo de evitar que os fatos

\footnotetext{
${ }^{413}$ GOMES FILHO, Antonio Magalhães, Provas, cit. n. 98, p. 274.

${ }^{414}$ Fatos compreendidos pela ciência privada do juiz.

${ }^{415}$ Embora, nesses casos, a prova pericial devesse, na realidade, ter sido inadmitida, conforme o artigo 420 , parágrafo único, I, do Código de Processo Civil: "O juiz indeferirá a perícia quando a prova do fato não depender do conhecimento especial de técnico".

${ }^{416}$ O paradigma, como já se disse, é o exame de DNA para determinar a relação de ascendência biológica entre duas pessoas.

${ }^{417}$ TARUFFO, Michele, Conoscenza scientifica e decisione giudiziaria: profili generali cit. n. 411, 2005, p. 22.

${ }^{418}$ LECLERC, Olivier, Le juge et l'expert: contribution à l'étude des rapports entre le droit et la science, cit. $n .169$, p. 51.

${ }^{419}$ Art. $145, \S 3^{\text {o: }}$ "nas localidades onde não houver profissionais qualificados que preencham os requisitos dos parágrafos anteriores, a indicação dos peritos será de livre escolha do juiz"; art. 426: "compete ao juiz: I indeferir quesitos impertinentes; II - formular os que entender necessários ao esclarecimento da causa"; art. 437: “o juiz poderá determinar, de ofício ou a requerimento da parte, a realização de nova perícia, quando a matéria não lhe parecer suficientemente esclarecida".

${ }^{420} \mathrm{O}$ artigo 706 das "Federal Rules of Evidence" permite ao juiz consultar um perito da Corte. Essa possibilidade, no entanto, não é muito utilizada, embora tenha sido em um caso de "mass torts" envolvendo próteses mamárias, LECLERC, Olivier, Le juge et l'expert: contribution à l'étude des rapports entre le droit et la science, cit. n. 169, pp. 396-398.
} 
possam ser considerados ocorridos com base em má ciência ${ }^{421}$ (“junk science”). Atualmente $^{422}$ no direito norte-americano, os critérios jurisprudenciais de admissibilidade da prova pericial são a confirmação por testes - ou pelo menos a possibilidade disso - e a aceitação na comunidade científica, aferida pela revisão pelos pares e pela publicação em publicações especializadas. ${ }^{423}$ As "Federal Rules of Evidence" acrescentam ainda, em seu artigo 702, a exigência de que a perícia seja apta a provar os fatos controversos. ${ }^{424}$

Voltando ao direito brasileiro, verifica-se que os poderes conferidos ao juiz em seu papel de "peritus peritorum" 425 permitem que ele controle mesmo a perícia científica de alta complexidade. Isso não significa, no entanto, que o juiz possa, com base nesses poderes, decidir contra o resultado de prova trazido aos autos por meio de perícia científica de alta complexidade. ${ }^{426} \mathrm{O}$ controle do juiz sobre a perícia como "peritus peritorum" é um controle formal, não um controle material. Ou seja, o juiz pode rejeitar toda a perícia, com base nos mais diversos fundamentos, que podem ser trazidos aos autos por diversos meios de prova. $^{427}$

O que o juiz não pode é rejeitar o resultado de prova trazido por meio da perícia sem que se baseie em outros elementos técnicos trazidos aos autos. Em outras palavras, o juiz só pode rejeitar o resultado de prova trazido aos autos por meio de uma perícia científica se

\footnotetext{
${ }^{421}$ LECLERC, Olivier, Le juge et l'expert: contribution à l'étude des rapports entre le droit et la science, cit. n. 169 , pp. 386, 391.

${ }^{422}$ Para uma exposição da evolução da jurisprudência norte-americana no que se refere aos critérios distintivos entre "junk science" e a verdadeira ciência: MANZANO, Luís Fernando de Moraes, Prova pericial: admissibilidade e assunção da prova científica e técnica no processo brasileiro, São Paulo, Atlas, 2011, pp. 186-212; Dominioni, Oreste, In tema di nuova prova scientifica in Diritto penale e processo, n. 9, Milano, IPSOA, 2001, pp. 1061-1065; LECLERC, Olivier, Le juge et l'expert: contribution à l'étude des rapports entre le droit et la science, cit. n. 169, pp. 373-386.

${ }^{423}$ LECLERC, Olivier, Le juge et l'expert: contribution à l'étude des rapports entre le droit et la science, cit. n. 169, pp. 387-388; LACERDA, Maria Francisca dos Santos e ZAGANELLI, Margareth Vetis, Livre apreciação da prova, ciência e raciocínio judicial: considerações sobre a 'cientifização' da prova no processo, cit. $n .69$, p. 168.

${ }^{424}$ LECLERC, Olivier, Le juge et l'expert: contribution à l'étude des rapports entre le droit et la science, cit. n. 169, pp. 391-392.

${ }^{425}$ Em especial a possibilidade que lhe confere o artigo 437 do Código de Processo Civil.

${ }^{426}$ DALBIGNAT-DEHARO, Gaëlle, Verité scientifique et verité judiciaire en droit privé, cit. n. 306, p. 38.

${ }^{427}$ E.g. o juiz pode determinar a realização de nova perícia caso o presidente da associação de classe à qual o perito está vinculado, em testemunho, declare que o perito é pouquíssimo competente e que não costuma aplicar os métodos corretos na realização de perícia.
} 
fundamentar sua decisão em outra perícia científica ou em pareceres técnicos ${ }^{428}$ submetidos ao contraditório. ${ }^{429}$

\subsection{Objeto da perícia e objeto da prova}

DALBIGNAT-DEHARO afirma que em certas hipóteses o juiz pode deixar de lado o resultado da perícia científica e decidir não com base em um silogismo no qual o resultado da perícia científica determina a premissa menor. A decisão, nessas hipóteses, levaria em conta todos os valores envolvidos — incluindo a verdade - e seria tomada na tentativa de otimizar todos esses valores, ${ }^{430}$ demonstrando argumentativamente ${ }^{431}$ a prevalência de determinados valores. A decisão, assim seria tomada levando em conta não só a verdade estabelecida pela prova científica, mas todas as consequências sociais da decisão que permitem a pacificação social do conflito. O exemplo de decisão que leva em conta outros fatores envolvidos no conflito além da busca da verdade seriam os casos em que o juiz afirma a relação de paternidade entre duas pessoas apesar de o resultado do exame de DNA não ter comprovado a relação de ascendência biológica entre elas. ${ }^{432}$

Esse exemplo, no entanto, não corrobora a afirmação. Isso porque não há causalidade automática entre a relação de ascendência biológica entre duas pessoas e a relação de paternidade entre essas mesmas duas pessoas. Com as mudanças na sociedade, que passou a se organizar em famílias de maneira diferente ${ }^{433}$ daquela maneira como a família comumente sempre se estruturou, o direito também mudou sua concepção sobre o que seja a família. Assim, o critério para que se pudesse falar que havia uma família deixou de ser a consanguinidade - ou, pelo menos, esta deixou de ser o critério exclusivo. O critério foi substituído - ou, pelo menos complementado ${ }^{434}$ — pelo critério da afetividade. Segundo esse critério as relações de parentesco estabelecem-se em virtude dos vínculos afetivos que se formam entre as pessoas e da convivência familiar.

\footnotetext{
${ }^{428}$ Com fundamento no artigo 427, do Código de Processo Civil: “o juiz poderá dispensar prova pericial quando as partes, na inicial e na contestação, apresentarem sobre as questões de fato pareceres técnicos ou documentos elucidativos que considerar suficientes".

${ }^{429}$ Uma vez que é o contraditório que transforma os pareceres técnicos trazidos pelas partes de elementos de convicção em prova.

${ }^{430}$ Verité scientifique et verité judiciaire en droit privé, cit. $n .306$, p. 46.

${ }^{431}$ Idem, p. 60

${ }^{432}$ Idem, p. 81.

${ }^{433}$ E.g. relações homoafetivas, famílias com um só ascendente.

${ }^{434}$ LÔBO, Paulo, Famílias, São Paulo, Saraiva, 2008, pp. 47-52.
} 
Ou seja, adotando-se o critério da afetividade, para que haja a relação de paternidade consequência jurídica - é necessária a prova de que entre duas pessoas estabeleceram-se vínculos afetivos equivalentes aos de uma relação entre um pai e um filho (premissa menor do silogismo). Assim, quando o juiz reconhece a relação de parentesco entre duas pessoas apesar de o exame de DNA ter comprovado não haver relação de ascendência biológica entre essas pessoas, o juiz não forma seu convencimento contra o resultado de prova trazido ao processo por meio da perícia. O que o juiz faz nesse caso é aplicar um critério para determinar a relação de paternidade que não depende da prova da ascendência biológica. $^{435}$

Ou seja, o juiz sequer leva em conta o resultado da perícia científica, o que equivale a dizer que ele não decide contra o resultado da perícia, uma vez que o resultado da perícia não tem o condão de influenciar em nenhum grau sua convicção. O juiz não decide apesar do resultado da perícia, ele decide como se esse resultado não existisse.

Neste caso, portanto, configura-se mais uma hipótese na qual aparentemente, e só aparentemente, o juiz decide contra o resultado de prova trazido ao processo por meio de perícia científica de alta complexidade. O que ocorre, neste caso, é que o objeto da perícia está fora do "thema probandum", uma vez que a norma a ser aplicada pelo juiz é diferente ${ }^{436}$ daquela que seria aplicada caso o objeto da perícia fizesse parte do "thema probandum".

\subsection{Perícia e modelos de constatação}

Os modelos de constatação abrem, portanto, a única possibilidade de o juiz decidir contra o resultado de prova trazido ao processo por meio de perícia técnica. Essa decisão se dá seguindo algumas etapas. Na primeira etapa o juiz decide - motivadamente - qual o modelo de constatação aplicável ao processo que ele tem que decidir. Imagine-se, a título de exemplo que o juiz decide que nesse processo o modelo de constatação é o "beyond reasonable doubt". Na segunda etapa o juiz valora a prova científica - a título de exemplo,

\footnotetext{
${ }^{435}$ Esse exemplo é bastante ilustrativo da relação dialética entre a fixação da norma e a determinação dos fatos, bem como do caráter teleológico da decisão final realizada pelo juiz.

${ }^{436}$ DALBIGNAT-DEHARO, Gaëlle, Verité scientifique et verité judiciaire en droit privé, Paris, LGDJ, 2004, pp. 68-69.
} 
imaginemos que a perícia apontou existir $70 \%$ de probabilidade de que um fato tenha ocorrido e que o juiz equivale essa probabilidade a um grau de convicção inferior ao "beyond reasonable doubt". Na terceira etapa o juiz aplica o modelo de constatação aos resultados da perícia. No caso hipotético apresentado, o juiz pode dizer que a probabilidade de $70 \%$ apontada pela perícia técnica não atinge o grau de convicção exigido pelo modelo de constatação adotado, que é aquele do "beyond reasonable doubt". Assim, embora a perícia científica tenha apontado que existe $70 \%$ de probabilidade de um fato ter ocorrido, o juiz pode dizer que, para a tomada de decisão naquele processo, deve considerar-se que o fato não ocorreu.

A possibilidade que se abre ao juiz nesses casos, por óbvio, impõe-lhe um grande ônus argumentativo. Em primeiro lugar, o juiz deve fundamentar a sua escolha de modelo de constatação. Em segundo lugar, deve fundamentar a valoração que fez sobre os resultados apontados pela perícia científica. Por último, deve fundamentar a sua decisão sobre o atendimento ou não ao modelo de constatação pelos resultados da perícia científica.

\subsection{Conclusão parcial}

Como se viu, a nova prova pericial científica de alta complexidade impõe novos desafios para a tomada de decisão pelo juiz e para a motivação dessa decisão. Ao ter que lidar processualmente com ramos do conhecimento com os quais tem pouco ou nenhuma familiaridade, o juiz deixa de ter o apoio de sua ciência privada. Com isso, limitam-se suas possibilidades de atuar como "peritus peritorum".

Assim, a exemplo do que ocorre com os indícios, características intrínsecas da perícia impõem novas dificuldades e exigências específicas à motivação das decisões judiciais toda vez que se utilize desse meio prova. Isso porque o caráter científico e o grau de certeza oferecido pela "nova" prova pericial limitam as possibilidades de motivação verdadeiramente racional da decisão. 


\section{A MOTIVAÇÃO NA TEORIA dAS NULIDADES dOS ATOS PROCESSUAIS}

Respondida a primeira grande pergunta (“O que é uma decisão motivada?”) que esse trabalho se propôs a responder (de maneira resumida, supra, 3.7.4) e identificados alguns problemas comuns na fundamentação das decisões (supra, Capítulo 4), é necessário responder à segunda pergunta que esse trabalho se propôs a responder: "Quais as consequências de uma decisão imotivada?". Essa pergunta começou a ser respondida no item 2.3.3.

Ficou estabelecido, naquele item, que o dever de fundamentação das decisões judiciais é veiculado por norma que se estrutura sob a forma de regra. Disso decorre que, não sendo a decisão motivada nos termos do item 3.7.4., resulta necessariamente a consequência prevista no art. 93, IX, da Constituição Federal: a nulidade da decisão.

O que significa, no entanto, dizer que a decisão imotivada é nula? Aplicar exatamente a sanção prevista - muitas vezes atecnicamente - pela norma no campo das nulidades, sem levar em conta o caso concreto, não é a melhor solução. ${ }^{437}$ Daí porque se faz necessário recorrer à teoria das nulidades dos atos processuais.

A justificação da superioridade de uma teoria das nulidades sobre as demais ${ }^{438}$ é atividade extremamente complexa, digna de um estudo que se dedique exclusivamente a ela. Por esse motivo, e para não perder o escopo desta dissertação, a adoção da teoria das nulidades processuais de CABRAL é uma premissa que não será discutida. ${ }^{439}$

Assim, neste Capítulo, será apresentada a teoria de CABRAL sobre nulidades processuais (item 5.1) para que seja possível explorar as consequências dessa teoria. Em um primeiro momento, serão analisadas as construções que postulam pela inexistência da motivação em

\footnotetext{
${ }^{437}$ CABRal, Antonio do Passo, Nulidades no processo moderno: contraditório, proteção da confiança e validade prima facie dos atos processuais, cit. $n$. 70, pp. 65-75.

${ }^{438}$ Uma lista, que não pretende ser exaustiva, das teorias das nulidades processuais inclui MAYER, Lucie, Actes du procès et la théoria de l'acte juridique, Paris, IRJS, 2009; CALMON DE PASSOS, José Joaquim, Esboço de uma teoria das nulidades aplicadas às nulidades processuais, Rio de Janeiro, Forense, 2009; WAMBIER, Teresa Arruda Alvim, Nulidades do processo e da sentença, São Paulo, RT, 2004.

${ }^{439}$ Um dos fundamentos da adoção dessa teoria é a importância central que dá ao contraditório, consentânea com a teoria da motivação da decisão judicial exposta neste trabalho.
} 
algumas situações específicas (item 5.2) e, depois, serão exploradas as consequências específicas da adoção dessa teoria das nulidades processuais (item 5.3).

\subsection{Teoria comunicativa das nulidades processuais}

A teoria de CABRAL sobre nulidades processuais parte de duas constatações iniciais. A primeira constatação é a de que não é possível construir uma teoria útil das nulidades fundamentada no que prevê o legislador. Essa teoria tem que ser construída no plano abstrato das ideias para, depois, voltar ao direito positivo. ${ }^{440}$ A segunda constatação é a de que não é possível é possível construir uma teoria útil das nulidades fundamentada no vício do ato. $\mathrm{O}$ fundamento de uma teoria das nulidades deve ser a consequência dos vícios. ${ }^{441}$ Assim, os atos processuais devem ser vistos, quanto à validade, de acordo com sua função teleológica na dinâmica da relação processual.

A partir dessas constatações, são estabelecidas as três premissas da teoria: a concepção do contraditório como influência reflexiva, o procedimento como formalização dessa influência e o aspecto cooperativo do contraditório. O contraditório como direito de influência significa a possibilidade de "condicionar eficazmente a atuação dos demais sujeitos do processo" 442 e divide-se em um direito de expressão e um direito de consideração. Este último é correlato ao dever de atenção imposto ao juiz. ${ }^{443}$

Essa maneira de encarar o contraditório resulta em uma ressignificação da ideia de processo como relação processual ${ }^{444}$ para que esse seja encarado não como um conjunto de relações vetoriais, mas de influências recíprocas. ${ }^{445} \mathrm{O}$ procedimento, nesse conceito ressignificado de processo como relação processual, passa a ser visto como o meio de garantir o funcionamento desse complexo de influências recíprocas. ${ }^{446}$

\footnotetext{
${ }^{440}$ CABRAL, Antonio do Passo, Nulidades no processo moderno: contraditório, proteção da confiança e validade prima facie dos atos processuais, cit. $n$. 70, pp. 67-73.

${ }^{441}$ Idem, pp. 87-88.

442 Idem, p. 112.

${ }^{443}$ Idem, pp. 140-148.

${ }^{444}$ BüLOW, Oskar Von, Die Lehre von Prozesseinreden und die Prozessvoraussetzungen, Aalen, 1969, reed. do original, publicado em Giessen, 1868, apud CABRAL, Antonio do Passo, Nulidades no processo moderno: contraditório, proteção da confiança e validade prima facie dos atos processuais, cit. n. 70, p. 158.

${ }^{445}$ CABRAL, Antonio do Passo, Nulidades no processo moderno: contraditório, proteção da confiança e validade prima facie dos atos processuais, cit. $n$. 70, pp. 158-171.

${ }^{446}$ CABRAL, Antonio do Passo, Nulidades no processo moderno: contraditório, proteção da confiança e validade prima facie dos atos processuais, cit.n. 70, pp.171-173; LUCON, Paulo Henrique dos Santos,
} 
A formalização da influência recíproca dos sujeitos do processo significa o reconhecimento de que são as formas que permitem a efetivação do contraditório como direito de influência. Assim, as formas do processo devem ser respeitadas, na medida e até o limite que sejam capazes de garantir a possibilidade de influência recíproca dos sujeitos processuais. ${ }^{447}$ Nessa perspectiva, o formalismo processual é importante, mas não um fim em si mesmo.

Disso - do fato de o respeito às formas não ser um fim em si mesmo — resulta que todos os atos processuais têm uma validade prima facie, que impõe um ônus argumentativo ${ }^{448}$ quando se quer nulificar o ato. Disso resulta também que a única classificação útil das nulidades processuais é aquela que divide os defeitos em sanáveis e insanáveis. São insanáveis, segundo essa classificação, somente os defeitos formais que repercutam comunicativamente $^{449}$ — isto é, se impedir ou dificultar a demonstração do acerto das alegações pelas partes. ${ }^{450}$

O aspecto cooperativo do contraditório decorre de enxergar os deveres que o contraditório impõe com o objetivo de cumprir sua função de comunicação e influência recíproca dos sujeitos do processo. Dentre esses deveres, destaca-se o dever de colaboração que, somado ao dever de boa-fé no processo, impõe limites ao contraditório para que não se abuse dele. ${ }^{451}$ Isso resulta na necessidade de invalidação dos atos praticados em violação a esses deveres. $^{452}$

Embargos à execução, 2a ed., São Paulo, Saraiva, 2007, p. 87; GoMES FILHO, Antonio Magalhães, A motivação das decisões penais, cit. $n$. 24, pp. 28-29.

${ }_{447}$ CABRAL, Antonio do Passo, Nulidades no processo moderno: contraditório, proteção da confiança e validade prima facie dos atos processuais, cit. $n$. 70, pp. 175-184.

${ }^{448}$ Esse ônus argumentativo chega a abranger a necessidade de justificar a nulificação do ato sob a ótica do conflito entre os princípios do respeito às formas e da economia processual, utilizando po critério da proporcionalidade, conforme CABRAL, Antonio do Passo, Nulidades no processo moderno: contraditório, proteção da confiança e validade prima facie dos atos processuais, cit. $n$. 70, pp. 343-345.

${ }^{449}$ CABRal, Antonio do Passo, Nulidades no processo moderno: contraditório, proteção da confiança e validade prima facie dos atos processuais, cit. n. 70, pp. 185-205.

${ }^{450}$ Idem, pp. 278-279.

${ }^{451}$ A necessidade de evitar que as partes se utilizassem de todos os meios possíveis, mesmo que imorais, no processo já era vislumbrada por MANUEl CARLOS DE FIGUEIREDO FERRAZ, Apontamentos sobre a noção ontológica do processo, São Paulo, Revista dos Tribunais, 1936, pp. 150-151.

${ }^{452}$ CABRAL, Antonio do Passo, Nulidades no processo moderno: contraditório, proteção da confiança e validade prima facie dos atos processuais, cit. n. 70, pp. 207-234. 
Dessas premissas resulta, além das consequências já apresentadas, que a nulificação deve ser imposta se a consequência do ato prejudicar o direito de informação, de consideração ou de reação, de maneira que influencie na decisão final ${ }^{453}$. Tudo isso deve levar em conta o fato de ter havido ou não um juízo de admissibilidade prévio sobre o ato e sua posição na cadeia de influências recíprocas. ${ }^{454}$

\subsection{Hipóteses de inexistência da motivação}

Definidos os contornos da teoria da nulidade dos atos processuais da qual serão extraídas as consequências dos vícios de motivação, é necessário, em um primeiro momento, analisar algumas construções doutrinárias que enxergam na insufiência da motivação uma causa de sua inexistência e de inexistência da própria decisão. TARUFFO, por exemplo, defende que alguns vícios da motivação resultam na inexistência da sentença sob o fundamento de o efeito sanatório da coisa julgada permitir a estabilização de uma decisão que não atende aos requisitos mínimos para que se possa falar em decisão judicial e cujos limites objetivos não podem ser facilmente determinados. ${ }^{455}$

GOMES FILHO, por sua vez, entende que a completa omissão gráfica da motivação é o mais grave dos vícios relacionados à motivação. A inexistência de motivação, no entanto, não se resume a este caso, mas abrange também os casos em que há mera aparência de motivação. Isso ocorre toda vez que o juiz utiliza fórmulas pré-fabricadas, que podem ser afirmações vagas que sirvam a um sem-número de casos ou mesmo tautológicas petições de princípio. $^{456,457}$

Também seria inexistente a motivação que não atenda ao requisito da integridade, ou seja, que não explicite todas as escolhas realizadas no processo de tomada de decisão ou deixe

\footnotetext{
${ }^{453}$ BADARÓ, Gustavo Henrique Righi Ivahy, Vícios de motivação da sentença penal: ausência de motivação, motivação contraditória, motivação implícita e motivação per relationem, cit. $n .21$, p. 123.

${ }^{454}$ CABRAL, Antonio do Passo, Nulidades no processo moderno: contraditório, proteção da confiança e validade prima facie dos atos processuais, cit. $n$. 70, pp. 269-300.

${ }^{455}$ TARUFFO, Michele, La motivazione della sentenza civile, cit. $n$. 1, pp. 462-469. O conteúdo mínimo para que se pudesse considerar existente a motivação corresponderia ao primeiro nível do esquema justificativo apresentado supra 3.6.1.

456 e.g.: "presentes os requisitos do art. 273 do CPC, concedo a liminar"; “ presentes os requisitos do art. 312 do CPP, determino a prisão preventiva".

${ }^{457}$ GOMES FILHO, Antonio Magalhães, A motivação das decisões penais, cit. n. 24, pp. 185-186; A garantia da motivação das decisões judiciais na Constituição de 1988, cit. n. 21, pp. 78-79.
} 
de levar em conta algum argumento ou elemento de prova trazido por qualquer das partes e que seja capaz de criar uma questão pertinente à causa. ${ }^{458}$

Diante da teoria das nulidades apresentada, não é possível dizer que a motivação que não atenda a um módulo mínimo seja inexistente, até por conta da premissa teórica segundo a qual o fundamento da nulidade não pode ser o vício, mas a sua consequência. A ideia de inexistência da motivação ${ }^{459}$ em casos nos quais não se atinja um modelo mínimo de justificação contraria também a ideia de validade prima facie dos atos processuais.

Por fim, entender pela inexistência da motivação por conta da violação a uma exigência ${ }^{460}$ de contornos pouco definíveis permite a manipulação da exigência, de modo que a proposta perde sua utliidade prática. Nesa perspectiva, só a completa omissão gráfica do discurso justificativo deve corresponder à ausência de motivação.

\subsection{Configuração e consequências da motivação nula}

A insuficiência da motivação decorre da inobservância do que exige o modelo de motivação delimitado no item 3.7. Assim, toda vez o juiz deixar de fundamentar a decisão até os limites expostos supra, item 3.7.4, a decisão poderá ser anulada.

Isso se deve, em primeiro lugar, ao fato de que a motivação só é capaz de desempenhar sua função legitimante da decisão judicial quando atingido o módulo de justificação descrito. Em segundo lugar, a motivação da decisão é o único modo pelo qual o juiz é capaz de se desincumbir do dever de atenção que lhe é imposto. ${ }^{461}$ Esse dever de atenção é consequência da concepção do contraditório como direito de influência e é correlato ao direito à consideração ínsito a essa concepção de contraditório.

\footnotetext{
${ }^{458}$ GOMES FILHO, Antonio Magalhães, A motivação das decisões penais, cit. $n$. 24, pp. 186-187; A garantia da motivação das decisões judiciais na Constituição de 1988, cit. n. 21 , pp. 79-80.

${ }^{459} \mathrm{E}$, consequentemente, da sentença, vez que se trata de um de seus componentes estruturais, conforme arts. 458, II, CPC e 381, III, CPP.

${ }^{460}$ A justificação "mínima" ou "suficiente" das decisões judiciais.

461 CABRAL, Antonio do Passo, Nulidades no processo moderno: contraditório, proteção da confiança e validade prima facie dos atos processuais, cit. n. 70, pp. 293-295.
} 
Assim, toda vez que o juiz não fundamentar suficientemente ${ }^{462}$ sua decisão, estará configurada um atipicidade relevante, que repercute na comunicação e, por isso, essa decisão poderá ser anulada.

${ }^{462} \mathrm{O}$ critério da suficiência da motivação é definido pelo modelo exposto no item 3.7.4. 


\section{Conclusão}

Esta dissertação se propôs a definir o que é necessário para que se possa considerar como motivada uma decisão e quais as consequências de eventuais vícios na motivação. Partiuse da definição da motivação como um discurso. Foi demonstrado, então que esse discurso tem a função de jusitificar racionalmente a decisão judicial e que a função do discurso condiciona sua estrutura e seu conteúdo.

Antes de analisar a estrutura e o conteúdo da motivação encarada como discurso justificativo, foi necessário entender as funções que a motivação desempenha em âmbitos mais amplos que os da decisão judicial. Nessa perspectiva, definiram-se as funções endoprocessuais e extraprocessuais da motivação.

Endoprocessualmente, a motivação possibilita, às partes, a impugnação das decisões judiciais e, permite aos juízes, a compreensão dos motivos de impugnação dessas decisões. Permite, ainda, a definição dos limites objetivos do julgado e é instrumental à função nomofilática e de unificação de jurisprudência desempenhada pelos tribunais de superposição.

Quanto à função extraprocessual da motivação, em primeiro lugar foi explorada a sua relação com outras normas constitucionais de conteúdo processual, para aferir o caráter instrumental da motivação às garantias de imparcialidade do juiz, de legalidade das decisões judiciais, do duplo grau de jurisdição e do contraditório. Após esse momento foi demonstrada que a motivação é o fator que confere legitimidade à atuação jurisdicional no Estado Democrático de Direito.

Ainda no âmbito da norma constitucional que impõe ao juiz o dever de fundamentar suas decisões, foi demonstrado que esta se estrutura sob a forma de regra, nos termos da teoria dos princípios de AlEXY, com a consequência de que os limites para a caracterização de uma decisão como motivada são rígidos. Isso significa que, não observado um modelo de justificação racional da decisão, essa seria reputada imotivada sem qualquer consideração por circunstâncias fáticas excepcionais. 
Passou-se, então, à construção de um modelo teórico de estrutura da motivação sob a ótica de suas funções contextual, endoprocessual e extraprocessual. Na construção desse modelo, foi demonstrado que a estrutura e o conteúdo da motivação no caso concreto dependem da interação de três modelos. O primeiro desses modelos, mínimo, corresponde à justificação adequada da fixação da norma, da determinação dos fatos, da qualificação jurídica e da declaração das consequências jurídicas que derivam da decisão, bem como dos nexos entre esses elementos da decisão. Exige, ainda, a enunciação dos critérios que fundaram as escolhas necessárias em cada um desses momentos da decisão judicial.

O segundo desses modelos é aquele determinado pelas partes em contraditório e é o mais importante deles, embora interaja com os demais. O terceiro desses modelos é delimitado pela linguagem e corresponde à existência de um limite de abstração em um jogo de linguagem como a motivação.

Esses critérios interagem da seguinte maneira: (i) toda vez que o contraditório não chegar a abranger algum dos elementos do primeiro grau de justificação, os nexos entre eles, ou a identificação dos critérios de escolha, o limite mínimo de motivação supera a delimitação do contraditório e impõe que o juiz fundamente a decisão sobre um ponto não debatido pelas partes (ii) toda vez que o contraditório superar os limites da linguagem, atingindo níveis de abstração nos quais a pergunta deixa de fazer sentido, o limite máximo reduz a delimitação do contraditório. O resultado dessa interação é o critério segundo o qual é possível dizer se uma decisão foi ou não fundamentada.

Definido esse critério, foram exploradas algumas situações práticas nas quais o critério comumente deixa de ser atendido para, ao fim, explorar as consequências dos vícios de motivação segundo uma teoria das nulidades dos atos processuais. Adotada à teoria comunicativa das nulidades processuais conclui-se que a motivação só será considerada inexistente em caso de omissão gráfica e que qualquer vício de fundamentação é uma atipicidade relevante que deve ser nulificada. 


\section{BIBLIOGRAFIA}

ALEXY, Robert, Direitos fundamentais no Estado constitucional democrático. Para a relação entre direitos do homem, direitos fundamentais, democracia e jurisdição constitucional, trad. port. de Heck, Luís Afonso in Revista Direito Administrativo, n. 217, Rio de Janeiro, 1999.

. Theorie der grundrecht, $5^{\mathrm{a}}$ ed., Berlin, Suhrkamp, 2006, trad. port. de Silva, Virgílio Afonso da, Teoria dos direitos fundamentais, São Paulo, Malheiros, 2008.

AlmadA, Roberto José Ferreira de, A garantia processual da publicidade, São Paulo, RT, 2006.

Ávila, Humberto, Teoria dos princípios: da definição à aplicação dos princípios jurídicos, São Paulo, Malheiros, 2010.

BADARó, Gustavo Henrique Righi Ivahy, Direito ao julgamento por juiz imparcial: como assegurar a imparcialidade objetiva do juiz nos sistemas em que não há juiz de garantias in Processo penal, Constituição e crítica, BonAto, Gilson (org.), Lumen Juris, Rio de Janeiro, 2011.

. Ônus da prova no processo penal, São Paulo, RT, 2003.

- Vícios de motivação da sentença penal: ausência de motivação, motivação contraditória, motivação implícita e motivação per relationem in Revista Brasileira de Ciências Criminais, v. 9, n. 38, 2002.

BARbosa MoreIRA, José Carlos, A motivação das decisões judiciais como garantia inerente ao Estado de Direito in Revista Brasileira de Direito Processual, v. 16, Rio de Janeiro, Forense, 1978.

Battaglio, Silvia, Indizio e prova indiziaria nel processo penale in Rivista italiana di diritto e procedura penale, Milano, Giuffrè, 1995.

BERGEAUd, Aurélie, Le droit à la preuve, Paris, LGDJ, 2010.

Botelho DE Mesquista, José Ignacio, Autoridade da coisa julgada e a imutabilidade da motivação da sentença, São Paulo, Salesianas, 1963.

Bueno, Cássio Scarpinella, Comentário ao artigo 458 in Código de Processo Civil Interpretado, MARCATO, Antonio Carlos (org.), São Paulo, Atlas, 2005.

Curso sistematizado de direito processual civil, v. 1, São Paulo, Saraiva, 2007.

. Direito, interpretação e norma jurídica: uma aproximação musical do direito in Revista de Processo, v. 28, n. 111, 2003. 
O modelo constitucional do direito processual civil: um paradigma necessário ao estudo do direito processual civil e suas aplicações in Revista de Processo, v. 33, n. 161, 2008.

CABral, Antonio do Passo, Nulidades no processo moderno: contraditório, proteção da confiança e validade prima facie dos atos processuais, $2^{\mathrm{a}}$ ed., Rio de Janeiro, Forense, 2010.

CADIET, Loïc; MeKki, Soraya Amrani; e NoRmand, Jacques, Théorie générale du procès, Paris, PUF, 2010

Calmon de Passos, José Joaquim, Esboço de uma teoria das nulidades aplicadas às nulidades processuais, Rio de Janeiro, Forense, 2009.

CÂMARA, Alexandre Freitas, A valoração da prova genética: está o juiz vinculado ao resultado do exame de ADN? in Provas: aspectos atuais do direito probatório, coord. NEVES, Daniel Amorim Assumpção, Rio de Janeiro, Forense, 2009.

CARmona, Carlos Alberto, Arbitragem e Processo: um comentário à Lei $n^{\circ}$ 9.307/96, $3^{\text {a }}$ ed., São Paulo, Atlas, 2009.

CARnelutti, Francesco, Lezioni sul processo penale, Roma, Ateneo, 1946.

CARrió, Genaro, Notas sobre Derecho y Lenguaje, Buenos Aires, Abeledo-Perrot, 1990.

Cintra, Antônio Carlos de Araújo; Grinover, Ada Pelegrini; DinAmarco, Cândido Rangel, Teoria Geral do Processo, 23 ${ }^{\mathrm{a}}$ ed., São Paulo, Malheiros, 2007.

CInTRA, Antônio Carlos de Araújo, Motivo e motivação do ato administrativo, São Paulo, RT, 1979.

Comoglio, Luigi Paulo, Lezione sul processo civile, Bologna, Il Mulino, 1995.

CORRÊA, Orlando de Assis, Sentença cível: elaboração e nulidades, $3^{\mathrm{a}}$ ed., Rio de Janeiro, Aide, 1985.

Dalbignat-Deharo, Gaëlle, Verité scientifique et verité judiciaire en droit privé, Paris, LGDJ, 2004.

Damasio, Antonio Rosa, Descartes' Error: Emotion, Reason, and the Human Brain, New York, Putnam, 1994, trad. port. de Vicente, Dora; Segurado, Georgina, O erro de Descartes: emoção, razão e o cérebro humano, São Paulo, Companhia das Letras 2006.

Damaska, Mirjan R., Rational and Irrational Proof Revisited, Faculty Scholarship Series. Paper 1577, http://digitalcommons.law.yale.edu/fss_papers/1577, 1997.

DE SAussure, Ferdinand, Cours de linguistique générale, $3^{\mathrm{a}}$ ed., Paris, Payot, 1964. 
DiAs, Ronaldo Brêtas de Carvalho, A fundamentação das decisões jurisdicionais no Estado Democrático de Direito in Processo e Constituição: estudos em homenagem ao professor José Carlos Barbosa Moreira, coord. FUX, Luiz; NERY JUNIOR, Nelson; e WAMBIER, Teresa Arruda Alvim, São Paulo, RT, 2006.

Dinamarco, Cândido Rangel, Instituições de Direito Processual Civil, v. 3, 4a ed., São Paulo Malheiros, 2004.

DÖHRING, Erich, Die erporschung des sachverhalts im prozess - beweiserhebung und beweiswürdigung, Berlin, Duncker \& Huimblot, 1964, trad. esp. de Banhaf, Tomás A., La investigación del estado de los hechos en el proceso - la prueba su práctica y apreciación, Buenos Aires, EJEA, 1972.

Dominioni, Oreste, In tema di nuova prova scientifica in Diritto penale e processo, n. 9, Milano, IPSOA, 2001.

DUTRA, Carlos Roberto de Alckmin, O controle abstrato de constitucionalidade sob o enfoque dos princípios processuais, Dissertação (Mestrado) - Faculdade de Direito de USP, São Paulo, 2010.

DWORKIN, Ronald, Justice for hedgehogs, Cambridge, Harvard University, 2011. . Taking rights seriously, Cambridge, Harvard University, 1977, trad. port. de Boeira, Nelson, Levando os direitos a sério, São Paulo, Martins Fontes, 2002.

FERnANDES, Antônio Scarance; GoMes Filho, Antônio Magalhães; Grinover, Ada Pellegrini, As nulidades no processo penal, 12a ed., São Paulo, RT, 2011.

Figueiredo Ferraz, Manuel Carlos de, Apontamentos sobre a noção ontológica do processo, São Paulo, Revista dos Tribunais, 1936.

FISS, Owen, Judicial Independence in Encyclopedia of the American Constitution, coord. LEVY, Leonard Williams; KARST Kenneth L.; e WINKLER, Adam, $2^{\mathrm{a}}$ ed., New York, Macmillan, 2000.

FRANCO, Fernão Borba, Aproximação entre processo judicial e administrativo: um enfoque sobre o procedimento e a motivação, Tese (Doutorado) - Faculdade de Direito de USP, São Paulo, 2006.

Garcia, André Almeida, Prova Civil, São Paulo, Saraiva, 2009.

GARCIA, Francisco de Assis, Da prova pericial no processo civil, Dissertação (Mestrado) Faculdade de Direito de USP, São Paulo, 2000.

GLADwell, Malcolm, Blink, New York, Back Bay Books, 2005. 
GOMES FILHO, Antonio Magalhães, A garantia da motivação das decisões judiciais na Constituição de 1988 in Processo penal e democracia: estudos em homenagem aos 20 anos da Constituição da República de 1988, Rio de Janeiro, Lumen Juris, 2009.

. A motivação das decisões judiciais na Constituição de 1988: funções políticas e processuais in Revista do Advogado v. 28, n. 99, 2008. . A motivação das decisões penais, São Paulo, RT, 2001.

. Breves anotações sobre a temática das provas no projeto de Código de Processo Penal (Projeto $n^{o}$ 156/2009 do Senado Federal) in Revista do Advogado n. 113, 2011.

. Excesso de motivação da pronúncia e modelo acusatório in Revista Brasileira de Ciências Criminais, v. 5, n. 19, 1997. . Notas sobre a terminologia da prova (reflexos no processo penal brasileiro) in Estudos em homenagem à Professora Ada Pellegrini Grinover, coord. MORAES, Mauricio Zanoide de e Yarshell, Flávio Luiz, São Paulo, DPJ, 2005.

. Provas in As Reformas no processo penal, MourA, Maria Thereza Rocha de Assis (org.), São Paulo, RT, 2008.

GRECO, Leonardo, Garantias fundamentais do processo: o processo justo in Novos Estudos Jurídicos, v. 7, n. 14, Itajaí, 2002.

GreCo FILHO, Vicente, Manual de processo penal, $7^{\mathrm{a}}$ ed., São Paulo, Saraiva, 2009.

GUERRA, Marcelo Lima, Notas sobre o dever constitucional de fundamentar as decisões judiciais (CF, art. 93, IX) in Processo e Constituição: estudos em homenagem ao professor José Carlos Barbosa Moreira, coord. FUX, Luiz; NERY JUNIOR, Nelson; e WAMBIER, Teresa Arruda Alvim, São Paulo, RT, 2006.

GuInchard, Serge et al, Droit processuel: droits fondamentaux du procès, $6^{\mathbf{a}}$ ed. Paris, Dalloz, 2011.

GUTHRIE, Chris; RaChlinski, Jeffrey J.; WISTRICH, Andrew J., Blinking on the Bench: How Judges Decide Cases in Cornell Law Review, v. 93, n. 1, 2007.

KAnE, Robert, The Oxford Handbook on Free Will, Oxford, Oxford University Press, 2005.

KELSEN, Hans, Reine rechtslehre, Franz Deuticke, Wien, 1960, trad. port. de Machado, João Baptista, Teoria Pura do Direito, São Paulo, Martins Fontes, 2003.

KNIJNIK, Danilo, A prova nos juízos cível, penal e tributário, Rio de Janeiro, Forense, 2007. 
- Os Standards do Convencimento Judicial: Paradigmas para o seu possível controle in Revista da Pós-Graduação da Faculdade de Direito da Universidade de São Paulo, v.3, n. 25, 2001.

LACERDA, Maria Francisca dos Santos e Zaganelli, Margareth Vetis, Livre apreciação da prova, ciência e raciocínio judicial: considerações sobre a 'cientifização' da prova no processo in Processo, verdade e justiça: estudos sobre a prova judicial, Rio de Janeiro, Lumen Juris, 2009.

LARENZ, Karl, Methodenlehre der rechtswissenschaft, Berlin, Springer, 1960, trad. port. de Lamego, José, Metodologia da ciência do direito, $3^{\text {a }}$ ed., Lisboa, Fundação Calouste Gulbenkian, 1997.

LECLERC, Olivier, Le juge et l'expert: contribution à l'étude des rapports entre le droit et la science, Paris, LGDJ, 2005.

LEITE, Lúcia Maria de Figueiredo Ferraz, A participação do cidadão na Administração Pública no direito brasileiro. O papel do Ministério Público, Dissertação Mestrado, Faculdade de Direito da Universidade de Lisboa, Lisboa, 2005.

LôBo, Paulo, Famílias, São Paulo, Saraiva, 2008.

Lucon, Paulo Henrique dos Santos, Embargos à execução, 2a ed., São Paulo, Saraiva, 2007.

Mahmoud, Mohamad Ale Hasan e MourA, Maria Thereza Rocha de Assis, Motivação da sentença condenatória e o habeas corpus perante o Superior Tribunal de Justiça in A renovação processual penal após a Constituição de 1988, Lumen Juris, Rio de Janeiro, 2009.

Manzano, Luís Fernando de Moraes, Prova pericial: admissibilidade e assunção da prova científica e técnica no processo brasileiro, São Paulo, Atlas, 2011.

MARQueS, José Frederico, Elementos de direito processual penal, v. 2, Campinas, Millennium, 2009.

MAYER, Lucie, Actes du procès et la théoria de l'acte juridique, Paris, IRJS, 2009.

Menezes Direito, Carlos Alberto, A decisão judicial in Revista da EMERJ, v. 3, n. 11, Rio de Janeiro, 2000.

Mitidiero, Daniel, Comentários ao Código de Processo Civil, t. 1, São Paulo, Memória Jurídica, 2004.

MotUlsky, Henri, Écrits: études et notes de procédure civile, 1973, 2a ed. Paris, Dalloz, 2010. 
MourA, Maria Theresa Rocha de Assis, A prova por indícios no processo penal, São Paulo, Saraiva, 1994.

OliveIRA, Pedro Miranda de, Princípios constitucionais do processo civil no âmbito recursal in Processo e Constituição: estudos em homenagem ao professor José Carlos Barbosa Moreira, coord. FuX, Luiz; NERY JUnIOR, Nelson; e WAMBIER, Teresa Arruda Alvim, São Paulo, RT, 2006.

Perelman, Chaïm e Olbrechts-Tyteca Lucie, Traité de l'argumentation: la nouvelle rhétorique, $5^{\mathrm{a}}$ ed., Bruxelles, Editions de l’Université de Bruxelles, 1988.

Pitombo, Sérgio Marco Moraes de, Pronúncia e o in dubio pro societate in Boletim do Instituto Manoel Pedro Pimentel, v. 15, n. 17, São Paulo, Centro de Estudos Penais e Criminológicos, 2001.

PORSCHER, Ralf, Ambiguity and Vagueness in Legal Interpretation in Oxford Handbook on Language and Law, SOLAN, Lawrence e TIERSMA, Peter (orgs.), Oxford, Oxford University Press, 2011.

Posner, Richard A., How judges think, Cambridge, Harvard University Press, 2008.

PozZA, Pedro Luiz, Sistemas de valoração da prova in Prova judiciária: estudos sobre o novo direito probatório, coord. KNIJNIK, Danilo, Porto Alegre, Livraria do Advogado, 2007.

QuiNE, Willard Van Orman, The Web of Belief, $2^{\mathrm{a}}$ ed., New York, Random House, 1978.

RAWLS, John, A Theory of Justice, Cambridge, Harvard University, 1999.

RECEnA Costa, Guilherme, Superior Tribunal de Justiça e recurso especial: análise da função e reconstrução dogmática, Dissertação (Mestrado) - Faculdade de Direito de USP, São Paulo, 2011.

ReICHelt, Luis Alberto, A prova no direito processual civil, Porto Alegre, Livraria do Advogado, 2009.

RocCO, Alfredo, La sentenza civile, Milano, Giuffrè, 1962.

ROUBIER, Paul, Droits subjectifs et situations juridiques, Paris, Dalloz, 1963.

Rumble, Wilfrid, American Legal Realism; Skepticism, Reform, and the Judicial Process, New York, Cornell University Press, 1968.

SALles, Carlos Alberto de, Transição paradigmática na prova processual civil, in Direito Civil e Processo: estudos em homenagem ao Professor Arruda Alvim, São Paulo, RT, 2007.

SAMPAIO, Rogério Marrone de Castro, Atuação do juiz no processo civil moderno, Tese (Doutorado) — Faculdade de Direito da USP, São Paulo, 2007 
SCAPINI, Nevio, La prova per indizi nel vigente sistema del processo penale, Milano, Giuffrè, 2001.

SouzA, Wilson Alves de, Sentença civil imotivada: caracterização da sentença civil imotivada no direito brasileiro, Salvador, Juspodivm, 2008.

TARUFFO, Michele, Conoscenza scientifica e decisione giudiziaria: profili generali in Decisione giudiziaria e verità scientifica, Milano, Giuffrè, 2005. . La motivazione della sentenza civile, Padova, CEDAM, 1975. . Verità e probabilità nella prova dei fatti in Revista de Processo, v. 54, São Paulo, RT, 2007.

TonINI, Paolo, La prova penale, $4^{\mathrm{a}}$ ed., Padova, CEDAM, 2000.

ToRnAGHI, Hélio, Curso de direito processual penal, v. 1. São Paulo, Saraiva, 1980.

TuCCI, José Rogério Cruz e, A motivação da sentença no processo civil, São Paulo, Saraiva, 1987.

Garantias constitucionais da publicidade dos atos processuais e da motivação das decisões no Projeto de CPC in Revista do Advogado, v. 32, n. 117, 2012.

TUCCI, Rogério Lauria, Direitos e garantias individuais no processo penal brasileiro, São Paulo, USP, Tese de titularidade, 1993.

VIEHWEG, Theodor, Topik und Jurisprudenz: Ein Beitrag zur rechtswissenschaftlichen Grundlagenforschung, trad. port. de Ferraz Junior, Tércio Sampaio, Tópica e jurisprudência, Distrito Federal Imprensa Nacional, 1979.

WAmbIER, Teresa Arruda Alvim, Omissão judicial e embargos de declaração, São Paulo, RT, 2005.

Wambier, Teresa Arruda Alvim, Nulidades do processo e da sentença, São Paulo, RT, 2004.

WAtson, Gary (org.), Free Will, Oxford, Oxford University Press, 2003.

WEBER, Max, Wirtschaft und Gesellschaft: Grundiss der versteheden Soziologie, trad. port. de Barbosa, Regis e Barbosa, Karen Elsabe, Economia e sociedade: fundamentos da sociologia compreensiva, v. 2, UnB, Brasília, 1999.

Wittgenstein, Ludwig, Philosophical investigations, Hoboken, Blackwell, 1953, trad. port. de Bruni, José Carlos, Investigações filosóficas, São Paulo, Nova Cultural, 1999.

. Tractatus logico-philosophicus, Routledge, London, 1922, trad. port. de Lourenço, M.S., Tratado lógico-filosófico, $3^{\mathrm{a}}$ ed., Fundação Calouste Gulbenkian, Lisboa, 2002. 
YARSHELL, Flávio Luiz, Antecipação da prova sem o requisito da urgência e direito autônomo à prova, São Paulo, Malheiros, 2009. 